\author{
UNIVERSIDADE DE SÃo PAULO \\ FACULDADE DE FILOSOFIA, LETRAS E CIÊNCIAS HUMANAS \\ DEPARTAMENTO DE LETRAS ORIENTAIS \\ PROGRAMA DE PÓS-GRADUAÇÃO EM LITERATURA E CULTURA RUSSA
}

\title{
SOBRE ISTO: \\ SÍNTESE DA POÉTICA DE MAIAKÓVSKI
}

Letícia Pedreira Mei

Dissertação apresentada ao Programa de Pósgraduação em Literatura e Cultura Russa, do Departamento de Letras Orientais da Faculdade de Filosofia, Letras e Ciências Humanas da Universidade de São Paulo, para a obtenção do título de Mestre em Letras.

Orientadora: Prof. ${ }^{a}$ Dr. ${ }^{a}$ Arlete Orlando Cavaliere Ruesch

SÃo PAULO

2015 
Ao meu maior amor, Laura, minha "Lolô", o coração de todas as coisas. 


\section{AGRADECIMENTOS}

À minha orientadora, Prof. a Arlete Orlando Cavaliere Ruesch, que me guiou desde os primeiros passos pelos caminhos da vanguarda russa, pelo entusiasmo e confiança no projeto.

Ao Prof. Mário Ramos Francisco Júnior, por suas sugestões e pelas palavras encorajadoras nos percalços da tradução de poesia.

À Prof. a Aurora Fornoni Bernardini, pelos comentários preciosos durante o exame de qualificação.

À querida Kátia Volkova Américo, por tudo: por ter aberto meus olhos e coração para os poemas longos de Maiakóvski, pela generosidade do cotejo e pelo incentivo constante.

À CAPES, pelo apoio durante o mestrado.

A Alcione Sanna, pela compreensão infinita.

A Alexandre, que conhece a força das palavras, meu amigo de tantos anos e para a vida inteira, agradeço pelas sugestões e pelo exemplo de tradutor e poeta.

A Eduardo, meu "companheiro de jornada", que viu nascer cada linha, cada verso, pelo carinho que transmite em cada olhar.

A meus pais, Júlio e Lúcia e a meu avô, Pedreira (in memoriam).

Agradeço, sobretudo, à minha filha Laura, моя любовь, que me dividiu com Maiakóvski. 
"A gente é escrito naquilo que escreve, traduzido naquilo que traduz." Henri Meschonnic 


\section{RESUMO}

MEI, L. M. "Sobre Isto: síntese da poética de Maiakóvski”. 2015. 236 f. Dissertação (Mestrado) - FFLCH - Universidade de São Paulo, São Paulo, 2015.

Palavras-chaves: Maiakóvski, literatura russa, poesia, tradução.

A dissertação é composta por duas partes que dialogam entre si. Na primeira, propõe-se uma tradução poética comentada do poema Pro Eto / Прo Эmo (Sobre Isto) (1923), de Vladímir Maiakóvski, diretamente do russo para o português brasileiro, inédita no Brasil. A segunda parte dedica-se à apresentação e análise dos elementos fundamentais do poema, seja no tocante às imagens e tema, seja nos aspectos formais de sua composição.

O poema, escrito entre dezembro de 1922 e fevereiro de 1923, possui 1.813 versos e foi publicado pela primeira vez na edição de estreia da revista $L E F$, criada e dirigida por Maiakóvski. A despeito da animosidade da crítica, muitos o consideraram a obra mais bem trabalhada do poeta, inclusive ele mesmo. O poema defende um novo amor condizente com a revolução e a nova sociedade, critica o individualismo da família tradicional e o filistinismo pequeno burguês.

A revolução reflete-se nas imagens e formas empregadas na composição que tornam Sobre Isto a súmula da poética de Maiakóvski. À luz das teorias formalistas de Ossip Brik, Nikolai Khardjiev, Vladímir Trenin, Roman Jakobson, Kristina Pomorska, e da própria concepção poética de Maiakóvski, o estudo pretende mostrar como som e sentido fundem-se para revolucionar a abordagem do amor na literatura e como a oficina poética de Maiakóvski se encontra plenamente realizada nesta obra. 


\begin{abstract}
MEI, L. M. “About this: synthesis of Mayakovsky’s poetics”. 2015. 236 f. Monograph (Master's degree) - FFLCH - University of São Paulo, São Paulo, 2015.
\end{abstract}

Keywords: Mayakovsky, Russian literature, poetry, translation.

The monograph is composed by two interconnected parts. The first one proposes a poetic annotated translation of the poem About This (1923), by Vladimir Mayakovsky, from Russian into Brazilian Portuguese, unpublished in Brazil yet. The aim of the second part is to present and analyze the fundamental elements of the poem, be it in terms of imagery and subject, be it concerning the formal compositional aspects.

The poem was writen between December 1922 and February 1923. It has 1,813 verses and was published for the first time in the premiere edition of the journal $L E F$, created and directed by Mayakovsky. Despite of the animosity of the critics, many considered it to be the most well developed work of the poet, including himself. The poem defends a new love befitting the revolution and the new society, it criticizes the individualism of the traditional family and the petty bourgeois philistinism.

The revolution is reflected in the imagery and compositional formal aspects employed, which makes About This a summary of Mayakovsky's poetics. In the light of the formalist theories of Ossip Brik, Nikolai Khardjiev, Vladimir Trenin, Roman Jakobson, Kristina Pomorska, and Mayakovsky's own poetic conception, the present study aims at demonstrating how sound and sense merge to revolutionize the approach of love in literature and how Mayakovsky's "poetical workshop" is completely accomplished in this oeuvre. 


\section{SUMÁRIO}

APRESENTAÇÃO

PARTE I. Tradução poética de Про Эmo (Sobre Isto), de Vladímir Maiakóvski

I.1. Tradução de poesia: uma utopia?

O jogo da tradução: perdas e ganhos na tradução de Sobre Isto ....... 20

I.2. Sobre Isto (tradução para o português, diretamente do russo) 24

I.3 Notas explicativas e comentários à tradução 86

PARTE II. Sobre Isto: uma poética síntese

II.1. Sobre Isto: a expressão do tema

II.2. Sobre Isto: a poética da expressão

REFERÊNCIAS BIBLIOGRÁFICAS

ANEXos 161

Anexo I: Про Эmo (texto original em russo) 162

Anexo II: Tabela de Transliteração do Russo para o Português 223

Anexo III: capa e folha de rosto da primeira edição de Sobre Isto 224

Anexo IV: foto de Lília Brik com a primeira edição de Sobre Isto 225

Anexo V: fotomontagens de Ródtchenko 226 


\section{APRESENTAÇ̃̃o}

O poeta e dramaturgo ${ }^{1}$ Vladímir Maiakóvski (1893-1930) dispensa apresentações junto ao público brasileiro. Tradutores e especialistas como Augusto e Haroldo de Campos, Boris Schnaiderman e Arlete Cavaliere tornaram populares no Brasil sua poesia, prosa e teatro. $\mathrm{O}$ trabalho deles foi fundamental para que hoje tenhamos acesso, em português, à tradução de obras de vários momentos de sua carreira literária e com uma miríade temática e poética que inibe qualquer simplificação.

O caráter político da obra de Maiakóvski teve ampla divulgação pelo regime soviético, sobretudo após a sua morte. Pasternak chegou a lamentar a "segunda morte" do poeta quando houve uma canonização e simplificação da sua obra reduzida ao viés político e empregada como instrumento do partido para consolidar seus ideais. Manipularam a sua imagem e a sua obra criando um mito sem contradições.

No prefácio de La Culture poétique de Maïakovski (A Cultura Poética de Maiakóvski), Gérard Conio afirma que o efeito mais claro dessa homenagem é ter feito Maiakóvski significar exatamente o contrário daquilo pelo qual lutou durante sua vida. ${ }^{2}$ Ele prossegue:

Toda a mitologia que se seguiu não tinha outro objetivo além de absorver a contradição que resultava dessa escamoteação. Era necessário refazer a história. Era necessário, em primeiro lugar, extirpar Maiakóvski de um círculo pernicioso. A primeira convicção será, portanto, a de que Maiakóvski nunca foi futurista. ${ }^{3}$

Ainda hoje perdura a associação imediata de Maiakóvski à literatura alinhada com o regime e essencialmente panfletária. Certamente, não se pode desvincular sua obra do seu tempo eminentemente político, o tempo da revolução. Revolução política, econômica, social que ele sempre buscou estender à arte. No entanto, não se pode cair na falácia de

\footnotetext{
${ }^{1}$ Sua poesia e teatro são bastante populares no Brasil, mas o mesmo não se pode dizer de suas outras áreas de atuação: o Maiakóvski pintor, desenhista, ilustrador, roteirista é menos conhecido pelo público.

${ }^{2}$ Khardjev, N. Trenine, V. La culture poétique de Maïakovski. Lausanne : L'Age d'Homme, 1982. Prefácio de G. Conio, p. 9.

${ }^{3}$ Idem, p. 11 .
} 
um Maiakóvski linear e monódico. Observadas as devidas diferenças, como Dostoiévski, ele é multíssono, polifônico ${ }^{4}$, complexo e muitos dos seus poemas transbordam um lirismo marcante na literatura russa.

A pesquisa pretende, pois, aumentar a divulgação em língua portuguesa de um Maiakóvski diferente daquele exaltado pelo regime. Além de suas obras-primas de cunho político, o poeta eternizou em seus versos temas humanos fundamentais e universais que transcendem qualquer período histórico.

Nosso primeiro contato mais profundo com o escritor deu-se durante a graduação com o estudo concomitante de seu teatro e de sua poesia. Enriqueceu-se, assim, uma imagem que também carregávamos monolítica e desenvolveu-se uma nova visão que contempla o escritor na riqueza de suas contradições, na eloquência tanto dos seus encômios quanto das suas críticas, na exacerbação do seu amor e na exposição de suas (des)crenças.

Após flertar com o texto da sua peça de estreia na dramaturgia russa Vladímir Maiakóvski, uma Tragédia (1913), descobrimos o longo poema Sobre Isto (1923), uma obra mais madura, cuja tradução integral diretamente do russo para a língua portuguesa, inédita no Brasil, foi o coração do mestrado. Num primeiro momento, o que chamou a atenção foi uma relação com Dostoiévski ${ }^{5}$ e com o motivo do duplo, temas que estudáramos na iniciação científica ${ }^{6}$ durante a graduação. Paulatinamente, a pesquisa mostrou-nos muitos outros elementos relevantes e essas relações passaram para o segundo plano.

Por que exatamente Sobre Isto? Khardjiev e Trenin ${ }^{7}$ apontaram a obra como uma enciclopédia do poeta, uma compilação dos elementos fundamentais do seu método poético. Além da importância de ampliar a recepção de um poeta tão conhecido e do qual ainda há tanto a traduzir no Brasil, propomos a análise de Sobre Isto como uma espécie de síntese da poética de Maiakóvski, em que os elementos cardeais da sua composição e do seu arcabouço ideológico são trabalhados em seu grau máximo para lutar contra o cotidiano e para promover o eixo principal de uma sociedade que se quer igualitária: o

\footnotetext{
${ }^{4}$ Ele mesmo define seu encargo no artigo "Nosso trabalho vocabular", de 1923: "Maiakóvski. Experimento de ritmo polifônico em poema de vasto âmbito social." Cf. Schnaiderman, B. , A Poética de Maiakóvski. São Paulo: Perspectiva, 1971, p. 222.

${ }^{5}$ A relação imediata dá-se entre o título do poema e Crime e Castigo, que comentamos na primeira nota à tradução na segunda parte desta dissertação.

${ }^{6} \mathrm{Na}$ iniciação científica analisamos a novela $O$ Duplo de Dostoiévski, na monografia " $O$ Duplo: gênese e desenvolvimento do herói polifônico na obra de Dostoiévski", sob a orientação do Prof. Dr. Marcus Vinícius Mazzari, do Departamento de Teoria Literária e Literatura Comparada. Comentários complementares sobre as relações serão fornecidos nas notas que seguem a tradução.

${ }^{7}$ Khardjiev, N., Trenine, V. "Le travail de Maïakovski sur le poème De Ceci". In : Khardjiev, N. , Trenine, V. K,. op. cit., p. 234.
} 
amor universal que transcende as barreiras individualistas da família tradicional. Todas as criações de Maiakóvski são profundamente ancoradas no seu momento histórico. Algumas ficaram datadas com o passar do tempo, mas Sobre Isto não poderia ser mais atual.

Apesar das críticas ferozes contra o lirismo da obra e contra o evidente caráter autobiográfico, o próprio poeta a considerava uma das mais importantes e bem elaboradas da sua carreira literária. Na autobiografia "Eu mesmo", Maiakóvski esboça o projeto: "Projetado: sobre o amor. Um poema colossal. Termino-o no ano que vem." E anuncia na rubrica "1923": "Escrevi 'Sobre isto'. O cotidiano de todos, segundo motivos pessoais." $"$.

Do ponto de vista de sua arquitetura, o poema narrativo tem 1.813 versos sem métrica definida, como era comum nos movimentos de vanguarda. Antes, domina a polimetria sempre guiada pela manutenção do ritmo e pela garantia da sonoridade expressiva. Divide-se em uma espécie de prólogo, dois capítulos e um epílogo, subdivididos em seções.

O poema foi publicado pela primeira vez em 29 de março de 1923 no primeiro número da revista LEF (Levyi front iskusstv / Левыіü фронт искусств, Frente de Esquerda das Artes), criada e dirigida pelo próprio Maiakóvski. Há três manuscritos diversos do poema conservados por Lília Brik. Em junho do mesmo ano, foi publicado separadamente em volume ilustrado com as fotomontagens de Ródtchenko, ressaltando, assim, a correlação entre palavra poética e imagem artística ${ }^{9}$.

Maiakóvski começou a escrevê-lo no final de dezembro de 1922. Após a primeira redação, realizou diversas correções e acréscimos significativos e, em seguida, concluiu a versão final. A data de conclusão atribuída a esta versão é 11 de fevereiro de 1923, quando o poeta decidiu reescrevê-lo fazendo pequenas correções, porém conservando a data.

A elaboração do poema deu-se durante dois meses de isolamento de Maiakóvski em seu apartamento na passagem Lubiánski. Apesar do evidente traço autobiográfico, sabe-se que a separação de Lília Brik não foi o único ponto de partida do projeto. Seus escritos deixam claro, bem como a leitura atenta de seus poemas anteriores a 22 , em que já se observam metáforas e símbolos presentes no poema Sobre Isto.

\footnotetext{
${ }^{8}$ Schnaiderman, B., op. cit., p. 101.

${ }^{9}$ As reproduções das fotomontagens encontram-se nos anexos da dissertação.
} 
Não se pode reduzir a obra à mera confissão pessoal, mas uma primeira leitura já mostra a estreita relação entre autor e biografia tão bem colocada em $A$ geração que esbanjou seus poetas, de Roman Jakobson. Entretanto, Maiakóvski empreendeu diversas mudanças no poema justamente para conferir-lhe um caráter universal, que transcendesse o aspecto individualista da lírica amorosa. Seu projeto consistia em esclarecer quem era o novo homem, sua moral, seus sentimentos e sua vida. Sobre Isto alinha-se, então, a muitas outras obras fundamentais do poeta e dramaturgo, como a peça $O$ Percevejo (1928), na qual Maiakóvski volta-se contra os novos ricos oriundos da NEP, emblema do egoísmo e da vulgaridade.

Partindo de suas primeiras experiências no cubofuturismo, passando por seus longos poemas, como Nuvem de calças e $O$ Homem $^{10}$, ambas de 1916, obras pré-revolucionárias intensas e otimistas quanto à revolução, em Sobre Isto (1923) encontramos um Maiakóvski angustiado e decepcionado com o cotidiano banal que insiste em instalar-se. Maiakóvski envolveu-se visceralmente com as propostas da revolução e com a concepção e construção de um mundo novo, em todos os âmbitos. Talvez por isso mesmo, ele tenha sofrido tanto com as contradições da vida pós-revolução.

Mal compreendido pela crítica soviética, avessa a qualquer esboço de lirismo e subjetividade, Maiakóvski foi bombardeado de recriminações. Durante um debate acerca do poema ele defende-se:

Aqui diz-se que no meu poema não se deve colher uma mensagem geral. Em primeiro lugar li apenas trechos, mas já nesses trechos citados, há um único eixo importante: $o$ viver cotidiano $^{11}$. Aquele viver em que nada muda, aquele viver que se manifesta hoje como o nosso pior inimigo e que faz de nós filisteus. ${ }^{12}$

Segundo Bengt Jangfeldt ${ }^{13}$, especialista e biógrafo de Maiakóvski, os primeiros a ouvir a leitura do poema foram Lunatchárski e Chklóvski, ambos positivamente impressionados. No entanto, as primeiras dissidências surgiram logo após a publicação na $L E F$, pois a revista militava por uma estética nova construtivista, com fins práticos e didáticos.

\footnotetext{
${ }^{10}$ A data de $O$ Homem é controversa. Comentaremos mais a respeito na Parte II.

${ }^{11} \mathrm{O}$ termo russo, de difícil tradução, é byt / быт.

${ }^{12}$ Maiakóvski, Di questo. Prefácio de Anna Zorini. Firenza: Passagli, 2009, p. 15. Grifo meu.

${ }^{13}$ Jangfeldt, B. La vie en jeu. Paris : Albin Michel, 2010, p. 256.
} 
No segundo número da revista foi publicada a crítica de Nikolai Tchouják ${ }^{14}$ :

Um romance sentimental... capaz de fazer chorar as colegiais... Mas nós que conhecemos muitos outros aspectos de Maiakóvski, não nos comovemos de modo algum com isso em 1923.

Todo esse mistério reside no byt. O byt conduz a dança. Minha casa. Ela, cercada de seus amigos e criados. [...] Ela dança o one-step. [...] E ele escuta escondido atrás da porta, corre com a sua genialidade de um pequeno burguês a outro, fala sobre arte com eles, lamenta a sua sorte [...] e chega à conclusão: "Não há saída!” [...]

No fim deste poema, fala-se de uma solução. Esta solução é que no futuro, tudo será diferente, que haverá uma espécie de vida imensa. [...] Para mim, parece-me que esta fé nasce do desespero pelo fato de que "não há saída". [...] Não é uma solução, mas uma situação desesperada.

O problema para Tchouják era colocar no futuro a esperança da mudança, isso traduzia a descrença na revolução: "Nós não precisamos estender os braços em direção à eternidade (que na prática é sinônimo de passado), mas dos sólidos canteiros de trabalho do hoje..."

Justificada a escolha e apresentada a obra, passemos à estrutura da dissertação. O estudo compõe-se de duas partes principais. A primeira propõe, primeiramente, uma introdução à tradução. Nela apresentamos algumas reflexões acerca das teorias tradutórias norteadoras, expomos o método de trabalho, os materiais utilizados e apontamos os principais problemas e dificuldades na tradução específica deste poema. A essa introdução segue-se uma tradução poética integral do poema diretamente do russo para o português brasileiro. Essa parte conclui-se com as notas explicativas e comentários à tradução, que consistem nas soluções, alternativas de tradução, dados históricos, geográficos e biográficos. Em suma, tudo o que contribui para a compreensão do poema e da tradução aqui apresentada.

Na parte II, abordaremos a arquitetura de Sobre Isto: sua macroestrutura, seu conteúdo em relação aos ideais do poeta, imagens, sua estrutura rítmica e seus elementos sonoros,

\footnotetext{
${ }^{14}$ Apud Jangfeldt, B., op. cit., p. 260. Grifos do original em francês.

${ }^{15}$ Idem, ibidem. Grifos do original.
} 
a relação entre som e sentido - fundamental em Maiakóvski -, apoiando-nos em exemplos do poema e nas teorias de Ossip Brik, Roman Jakobson, Nikolai Khardjiev, Vladímir Trenin, Benedikt Livichits, Kristina Pomorska, do próprio Maiakóvski, dentre outros.

Assim, pretendemos demonstrar que os elementos essenciais da poética revolucionária de Maiakóvski concentram-se, todos muito bem trabalhados, em Sobre Isto, sob o encargo social de uma revolução também no plano das relações humanas.

Estudar a obra de Maiakóvski é um projeto para a vida inteira. Nesta longa jornada, este é apenas o primeiro passo... 
PARTE I:

Tradução Pó́tica de Птo ЭTo (Sobre ISTo), DE VladíMIR MaIAKóvSKi

\section{1. Tradução de poesia: uma utopia?}

Traduzir é sempre um desafio. A tradução de poesia desperta ainda mais incertezas. Nesta seção convidamos à reflexão acerca dos desafios inerentes à tradução de poesia e, mais especificamente, do poema Sobre Isto. Pretendemos apontar os cuidados e estratégias gerais adotadas com o intuito de reproduzir, em português, os mesmos efeitos linguísticos e sonoros que fundamentam o seu estilo, notadamente a rima, recurso fundamental para a manutenção do ritmo, elemento essencial da sua obra.

Como Haroldo de Campos ${ }^{16}$, consideramos tradução, acima de tudo, uma leitura crítica, portanto, debruçar-se sobre seu poema é desvendar características fulcrais da poética de um dos grandes poetas do século XX, do qual ainda há tanto a traduzir no Brasil.

Para Jakobson, comunicação é tradução: o significado de um signo linguístico é sua tradução por outro signo ${ }^{17}$ e "toda experiência cognitiva pode ser traduzida e classificada em qualquer língua existente" ${ }^{18}$. Na tradução interlingual (interpretação de signos verbais por meio de alguma outra língua, ou tradução propriamente dita) não há comumente equivalência completa entre as unidades de código e "onde houver uma deficiência, a terminologia poderá ser modificada por empréstimos, calços, neologismos, transferências semânticas e, finalmente, por circunlóquios”19.

\footnotetext{
${ }^{16}$ Campos, H. de. "Da tradução como criação e como crítica". In: Metalinguagem e outras metas. São Paulo: Perspectiva, 2010, p. 32.

${ }^{17}$ Jakobson, R. "Aspectos Linguísticos da Tradução". In: Linguística e Comunicação. São Paulo: Cultrix, 2003 , p. 42.

${ }^{18}$ Idem, p. 44.

${ }^{19}$ Idem, ibidem.
} 
A tradução é um processo inacabado sempre sujeito à reformulação e continuidade. O texto é vivo, movente, portanto semeador de milhares de interpretações e traduções. A esse respeito, recorremos à citação de Mário Laranjeira: tradução é “como a escritura de uma leitura do poema" ${ }^{20}$. Ora, uma leitura dentre as inúmeras possíveis.

A tradução é, por definição, criativa e não se restringe à busca de equivalentes. Para Boris Schnaiderman não existe, entre uma língua e outra, coincidência exata entre o que ele chama de "faixas semânticas"21. Uma das regras tácitas da "boa tradução", segundo o russista, é a atenção especial que se dá a elas no processo tradutório.

A preocupação com a recepção e a reprodução do mesmo efeito do original não é recente. O parâmetro clássico sempre foi o do privilégio do texto de partida, da preponderância do autor sobre o tradutor e do respeito absoluto à noção de equivalência e de competência linguística, que não são totalmente descartáveis. São necessárias, mas não suficientes, eis o problema.

Num segundo momento dos Estudos da Tradução ganha ênfase um olhar prospectivo, ou seja, voltado para a cultura receptora do texto. O tradutor deixa de ser, então, um sujeito isento no processo de intermediação e o bom conhecimento da língua torna-se insuficiente. Os elementos culturais entram em cena e o tradutor deve ser capaz de contemplá-los no processo tradutório, visando à recepção do texto. Tradução torna-se algo mais abrangente. Uma vez que a noção de transferência cultural atinge o processo de tradução como um todo, a discussão alcança, sob essa ótica, uma camada mais profunda que transcende a tipologia textual e lança novos desafios ao tradutor.

O tradutor é um mediador cultural que lida com a representação da realidade e não com a realidade. Não se pode falar, então, de estabilidade e perenidade absolutas. A tradução pode ser vista como um comentário pessoal de uma leitura de um texto. Por conseguinte, é importante refletir acerca da posição assumida pelo tradutor e do lugar reservado ao leitor. Toda tradução encerra uma posição ideológica, apresenta a voz do tradutor e os sentidos do texto se (re)constroem na interação da leitura.

Atualmente, considera-se que o referente constitui-se a partir de "um processo (não verbal) de cognição, de construção e de ordenação do universo" ${ }^{22}$, no interior do discurso. Consequentemente, a construção do sentido em tradução desloca-se da noção

\footnotetext{
${ }^{20}$ Laranjeira, M. Poética da Tradução. São Paulo: Edusp, 2003, p. 40.

${ }^{21}$ Schnaiderman, B. Tradução, ato desmedido. São Paulo: Perspectiva, 2011, p. 26.

${ }^{22}$ Azenha, J. "Linguística textual e tradução: redefinindo o conceito de marca cultural”. TradTerm, 12, São Paulo, 2006, p. 17.
} 
do referente para a atividade da referenciação, entendida como uma "gama de recursos" a que recorrem o produtor e o leitor do texto, para "construir, desconstruir e reconstruir cadeias significativas num processo de interação" 23 .

Ainda, segundo Azenha ${ }^{24}$, a coerência envolve não apenas a noção de lógica e estrutura textual, mas também um conhecimento acerca do mundo, ou seja, ela não é intrínseca ao texto, mas se constrói em um processo de interação com o usuário da língua, leitor ou tradutor. O texto transcende, assim, o status de mero depositário de sentidos predefinidos e se renova através de uma rede de associações concretizadas no ato da leitura. Isso torna o texto singular, pois a cada leitura novas relações de dependência e associações são estabelecidas. Tal renovação constante baseada na experiência singular de cada leitura do texto norteia a visão de Azenha acerca de marca cultural.

Azenha $^{25}$ mostra-nos que tradução é sempre da mesma natureza independentemente do tipo do texto de partida. No entanto, acredita na diferença de grau entre as traduções de textos de especialidade e literários. Assim como no tocante ao primeiro gênero houve uma mudança de olhar, no que tange os textos literários também. A perspectiva estática é suplantada por uma rede dinâmica. Respeitado esse alicerce comum, deve-se observar a especificidade do discurso literário em que a dimensão criativa sustenta o ponto de vista sobre o mundo. Recursos linguísticos e não-linguísticos são empregados para dar vida aos personagens e situações e também a um certo ponto de vista, uma ideologia acerca do mundo. As marcas culturais ancoram o texto e "evaporam" pela tessitura discursiva. O olhar do tradutor deve ser, então, retrospectivo, para identificar a dimensão criativa, sem, no entanto, desconsiderar a sua recepção. Nesse ponto a tradução é vista como um todo: o ponto de partida é sempre um objetivo, uma função para o texto traduzido. Chega-se, pois, a um estrato comum em que a noção de transferência cultural cria um "espaço da tradução e do traduzir como um todo"26.

Paulo Bezerra, professor e tradutor da literatura russa, afirma que não se traduz língua mas linguagem ${ }^{27}$. Ele também incorpora a questão cultural à sua visão de tradução, pois para ele "a tradução é um diálogo de culturas, uma interação do meu com o do outro". ${ }^{28}$ Ele retoma Henri Meschonnic afirmando que a tradução de ficção não opera

\footnotetext{
${ }^{23}$ Idem, ibidem.

${ }^{24}$ Idem, p. 19.

${ }^{25}$ Azenha, J. "Transferência cultural em tradução: contextualização, desdobramentos, desafios".

TradTerm, 16, São Paulo, 2010, p. 59.

${ }^{26}$ Idem, ibidem.

${ }^{27}$ Bezerra, P. "Tradução e criação". Linha d'Água, 25(2), São Paulo, 2012, p. 25.

${ }^{28}$ Idem, p. 19.
} 
com significados, mas com sentidos. ${ }^{29}$ Defende a noção da "dessemelhança do semelhante" e afirma que semelhança literal é diferente de semelhança artística. Ele também defende a visão da obra em movimento.

Acreditamos que não há diferenças de mérito na tradução dos diversos tipos de texto, já que a noção de gênero textual não é estanque. Preferimos pensar em um continuиm entre eles e em características mais ou menos marcadas de um ou outro gênero. Segundo Azenha ${ }^{30}$, os textos de especialidade constituem um complexo heterogêneo, de contornos imprecisos em que evoluem permanentemente, num continuum, de um gênero textual para outro.

É inegável, entretanto, que há especificidades inerentes a cada texto a ser traduzido. Segundo Lacoue-Labarthe "O poema é solitário [...]: um poema só é efetivamente poema na medida em que é absolutamente singular" ${ }^{31}$. Laranjeira argumenta que "cada tradução é tão única quanto o poema original" 32 . Cada texto estabelece um diálogo sui generis com o leitor e, consequentemente, com o tradutor/leitor. Isso independe do gênero: um poema de Maiakóvski é diferente de um poema de Baudelaire, e suas traduções apresentam desafios específicos, embora ambos compartilhem elementos característicos do gênero poesia.

A tradução de poesia é envolta em alguns mitos. Poesia é traduzível? A tradução está à altura do original? O tradutor é subjugado pelo autor? ${ }^{33}$ É preciso ser poeta para traduzir poesia? Concordamos que não há superioridade intrínseca na tradução de um ou outro gênero textual, mas sustentamos que há especificidades a serem contempladas. Muitos interpretaram como inexorável a afirmação “a poesia é, por definição, intraduzível" de Jakobson. Laranjeira ${ }^{34}$ crê, e concordamos com ele, que Jakobson apenas deu outro nome à tradução poética, que, aliás, ele mesmo pratica: transposição criativa, expressão que ressalta a especificidade da tradução do gênero, pois "em poesia, as equações verbais são elevadas à categoria de princípio construtivo do texto.”35

\footnotetext{
${ }^{29}$ Meschonnic, H. Poética do traduzir. São Paulo, Perspectiva, 2010, p. 57 apud Bezerra, p. 17.

${ }^{30}$ Azenha, J., op. cit., p. 49.

${ }^{31}$ Lacoue-Labarthe, P., La Poésie comme expérience, p. 63, apud Laranjeira, op. cit, p. 38.

${ }^{32}$ Laranjeira, M., op.cit., p. 39.

33 As duas últimas questões poderiam ser aplicadas a qualquer outro texto a ser traduzido, não se restringindo à poesia. Entretanto, nesse gênero parece-nos que elas assumem um peso maior para o senso comum.

${ }^{34}$ Laranjeira, M., op. cit., p. 28.

35 Jakobson, M., op. cit, , p. 47.
} 
Leon Robel diz que a poesia é o mais traduzível dos textos, a ideia de intradutibilidade seria uma projeção da utopia romântica do indivíduo versus mundo ${ }^{36}$. Como o poema permite inúmeras leituras, inúmeras são as possibilidades de tradução. A intradutibilidade é, pois, pontual e não exclusiva da poesia. Aspectos culturais ou linguísticos podem ser intraduzíveis a princípio, mas a criatividade e o repertório linguístico do tradutor são capazes de superá-los de alguma maneira.

Boris Schnaiderman diz em Tradução, ato desmedido que "precisamos traduzir justamente aquilo que se considera impossível na língua de chegada" ${ }^{37}$ em consonância com a visão de Haroldo de Campos e Paulo Rónai. O que permite a tradução para ele é “o arrojo, a ousadia, os voos da imaginação [...] tão necessários na tradução como a fidelidade ao original, ou melhor, a verdadeira fidelidade só se obtém com esta dose de liberdade no trato com os textos." 38 É "a relação entre o semântico e o poético, este jogo de imaginação e fantasia" que constitui "a pedra de toque de uma tradução"39.

Mário Laranjeira fala em "graus variáveis de tradutibilidade" 40 e defende a recriação na "língua-cultura de chegada" da "significância do poema original, preservando assim a sua poeticidade específica." ${ }^{41}$ Para Laranjeira o texto é múltiplo, total, forma e fundo entrelaçam-se, "a poeticidade do texto reside numa relação geradora de sentidos"42. Para ele "traduzir o poema é trabalhar a língua de chegada para se obter uma relação semelhante em termos de significantes que obterá uma significância correlata à do poema original" $"$. Mais adiante afirma que "o bom tradutor é o que produz um bom texto, um bom poema, autônomo, como objeto que, uma vez criado, passa a valer e a viver por si mesmo na relação que gera com seu leitor." 44

Paulo Henriques Britto afirma que a poesia articula vários níveis da linguagem: semântico, sintático, fonético e rítmico, dentre outros, e que o tradutor de poesia deve recriar com os recursos da língua alvo, os efeitos de forma e conteúdo do original. ${ }^{45}$

\footnotetext{
${ }^{36}$ Robel, L. "Transformer. Traduire." Revista Change, n. ${ }^{\circ} 14$, apud Laranjeira, op. cit., p. 14.

${ }^{37}$ Schnaiderman, B., op. cit., p 22.

${ }^{38}$ Idem, p. 18

${ }^{39}$ Idem, p. 34

${ }^{40}$ Laranjeira, M., op. cit., p. 15.

${ }^{41}$ Idem, p. 24.

${ }^{42}$ Idem, p. 20.

${ }^{43}$ Idem, p. 30.

${ }^{44}$ Idem, p. 38.

${ }^{45}$ Brito, P. H. "Para uma avaliação mais objetiva das traduções de poesia". In: Krause, G. B. As margens da tradução. Rio de Janeiro: FAPERJ/Caetés/UERJ, 2002, p.17.
} 
Quanto à polêmica "original versus tradução", acreditamos que nenhum texto é definitivo. Brito ${ }^{46}$ afirma que todo texto é uma espécie de tradução de outros textos. A noção de originalidade absoluta baseia-se no pressuposto anacrônico de um autorindivíduo autônomo e consciente. Ele diferencia, ainda, qualitativamente, os processos de escritura e tradução. Esta evita a autonomização excessiva, buscando amiúde o cotejo com o original, ou seja, a fonte exerce certo controle sobre a tradução.

Enfim, o mais controverso mito em torno da tradução poética: é preciso ser poeta para traduzir poesia? Para Laranjeira ${ }^{47}$ é necessário ser potencialmente poeta, quer dizer, ter as habilidades de um, mas não necessariamente ser reconhecido socialmente como um. O professor Paulo Vizioli, citado por Laranjeira ${ }^{48}$, defende a necessidade de um profundo conhecimento das línguas e de "gosto pelo verso". Acreditamos que o tradutor de poesia precisa ter um bom domínio das línguas de partida e chegada, mas, sobretudo, um profundo conhecimento da poética do autor traduzido e um vasto repertório de formas poéticas na língua alvo. Bezerra citando Pasternak diz que "cada avanço diário pelo texto coloca o tradutor em situações vividas pelo autor. Dia após dia ele reproduz os movimentos um dia efetuados pelo grande protótipo"49.

Foi justamente esse caminho original que tentamos percorrer durante o processo de tradução de Sobre Isto. Caminho cujo roteiro exporemos a seguir.

\section{O jogo da tradução: perdas e ganhos na tradução de Sobre Isto}

Trabalhamos com o apoio de quatro traduções: uma italiana, uma francesa e duas inglesas, cada uma com uma proposta diferente e com vantagens e desvantagens. O cotejo delas foi útil para elucidar passagens de sentido obscuro e para inspirar algumas soluções. Além das traduções, utilizamos a gravação de uma leitura do poema feita por Lília Brik que nos ajudava a captar a sonoridade do texto ${ }^{50}$.

\footnotetext{
46 Brito, P. H. "Tradução e criação". Maria Lúcia Vasconcellos (org.). Cadernos de Tradução n. IV. Florianópolis: UFSC, 1999, p 3.

${ }^{47}$ Laranjeira, M., op. cit., p. 38.

${ }^{48}$ Idem, p. 37.

${ }^{49}$ Pasternak, B. Seleta em 2 tomos. t. 2. Moscou: Ed. Khudójestvennaya Literatura, 1985, p. 316 apud Bezerra, p. 21.

50 Áudio disponível em http://my.mail.ru/mail/arkadij-khait/video/16540/16544.html, acesso em 26 de janeiro de 2015 .
} 
Para organizar a tradução, aproveitamos a própria arquitetura do poema, dividido em três partes principais subdivididas em pequenos capítulos ou seções. Traduzimos cada seção como um bloco poético, ou seja, dedicávamo-nos a uma seção e seguíamos as mesmas etapas até que a sua tradução poética estivesse pronta. Somente depois continuávamos. Posteriormente foram realizadas inúmeras revisões e modificações e cada releitura enseja novas soluções.

O método de trabalho consistia numa primeira imersão sonora e, em seguida, no esboço da tradução, já tentando, quando possível, conferir os traços poéticos mais evidentes. Em seguida, passávamos à releitura atenta do original russo, marcando os aspectos sonoros relevantes: rimas, assonâncias, aliterações. Nós os ressaltávamos no texto traduzido e trabalhávamos na sua recuperação, preferencialmente no mesmo ponto do original. Já no tratamento das assonâncias e aliterações trabalhamos com um pouco mais de liberdade. Como o som é essencial nos poemas de Maiakóvski, às vezes sacrificamos a fidelidade absoluta ao significado da palavra para ganhar em sonoridade.

Maiakóvski privilegiava as rimas inesperadas e a sonoridade áspera, justamente para reforçar a relação da forma e do conteúdo: “A rima amarra as linhas, por isto o seu material deve ser ainda mais forte que o material utilizado nas demais linhas." 51 A ideia é aprofundada por Trenin e Khardjiev ${ }^{52}$ : “A rima de Maiakóvski é sempre portadora de

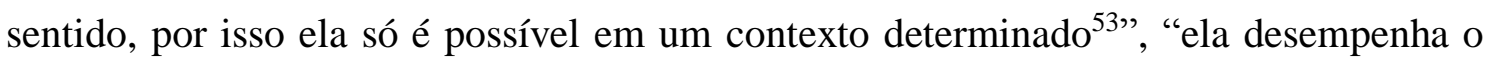
papel original de reforçar o sentido" ${ }^{\$ 4}$. Esta foi uma das dificuldades enfrentadas durante a tradução: não bastava recuperar as rimas, eles deveriam, na medida do possível, associar os mesmos sentidos. Assim, buscamos sempre manter a rima entre os mesmos termos. Comentários mais aprofundados e exemplos serão dados na próxima parte.

Além dos aspectos sonoros, há um outro crucial na poética de Maiakóvski: os neologismos. Durante a tradução, a principal dificuldade era a sua identificação inicial. Frequentemente surgia a dúvida: trata-se mesmo de um neologismo em russo? Confirmada a hipótese vinha a parte criativa do trabalho, geralmente com as bases do neologismo russo, tentávamos criar seus equivalentes em português. Os comentários após a tradução explicam em detalhes as escolhas e processos de formação de cada um deles.

\footnotetext{
51 Idem, p. 192.

${ }^{52}$ Khardjiev, N. "Les rimes répétées”. In: Khardjiev, N. Trenine, V., op. cit., p. 292.

${ }^{53}$ Idem, p. 292.

${ }^{54}$ Khardjiev, N. “L’évolution de la rime de Maïakovski”. In: Khardjiev, N. Trenine, V., op. cit., p. 269.
} 
Outros desafios específicos do poeta são a irregularidade da pontuação, a instabilidade dos aspectos verbais e a economia verbal. Tentamos respeitar o original e não o maquiar ou organizar à nossa maneira. Abordaremos a linguagem e os elementos rítmicos e sonoros à luz de exemplos e embasamentos teóricos na próxima parte da dissertação.

Também foi primordial na nossa tradução a tentativa de recuperar a oralidade da linguagem maiakovskiana. Impera a polimetria, mas tentamos, quando possível, privilegiar as redondilhas e os octossílabos que caracterizam a fala e as composições populares. Entretanto, há versos longos que recuperamos com decassílabos, dodecassílabos ou mais. Evitamos o vocabulário rebuscado e não hesitamos em empregar palavras do cotidiano. Fugimos, quando possível, das inversões sintáticas que conferem um tom pesado à tradução em português.

Uma dificuldade para manter o registro informal, foi a escolha do pronome de tratamento empregado: "tu" ou "você"? O primeiro, apesar de ser usado em algumas regiões do Brasil, travestiria o poema de uma solenidade ou regionalismo que ele não tem. O último, mais corrente e informal foi a nossa escolha para reproduzir o tom do original. Como o poema é polifônico, tomamos a liberdade de empregar "tu" em um trecho mais solene do prólogo, quando o "tema" ganha voz e dirige-se ao eu-lírico. No entanto, evitamos a hipercorreção para não obter o efeito oposto, e mantivemos a incongruência no emprego do pronome oblíquo, tal qual se costuma fazer no português brasileiro falado. Traduzimos, por exemplo, "eu vou te perseguir" e não "eu vou perseguilo", pouco usual na fala cotidiana do brasileiro.

O cotejo com a professora russa Ekaterina Volkova Américo foi fundamental para esclarecer pontos ainda confusos, pois a linguagem fragmentada à moda de um quadro cubista, não explicita completamente a narrativa: são os fragmentos sobrepostos que compõem o sentido. Ela ajudou-nos também a recuperar os aspectos linguísticos e culturais que haviam passado despercebidos.

Revolucionária no conteúdo e na forma, a poesia de Maiakóvski é fundamentalmente voltada para a declamação. Khardjev e Trenin afirmam que "a principal diferença entre a poesia de Maiakóvski e a de todos os poetas russos anteriores consiste no fato de que os versos de Maiakóvski são destinados à voz, à recitação em voz alta diante de um vasto auditório". 55 Consequentemente foi nosso objetivo cardeal

\footnotetext{
${ }^{55}$ Khardjev, N., Trenine, V., op. cit., p. 231.
} 
transpor a sua eloquência do russo para o português mantendo a linguagem o mais natural e próxima da oralidade quanto possível.

Pretendemos trazer a voz de Maiakóvski para o português, certamente com as marcas culturais e históricas que impregnam o poema, mas aproximando o poema do leitor brasileiro para que este capte a mesma sensação que um russo experimenta ao ler o original.

Passemos, então, a palavra ao poeta. 


\section{2. Tradução poética de Sobre Isto (do russo para o português brasileiro) ${ }^{56}$}

\section{SOBRE ISTO ${ }^{1}$}

SOBRE O QUÊ? - SOBRE ISTO? ${ }^{2}$

Neste tema,

pessoal

e banal,

cantado $^{3}$ não uma vez

mas cinco,

como um poeta esquilo ${ }^{4}$ girei em espiral

e vou girar com mais afinco.

Este tema

é agora

$$
\text { para Buda }{ }^{5} \text { uma oração }
$$

e a faca ${ }^{6}$ que o negro afia para o seu senhor.

Se Marte $^{7}$ vigora,

e nele houver um coração ${ }^{8}$,

então ele também

$$
\text { agora }
$$

$$
\text { por isto }
$$

exprime sua dor.

Este tema chega ${ }^{9}$,

às cotoveladas instiga

o mutilado pro papel,

\footnotetext{
56 A numeração de versos visa facilitar a localização dos comentários e exemplos e não coincide necessariamente com a versão original em russo apresentada nos anexos. Tampouco o total de versos numerados contabiliza examente o número de versos do poema. A transliteração dos nomes próprios, toponímia e termos apontados nas notas seguiu a tabela utilizada pela Universidade de São Paulo que consta nos anexos deste estudo (ver p. 220). A transliteração de alguns termos pretende elucidar a sonoridade dos exemplos àqueles que não dominam o idioma russo.
} 
ordena:

$$
\text { - Fira }{ }^{10} \text { !- }
$$

E o mutilado

30

do papel

desprende-se num grito de rapina,

só com as linhas a canção rebate o sol. ${ }^{11}$

Este tema chega,

ressoa da cozinha,

gira,

some como o chapeuzinho de um cogumelo,

e gigante

fica de pé por um instante

$$
\text { e desaba, }
$$

40 soterrado sob bilhetinhos ${ }^{12}$ velhos.

Este tema chega,

ordena:

- Verdade pura ${ }^{13}$ !

Este tema chega,

celebra:

$$
\text { - Formosura! - }
$$

E ainda que

$$
\text { as mãos se viguespalmem }{ }^{14} \text { - }
$$

apenas uma valsa cantarola da cruz.

50 Este tema desgasta veloz o alfabeto -

e parecia um livro fácil ${ }^{15}$ ! -

e transforma-se o

$-\mathrm{A}-$

$$
\text { em Kazbek }{ }^{16} \text { inacessível. }
$$

Confunde,

desvia do sono e da fome.

Este tema chega,

nunca se consome,

apenas diz:

- De agora em diante olha ${ }^{17}$ para mim! - 
E o olha,

$$
\text { e vai estandarte }
$$

bandeirando a terra com o fogo sedescarlate ${ }^{18}$.

É um tema ardiloso!

Mergulha sob os fatos,

nos recônditos dos instintos preparando-se para o salto,

e furioso

- atreveram-se a esquecê-lo! -

tremula;

cairão as almas das peles.

Este tema chegou colérico,

Ordenou:

- Dá-me

o freio dos dias! -

Olhou, crispando-se, o meu quotidiano

e como tempestade derramou seres e afazeres.

Este tema chegou,

os demais afastou

e só,

80 sem reserva, íntimo se tornou ${ }^{19}$.

Este tema colocou a faca na garganta.

Martelutador! $!^{20}$

Do coração às têmporas.

Este tema entenebrou o dia; nas trevas

crava - ordenou - as frontes com os versos da dor ${ }^{21}$

O nome

deste

tema: 
BALADA DA PRISÃO DE READING ${ }^{22}$

Estava de pé-posso me lembrar. Havia um brilho.

$E$ isto

então

chamava-se Neváa

Maiakóvski, O Homem ${ }^{24}$

Sobra a balada e sobre as baladas $^{25}$

Velha lábia da balada ${ }^{26}$,

mas se as palavras lanham

90 e as palavras falam sobre isto, que lanham,

rejuvenesce a lábia da balada.

Passagem Lubiánski ${ }^{27}$.

Vodopiáni $^{28}$.

Esta é

a vista.

Este é

o fundo.

Na cama ela ${ }^{57}$.

Ela está deitada.

100 Ele.

Sobre a mesa o telefone.

"Ele" e "ela": a minha balada.

Nada de muito novo.

O terrível é

que "ele" sou eu,

E que "ela"

é a minha $\operatorname{amada}^{29}$.

Por que prisão?

${ }^{57}$ Fotomontagem 1 (Anexos, p. 226). 


$$
\text { Natal }^{30} \text {. }
$$

$$
\text { Confusão. }
$$

Sem grades nas janelas da casinha!

Isso não é da sua conta.

$$
\text { Digo e repito: prisão }{ }^{31} \text {. }
$$

Uma mesa.

Sobre a mesa um fio ${ }^{32}$.

Toco e estremeço - corpo febril

Escapa das mãos o fone.

Da marca fabril -

duas flechas brilhantes ${ }^{33}$

120 cobrirraiaram ${ }^{34}$ o telefone.

O quarto ao lado.

$$
\text { De lá }
$$

soa sonolento:

- Quando isso?

De onde vem o porquinho vivo? -

A campainha já geme ${ }^{35}$ pelas chamas.

Incandescente ferve o aparato.

Ela está doente ${ }^{36}$ !

$$
\text { De cama! }
$$

130 Corra!

\section{Rápido!}

$$
\text { Já! }
$$

Com a carne em chamas, pressiono as chagas.

Num átimo o relâmpago atravessa o corpo.

Espremo um milhão de volts de tensão.

Meto meus lábios no inferno telefônico.

Furando 
buracos

na casa,

140 sobrevoa

a Miasnítskaia ${ }^{37}$

como campo lavrado,

rasgando

o cabo,

o número

feito bala

voou

até a sua patroa.

Olhava atônito o olho da patroa -

150 antes da festa trabalha por dois.

A luz vermelha acendeu de novo.

Ela ligou!

O fogo apagou.

E de repente,

como se as lâmpadas estivessem loucas,

toda a rede telefônica explode nos fios.

$-67-10^{38}$ !

Ligue para o 67-10!

Para o beco!

Rápido!

Ao silêncio da Vodopiáni!

Arre!

O que acontecerá com a eletricidade! na véspera do Natal

varre pra lixeira

a central

telefônica

inteira.

Era uma vez, na Miasnítskaia, um ancião.

170 Cem anos depois disto ainda vivia -

e só sobre isto 


$$
\text { cem anos! - }
$$

o avô às crianças repetia.

- Era sábado...

véspera de domingo...

Eu queria

carne baratinha ${ }^{39} \ldots$

Então toma!

Terremoto...

180 As solas queimam...

Tremem os pés!.. -

As crianças não acreditaram

que havia sido

tal e qual.

Um terremoto?

Invernal?

No correio central ${ }^{40}$ ?!

O telefone lança-se sobre todos

Enfiando-se por milagre pelo fino

fiozinho,

190 aberto o aro da boca do tubo,

um pogrom ${ }^{41}$ de toques destroçando o silêncio,

o telefone lança uma lava chiante.

Isto é um grunhido,

$$
\text { isto é metálico }{ }^{42} \text {, }
$$

disparou sobre as paredes,

$$
\text { esforçando-se para explodi-las. }
$$

Filhotinhos da campainha,

ricocheteando

aos milhares

das paredes 
sob as cadeiras e as camas

cambaleavam.

Do teto ao chão um enorme sino badalou.

E de novo,

feito uma esfera estridente,

decolou ao teto, chocando contra o pavimento,

e se separou em mil fragmentos de som.

Vidro sobre vidro

aço sobre aço $^{43}$

210 começaram a ressoar

ao som do telefone.

A tremelicar

com a mãozinha

a casa-chocalho,

o telefone afundava na inundação de toques.

A madrinha ${ }^{44}$

Pelo sono

pouco se vê -

um ponto de pupila

alfineta as bochehas tórridas.

220 Lenta, a cozinheira ${ }^{45}$ levantou,

vai,

escarrando.

É como uma maçã enrugada.

Os pensamentos encrespam sua fronte.

- Quem?

Vladímir Vladímitch ${ }^{46} ? !$

Ah tá! -

Foi, arrastando o chinelo.

Chega. 
Os passos afastam-se...

Mal se ouvem...

O resto do globo vai para longe

não se sabe aonde,

só o desconhecido aponta o gancho para mim.

Congelados, os conferencistas de todas as assembleias, não conseguem concluir o gesto.

Assim, como estavam,

boquiabertos,

assistem ao Natal dos Natais.

Veem a vida

de barraco em barraco.

A casa deles -

a eterna lama habitual.

Como a se espelhar,

esperavam,

a me mirar,

um mortal duelo de amor.

250 Petrificaram-se os estrondos das sirenes.

O rebuliço não gira as rodas nem os passos.

Apenas o campo do duelo

e o tempo-doutor

com as infindas bandagens de morte curadora.

Moscou -

além-Moscou os campos se calaram.

Mares -

além-mares, cordilheiras complanadas. 
O universo

todo

como num binóculo abrigado,

um binóculo enorme (só que do lado contrário).

O horizonte aprumou-se

$$
\text { plano-plano }
$$

Um nastro.

Teso como um barbante esticado.

Uma ponta

sou eu no meu quarto,

você, no seu quarto, o outro lado.

270 E no meio,

assim

como nunca sonhado,

um tanto orgulhosa de sua roupa branca nova,

pelo universo

estendeu-se a Miasnítskaia,

miniatura de marfim.

Clareza.

Tortura da transparente clareza.

Na Miasnítskaia,

detalhe do traçado hábil,

o cabo

fininho -

mas é apenas um filete!

E tudo

está por um fio.

O duelo

$\mathrm{Um}$ !

Apontam o fone. 
Abandone

a esperança.

290

Dois!

$$
\mathrm{Ela}^{47} \text { parou }
$$

totalmente,

sem tremer,

diante

de meus

olhos encobertos e suplicantes.

Quero gritar à mulher molenga:

- Por que está se achando?

$$
\text { Aí em pé como D’Anthès! }{ }^{48}
$$

$300 \quad$ Ligeiro,

ligeiro escava o cabo

como projétil

de qualquer peso e peçonha. -

Mais terrível que a bala -

vem de lá

para cá,

disparada pela cozinheira a bocejar,

qual coelho tragado na barriga de uma jiboia

pelo cabo,

310 vejo,

a palavra rastejar.

Mais terrível que as palavras -

dos tempos remotos remotíssimos,

quando ainda, caninos pra fora

capturava a fêmea o homem caçador,

$\operatorname{arrasta-se}^{58}$

do fio -

o ciúme escorchador,

monstro dos tempos trogloditas de outrora.

${ }^{58}$ Fotomontagem 2 (Anexos, p. 227). 
320 Mas será que...

Pode ser!

Ninguém no telefone penetrou ou penetra,

não há nenhum focinho trogloditesco ${ }^{49}$.

Sou eu no telefone.

Eu me espelho no metal.

Agarre-o e escreva circulares do Comitê Central ${ }^{50}$ !

Vai - confronte com Erfurt ${ }^{51}$

a verdade dessa esfera!

Pela primeira dor

330

disparatado,

extremado,

superado o cérebro,

abre caminho a fera.

O que pode acontecer com um homem

Bela aparência.

Camaradas!

Imaginem só!

Em Paris, na turnê estival,

o poeta,

estimado colaborador do jornal $^{52}$,

340 garatuja a cadeira com as garras dos sapatos.

Ontem era um homem -

e de uma vez,

com caninos, minha aparência ursifiquei ${ }^{53}$ !

Peludo.

A camisa pende como pelo.

Vai fazer o mesmo?!

Bater nos telefones em atropelo!?

Retorne aos seus! 
Aos mares de gelo!

Ursificação ${ }^{54}$

350 Como um urso

mortalmente enfurecido,

puxo o peito

contra o telefone

meu inimigo.

E o coração

penetra profundo no arpão.

Sangra.

Um riacho de cobre rubro.

Rugidos e sangue.

360

Lambe, escuridão!

Não sei

se choram

os ursos,

mas se choram,

é assim mesmo.

Assim mesmo:

sem falsa compaixão

choramingam,

inundando o desfiladeiro inteiro.

370 Assim faz seu ursesco Balchin ${ }^{55}$,

desperto por uivos, rosna atrás de mim.

É justamente o que os ursos fazem:

imóveis,

focinho ao ar,

ursamente ${ }^{56}$,

uivam,

se acabam em uivos 
e na toca vão se deitar,

arranhando o covil com unhas e dentes.

380 Cai uma folha.

Avalanche.

Inquietação.

Que as espingardas - pinhas

não despenquem de uma vez.

Só assim é possível a sonhurselevação ${ }^{57}$ :

pelas lágrimas e pelos que turvam a lucidez.

Cama.

Barras de ferro.

Velho cobertor.

390 Jaz sobre as barras de ferro.

\section{Calmaria.}

\section{Estupor.}

Um arrepio veio.

Perpassou as barras de ferro.

O lençol do leito balança e balbucia.

A água ${ }^{58}$ lambeu os pés fria.

De onde vem a água?

Por que tanta?

Fui eu que chorei.

Um chorão.

Chuva.

Não é possível -

não se pode chorar tanto.

Maldita banheira!

Atrás do sofá uma aguaceira.

Sob a mesa, 
atrás do armário, água.

Do sofá,

de água ensopada,

410 rumo à janela navegou a mala.

Chaminé...

Bituca...

Eu mesmo joguei.

Tenho que contê-la.

Teima em tostar.

Terror.

Aonde?

Pra qual chaminé?

Um quilômetro ${ }^{59}$.

420 Ao cabo de um quilômetro a margem em chamas.

Tudo encharcado,

até mesmo o cheiro de repolho

da cozinha,

eterna e

docemente açucarado.

Um rio.

Ao longe as margens.

Que vazio!

Como uiva o vento vindo do Ládoga ${ }^{60}$ no teu vestígio!

$430 \quad$ Um rio.

Magnífico rio.

Um frigorífico.

Encrespa o rio.

Eu no meio.

Como um urso polar,

começo a escalar o bloco de gelo,

navego do alto da minha almofada-gelo.

Renova o litoral

de local em local.

440 Sob mim a almofada glacial. 
Do Ládoga sopra o vento.

A água corre.

Voa a balsalmofada ${ }^{61}$.

Navego.

Febrilizo $^{62}$ na gelalmofada.

O único sentimento que a água não lavou:

eu devo navegar

sob os arcos da cama

ou

$450 \quad$ sob alguma ponte.

Foi bem assim:

o vento e eu.

Este rio!...

Não este.

Um outro.

Não, não um outro!

Foi assim.

Estava parado.

Sim - brilhava.

Agora começo a lembrar.

O pensamento cresce.

Não consigo controlar.

Para trás!

A água não deixa a balsa circular.

É cada vez mais evidente...

cada vez mais claro...

não dá para evitar...

Ele chegará!

Lá!!! 
470

Ondas lavam metálicos pilares.

Imóvel,

terrível,

cravado nos quadris

da capital,

que criei em instantes febris,

em pé

sobre seus pilares centandares ${ }^{64}$.

Bordou o céu de pilastras aéreas.

480 Das águas insurge-se o espetáculo de aço.

Ergo os olhos para o alto,

mais alto...

Bem ali!

aparado no parapeito da ponte...

Perdão, Nevá!

Não perdoa,

prefere me expulsar.

Tenha piedade!

A corrida enraivecida não se compadeceu.

$490 \quad$ Ele!

Ele -

sobre um fundo inflamado, no céu,

está o homem por mim atado.

Em pé.

O cabelo desgrenhado e arrepiado.

Pateio $^{65}$ as orelhas ${ }^{59}$.

Tão inúteis!

$\mathrm{Eu}$ ouço

a minha,

${ }^{59}$ Fotomontagem 3 (Anexos, p. 228). 
A lâmina da voz trespassa as minhas patas.

Minha própria voz -

implora,

$$
\text { pede }^{66} \text { : }
$$

- Vladímir!

Pare!

Não me deixe!

Então por que não permitiu

me atirar?

510 Despedaçar o coração com força no pilar?

Há sete anos aqui me conservo.

Observo essas águas,

Ao parapeito preso pelas linhas dos versos.

Há sete anos essas águas não tiram os olhos de mim.

Quando, então,

quando a libertação chegará enfim?

Quem sabe entrou na dança?

Beija?

Come?

Cultiva a pança?

Você,

no cotidiano mesquinho,

$$
\text { naquela felicidade familiar }{ }^{67} \text {, }
$$

quer se insinuar como um franguinho?!

Nem pensar!

Sua mão despenca.

Ameaça

seca

no fosso sob a ponte.

$530 \quad$ - Nem pense em fugir!

Fui eu

que te chamei.

Eu vou te encontrar ${ }^{68}$. 
Cercar.

Arruinar.

Torturar!

Lá,

na cidade, a festa.

Ouço o seu trovão.

E daí?!

Peça para virem.

Traga a deliberação do comitêt ${ }^{69}$.

Confisque a minha pena, revogue-a.

Enquanto

do rio

Nevá,

lá do fundo,

550

o amor-salvador

não chegar até mim,

você também vagará,

e o amor não terá nesse mundo.

Reme!

Afunde entre as pedras das casas enfim.

Socorro!

Pare, almofada!

Esforço inútil.

Remo com minha pata -

péssima pá.

560 A ponte encolhe.

A correnteza do Nevá

me leva para lá, 
lá, lá.

Estou longe já.

Um dia de viagem talvez.

Há um dia

vi a minha sombra na ponte.

Mas o ruído de sua voz está no meu encalço.

$\mathrm{Na}$ perseguição estirou as velas da ameaça.

570 - Está tramando esquecer o brilho do Nevá?!

Substituí-la ${ }^{70} ?$ !

Não dá!

Lembre-se do marulho até a morte te levar,

marulhando o "Homem". -

Começou a gritar.

Será que superam isso?!

O baixo da borrasca ${ }^{71}$

não será superado por ninguém.

Socorro! Socorro! Socorro! Socorro!

580

Lá

na ponte

sobre o Nevá,

há um homem! 
Renova o litoral -

de local em local.

Sob mim -

a almofada - glacial.

O vento do Ládoga encrespa a crista.

Alça voo

o bloco-balsa.

Socorro! - a saraivada de palavras ressalta o sinal.

Caio, aniquilado pelo solavanco.

O riacho acabou -

é mar aberto.

O oceano -

enorme e incerto.

Socorro!

Socorro!...

Cem vezes seguidas

600 urro qual bateria de canhões.

Embaixo

sob mim

cresce o quadrado,

a ilha-almofada cresce.

Esvai-se, esvai-se,

esvai-se o som surdo.

Surdo, e mais surdo, e mais surdo...

Nada de mar.

$\mathrm{Eu}-$

sobre a neve. 
Ao redor -

quilômetros de terra firme.

Firme - é modo de dizer.

É neve a derreter.

Abandonado ao bando da nevasca.

Que terra será esta?

Que região?

Groen-

is-

620

amor-lândia ${ }^{74}$ ?

A dor dos fatos

Entre as nuvens amadureceu o melão lunar, obscurecendo pouco a pouco a parede.

Parque Petróvski ${ }^{75}$.

Corro

Khodynka $^{76}$

em minha jugular.

Adiante Tverskáia ${ }^{77}$ em rede.

Eiiiiiiiiiii $^{78}$ !

Até à Sadóvaia 79 atiro um "ei”!

630 Não sei se varal

ou veículo,

mas acabei

com o focinho

enfiado embaixo da neve.

Projétil de imprecações.

"A NEP ${ }^{80}$ te cegou?!"

Você tem olhos pra quê?!

Ei, você!

Filho de uma nep! 
640 Palhaço!"

Ah! Pois é,

neste percurso,

sou um urso.

Foi um engano!

Saiba -

passante,

que não sou urso,

sou apenas semelhante.

O salvador

Lá

650

da barreira

vem um rapazola.

Passo a passo vem crescendo.

A lua

circunda sua cabeça com uma corola. ${ }^{81}$

Eu o convenço

a subir na barca

imediatamente.

É o salvador!

Um tipo de Jesus.

660 Sereno e bondoso,

coroado de $l u z^{82}$.

Mais perto.

Rosto jovem e sem pelos.

Nada de Jesus!

Mais gentil.

Mais juvenil.

Chegou mais perto,

porte de Komsomol ${ }^{83}$. 
Sem gorro nem peles.

$670 \quad$ Ataduras $^{84}$ e túnica militar.

Ora entrelaça as mãos,

como se orasse.

Ora as agita,

como num comício a discursar.

A neve é algodão.

O rapazinho caminhava pelo algodão.

Algodão no ouro -

há algo mais vulgar?!

Mas tamanha é a tristeza,

680

que só resta parar

e a ferida ferir!

Numa romança ultracigana ${ }^{85}$ se fundir.

Romança $^{86}$

O rapazinho andava fitando o pôr do sol.

Pôr do sol de extraordinário amarelo.

Até a neve amarelava na entrada da Tverskáia.

O rapazinho andava, não via nada.

Seguia,

subitamente

cessou.

$690 \quad$ Na seda

das mãos

o aço.

Há uma hora o ocaso o fita, vista fixa,

atrás do rapaz uma leve faixa.

A neve, crepitando, triturava as juntas.

Por quê?

Para quem? 
Como isso se encaixa?

O rapaz era revistado pela vilania-ventania.

$700 \quad$ Um bilhete seu voou ao vento.

O vento para o parque Petróvski começou a ressoar:

- Adeus...

Paro por aqui...

Peço para não me culpar ${ }^{87} \ldots$

710 Como é possível

sermos tão parecidos?

Que horror!

$$
\text { É incrível! }
$$

$$
\text { Já pra poça }{ }^{88} \text { ! }
$$

A jaqueta ensanguentada despir.

Bem, camarada!

A situação daquele é pior sete anos na ponte, sem poder sair.

A jaqueta mal cabe -

$$
\text { calibre }^{89} \text { errado. }
$$

Não consegue se ensaboar -

os dentes não param de bater.

Patas e focinho pelados,

O gelo como espelho...

A luz como lâmina...

Somos quase,

quase iguais.

Corro.

Os miolos processam endereços.

730 Primeiro,

Pra Presnia ${ }^{90}$,

Pra lá, 
Pelos quintais.

Pro covil familiar, por instinto,

me arrasto aos tropeços.

Atrás de mim,

em longa fila,

os filhos ,

e filhas

de toda a Rússia.

Pais $_{\text {universais }}{ }^{11}$

- Volódia!

Aqui, no natal!

Que felicidade!

Alegria geral!... -

750 Antessala trevas

Cômodo eletricidade.

De repente -

$\mathrm{Na}$ diagonal, os rostos dos meus.

- Volódia!

Meu deus!

O que houve?

O que é isso?

Está todo vermelho.

Mostre a gola!

760 - Deixe pra lá, mãe,

lavo em casa.

Tenho a vastidão -

do oceano agora.

Isso não importa.

Meus queridos $!^{92}$

Amados! 
Vocês me amam mesmo?

Amam?

Sim?

770 Então me ouçam!

Tia!

Irmães!

Mãe!

Apaguem a árvore de natal!

Tranquem a casa!

Eu levarei vocês...

Vamos andando...

Avancem...

Agora mesmo...

Todos!

Vamos pegar tudo e partir.

Não tenham medo -

Não é nada longe -

Uns 600 quilometrinhos ${ }^{93}$.

Chegaremos lá rapidinho.

Ele espera.

Subiremos direto na ponte.

- Volódia,

minha alma ${ }^{94}$,

calma! -

Mas eu respondo

imerso no chiado doméstico:

- Então é assim?!

Trocam o amor pelo chá? ${ }^{95}$

$\mathrm{O}$ amor pelo remendo das meias ${ }^{96}$ ? 
Não é você -

não é a mamãe Alessandra Alekseevna ${ }^{97}$.

O universo todo semeado de família.

Olhem,

cerdas de mastros de navios -

a cunha de Oder ${ }^{98}$ crava na Alemanha.

810 Desce, mamãe,

já estamos em Estetino ${ }^{99}$.

Agora,

mamãe,

aceleremos para Berlim.

Agora voarão com o ronco do motor:

Paris,

América,

a ponte do Brooklyn,

o Saara,

820

e aqui,

com uma negrinha de cabelos crespos,

um negrinho beberica o chá em família.

Amassará como um colchão de penas

a vontade

e a pedra.

A Comuna -

vai se tornar una.

por séculos

viveram cada um no seu domínio

830 e hoje vivem em condomínio!

Outubro trovejou,

castigador,

julgador.

Vocês, 
sob a sua asa de fogo,

se despediram

arrumando a porcelana.

As teias de aranha não se penteiam com uma estaca.

Desapareça, casa,

840

lar natal!

Adeus! -

Abandono a série de degraus.

- Para que serve a família?!

Amor de pintinho!

Amoreco de galinha choca!

As miragens da Presnia ${ }^{100}$

850

Corro e vejo -

está na cara,

como as torres da Kudrinskaia ${ }^{101}$

eu mesmo

venho

ao meu encontro

com presentes debaixo do braço.

Mastros em cruz na tempestade estirados.

A nave derrama seu rastro.

860 Maldita seja,

vazia leveza!

A lonjura ${ }^{102}$ escancarou os dentes das casas.

Sem pessoas nem barreiras.

As neves queimam,

deserto.

E detrás da janela,

no fogo, só as agulhas do abeto.

Contra as pernas, 
como freios, ligeiros,

870 ergueram-se paredes, janelas enfileiradas.

Pelos vidros,

sombras,

silhuetas do tiro ao alvo

reviravam-se nas janelas,

convidando a entrar.

Olhos colados no Nevá,

congelado,

parado, ele espera -

vão ajudar.

880 Na primeira soleira que surge

avanço a perna.

Na entrada um bêbado ventilava delírios.

Ensobriou e se mandou ${ }^{103}$.

Por um momento,

inunda a sala

o lamento de um discurso:

- Urso,

urso,

urso,

890

urs-O-O-O-O...-

O marido de Fekla Davidovna comigo e com todos os conhecidos

Então,

curvando como ponto de interrogação,

o anfitrião deu uma olhada:

- Vejam só!

900 Maiakóvski!

Que beleza de urso! -

Prosseguiu o anfitrião desfazendo-se em gentilezas: 
- Por favor!

Passa.

Não se incomode -

Cada um entra como pode.

Uma alegria inesperada, como disse Blok. ${ }^{104}$

Minha mulher - Fekla Dvidna.

Minha filha,

igualzinha a mim,

dá para ver -

dezessete anos e meio.

E esse é...

Parece que vocês já se conhecem! -

Mortos de medo junto aos ratos no covil,

De debaixo da cama saíam os amigos.

Os bigodões -

espanador para pó de lâmpada -

emergem de sob as mesas os companheiros de barril.

920 Arrastam-se de sob o armário leitores, recitadores.

Mas como descrever um desfile de sem rostos? ${ }^{105}$

Vão e vão, em pacífica procissão.

Em suas barbas brilham as teias de aranha dos apartamentos.

Tudo examente igual ${ }^{60}$,

secular.

Sem o chicote-

a égua da vida não se move.

Somente no lugar de espíritos e fadas,

o anjo da guarda -

um inquilino em calças de militar ${ }^{106}$.

Mas o mais terrível:

a estatura,

a pele

as roupas,

${ }^{60}$ Fotomontagem 4 (Anexos, p. 229). 
o meu próprio caminhar! -

em um deles

me reconheci -

$$
\text { parecidos como gêmeos }{ }^{107} \text {. }
$$

Nos colchões,

940

erguendo os tecidos roídos,

percevejos ${ }^{108}$ cumprimentam de patas erguidas.

O samovar irradia reluzindo raios -

quer abraçar com seus braços samovarianos.

Marcadas de moscas,

as coroinhas

do papel de parede

coroam sozinhas os parentes.

Agita-se a fanfarra dos anjos-clarins,

avermelhados sob o brilho dos ícones.

950 Jesus,

levantando

a coroa de espinhos,

cumprimenta amavelmente.

Até Marx,

atrelado à rubra moldura,

arrastava os grilhões da usura.

Cantarolam os pássaros em cada poleiro,

os gerânios enfiam nas narinas o seu cheiro.

Assim como estão,

sentadas nos retratos,

de cócoras,

cordialmente as avós saem das fotos.

Todas cumprimentam,

abrem um sorriso falso em comunhão;

uma com voz de baixo,

a outro com o soprano

de um sacristão.

- Boas festas! 
Boas festas!

970

Boas festas!

Boas festas!

Bo-

as -

as! -

$\mathrm{O}$ anfitrião

ora mexe uma cadeira,

ora bufa

varrendo as migalhas da toalha.

980 - Mas eu não sabia!..

Se eu soubesse eu teria ido ontem...

Mas pensei que estivesse ocupado...

Em casa...

Com os parentes...

Pedidos sem sentido

$990 \quad$ Meus parentes?!

S-i-i-i-m -

são uns tipos diferentes.

Só uma bruxa com a vassoura acharia igual! ${ }^{109}$

Meus parentes

$$
\begin{aligned}
& \text { de Ienissei }{ }^{110} \\
& \text { e de } \mathrm{Ob}^{111}
\end{aligned}
$$

estão chegando,

deixam pegadas de animal.

Qual é a minha casa?!

1000 Acabo de sair de lá.

No travesseiro - gelo

naveguei pelo Nevá - 
minha casa

no meio das barragens

congelou $^{112}$,

e lá...

Escolhia as palavras

ora as mais insinuantes,

ora rugidos terríveis,

$$
\text { ora esbadalando }{ }^{113} \text { liramente }^{114} \text {. }
$$

Rumo à eterna glória

desviei das vantagens,

supliquei,

ameacei,

implorei,

propagandeei.

Mas era para todos...

para vocês próprios...

para vocês mesmos...

1020 Bem, por exemplo, o "Mistério"115 -

não foi para mim afinal, foi?!

Pois o poeta e etc...

É para todos nós crucial...

Não só para mim mesmo -

$$
\text { não é um capricho pessoal... }
$$

Sou, digamos, um urso, falando curto e grosso...

Mas são possíveis os versos...

Esfolam a pele até o osso?!

Faça um forro de rimas -

$$
\text { e terá um casaco!.. }
$$

Depois ao pé da chaminé...

$$
\text { o café... }
$$

fumam charutos...

Uma coisinha de nada:

uns dez minutos...

Mas tem que ser agora, 
antes que seja tarde...

Talvez aplaudam...

Mas dizer algo -

1040 espera sentado!..

Mas que seja imediato...

$$
\text { e pra valer...- }
$$

Ouviram, sorrindo, o famoso bufão.

Rolavam pela mesa o miolo de pão.

As palavras na cabeça,

$$
\begin{aligned}
& \text { e no prato - } \\
& \text { como ervilhas. }
\end{aligned}
$$

Um se comoveu,

$$
\text { amolecido pelo vinho: }
$$

1050 - Espeeeera...

espeeeera...

É tão simples.

Eu vou!..

Dizem que ele espera...

$$
\text { ali na ponte... }
$$

Eu conheço...

É na esquina da rua Ponte Kuznetski. ${ }^{116}$

Me deixem ir!

$$
\text { Vamos lá! - }
$$

1060 Nos cantos -

um chiado:

$$
\text { - Ench-ch-ch-eu a caaaara! }
$$

Pare de reclamar!

Comer e beber,

beber e comer -

e jogar $66^{117}$ até morrer!

$$
\begin{aligned}
& \text { A NEP - } \\
& \text { é prática. }
\end{aligned}
$$

Encha o copo,

corte mais um pedaço. 
Futurista,

$$
\text { Pega aí! - }
$$

O bloco de maxilares não se envergonha de nada,

soa dos maxilares sobre os maxilares a trovoada.

Emergiram

de profundezas patéticas,

entre os cálices,

palavras de disputas poéticas.

No colchão,

fazendo uma saudação,

$$
\text { entraram os percevejos. }
$$

O pó secular se acumulou nos objetos.

E ele está lá -

$$
\text { pregado no parapeito. }
$$

Ele espera,

carrega a certeza no peito:

$$
\log 0 \text { ! }
$$

Mais uma vez de cabeça,

$$
\text { mais uma vez contra o cotidiano }
$$

1090 bato com a bomba das letras.

Novamente,

ataco a torto e a direito.

Mas é estranho:

as palavras penetram sem efeito.

1100 Os mosquitos silenciam o baixo com seu trinado.

Envoltos no ar, silenciaram-se os pratos.

O papel nas paredes, desbota... 
desbota...

Afunda nos tons de cinza das águas-fortes.

Da parede,

sobre a cidade saturada

\section{Böcklin ${ }^{118}$,}

como Moscou transformada na "Ilha dos mortos"

Há muito, muito tempo atrás

$$
\text { E ainda mais - }
$$

Agora.

Uma coisa parca!

Lá,

na barca,

cerrado em um sudário,

o barqueiro imóvel.

Não sei se mares,

$$
\text { ou vales }{ }^{120}
$$

seu sussurro esvai-se no silêncio.

E além dos mares -

$$
\text { os álamos }{ }^{121}
$$

elevam ao céu a morbidez ${ }^{122}$.

Pois bem -

dou um passo!

$$
\text { E súbito }
$$

os álamos

1130 se separaram do dossel,

$$
\begin{aligned}
& \text { e foram, } \\
& \text { pisoteando os ramos. }
\end{aligned}
$$

Os álamos tornaram-se a medida do silêncio sepulcral, guardas noturnos,

floresta policial.

Quadruplicando-se no horizonte,

$$
\text { o branco Caronte }{ }^{123}
$$

tornou-se uma coluna do correio central. 
Como a cunha corta o sono,

e fende as cabeçadormecidas ${ }^{124}$

súbito

tudo some,

e vê apenas achas retorcidas.

Como os tambores das ruas,

entram

no sonho,

1150 e súbito começa a lembrar,

que a melancolia mora lá

naquela esquina,

e atrás dela

está ela -

a culpada.

A esquina encobre as janelas ${ }^{125}$ com a mão espalmada,

vidro após vidro arranco o cerco.

A vida inteira

nesse jogo das janelas ${ }^{126}$.

1160 Ponto para elas -

e eu perco .

Um negro $^{127}$

cilada das miragens -

sobre as janelas

traça atrevido marcas alegres.

O baralho de vidros,

$$
\text { num triunfo clariflamejante } \mathrm{e}^{128} \text {, }
$$

resplandesce atrevido entre os noturnos dedos.

Se fosse como antes -

$$
\text { e crescesse, }
$$

e voasse com os versos pela janela.

Mas não, 
apoie na umidade da parede.

Os versos

e os dias já não têm a mesma sorte.

Congelam as pedras.

Arrepio de morte.

E raramente passam as vassouras.

Como cuspes,

os sapatos na mão,

galgo os degraus.

A dor no coração não quer calar,

começa a selar elo a elo.

Foi assim

que ele,

$$
\text { o assassino Raskólnikov }{ }^{129}
$$

veio a campainha tocar.

Os bando de convidados vai pelas escadas...

Eu cedo,

deixo os degraus -

$$
\text { me emparedo. }
$$

Esforço para me intromofar ${ }^{130}$ na parede

e ouço -

as cordas soarem.

Talvez esteja sentada,

assim,

como quem não quer nada.

Só para os convidados,

para as grandes massas e seu clamor.

1200 Mas seus dedos,

$$
\text { no auge do desespero, }
$$

executam indolentes, achincalhando a dor. 
1210 E os corvos, estão convidados?!

A folha da porta

entorta e fustiga os flancos do corredor.

Gargantas esguichadas,

goelas esganiçadas

vem se arrastando a embriaguez-torpor.

A fissura

de uma abertura.

Vozes

velozes em surdina:

1220 “- Aninha ${ }^{131}$

tão vermelhinha!"

As tortas...

O forno...

O casaco...

Ajuda...

Em torno dos ombrinhos...

Palavras surdas no one-stepante ${ }^{132}$ compasso,

e outra vez as palavras através do compasso one-stepante:

"Por que estão tão animados?

1230 É mesmo?!"

Misturados...

Novamente a abertura iluminou a frase.

Não dá pra entender as palavras -

sobretudo na primeira fase.

Palavras dessa qualidade

(não por maldade):

“Aquele lá quebrou a perna,

mas vamos nos divertir, se deus permitir,

deixe isso pra lá, vamos dançar!”.

1240 Sim, 
são as suas vozes.

Gritos conhecidos.

Reconheci e congelei,

aniquilado,

recorto frases nos tipos dos gritos.

$\operatorname{Sim}-$

são eles -

e falam de mim.

Farfalhar.

1250 Folheiam, parece, partituras.

"Você disse a perna?

Que engraçado!”

E novamente

os brindes entrechocam os copos,

faíscas de vidro espalham-se nos corpos.

E novamente

o bêbado:

"Mas que interessante!

Então quer dizer que ele se partiu em dois?"

1260 "Lamento informá-lo, por mais triste que seja,

mas não se partiu, dizem,

ele apenas trincou".

E novamente

o bater das portas e os crocitos,

e novamente as danças desgastadas sobre o piso.

E novamente ${ }^{61}$,

ardendo em brasas nas paredes, as estepes

ressoam e suspiram no two-step ${ }^{133}$.

1270

Espero que não seja você

${ }^{61}$ Fotomontagem 5 (Anexos, p. 230). 
De pé contra a parede.

Eu não sou eu.

Que a vida se esfacele na loucura atroz.

Mas não a sua, não a sua

insuportável voz !

Os dias,

$$
\text { os anos vendi à mesmice }{ }^{134} \text {, }
$$

eu mesmo sufocava com tanta sandice.

Ele

corroeu a vida com a névoa apartamental ${ }^{135}$.

Chamava:

decida

da janela

pra calçada!

Eu fugia ao apelo da janela aberta,

fugia amando.

Seja de correspondência incerta,

sejam apenas versos,

apenas passos no escuro -

escrevinha as linhas,

e as almas tornam-se minúsculas,

e ama em versos,

$$
\text { mas em prosa perco a voz }{ }^{136} \text {. }
$$

E simplesmente não consigo dizer,

$$
\text { não sou capaz. }
$$

Mas onde, minha querida,

$$
\text { onde, minha amada, }
$$

onde

- no meu canto! -

eu traí o meu amor?

Aqui

cada som,

é uma confissão, 


$$
\text { um apelo. }
$$

E somente no canto - nenhuma palavra cancelo.

Lanço-me no gorjeio,

Os olhos em cheio

$$
\text { no alvo final! }
$$

Orgulhoso de minhas duas pernas,

Não se mexa! - gritarei. -

$$
\text { Inteiro! - }
$$

Direi:

- Veja, até aqui, minha querida, destroçando o horror da rotina com as minhas canções,

1320 defendo o nome amado,

e te

poupo

das minhas próprias maldições.

Venha,

reaja aos versos com explosão

Percorri todos - estou aqui.

Você: minha única salvação.

Levante!

Vamos até a ponte! -

1330 Como um touro no matadouro

sob a pancada do aço

curvo a minha cachola ${ }^{137}$.

Eu vou me dominar,

$$
\text { irei até lá. }
$$

Um segundo -

$$
\text { e darei um passo. }
$$


Aquele segundo final,

aquele segundo

virou um início,

o início

de um bramido fenomenal.

O norte inteiro bramia louco.

Pela trepidação do ar,

pela vibração,

desconfio -

$$
\text { está sobre Liuban }{ }^{138} \text {. }
$$

Pelo frio,

ouço a porta bater,

desconfio -

está sobre Tver ${ }^{139}$.

Pelo rumor -

1360 que escancara as janelas para mim -

desconfio -

$$
\text { precipita-se para Klin }{ }^{140} \text {. }
$$

Uma tempestade em Razumóvskoe ${ }^{141}$.

$$
\text { Inundação. }
$$

Agora para Nikoláievski ${ }^{142}$,

$$
\text { a estação. }
$$

Tudo de um fôlego só,

e sob os pés

$$
\text { os degraus }
$$

1370 desaparecem,

$$
\text { começam a boiar, }
$$

soerguidos pela espuma do Nevá.

$\mathrm{O}$ terror chegou.

Tomou todo o cérebro de cara, 
Tensionando a fileira de nervos

descarregando mais e mais

estourou,

cravou:

- Para!

1380 Vim de 7 anos atrás,

de 600 quilômetros,

vim ordenar:

Não!

Vim mandar:

Deixa pra lá!

Deixa!

Não é preciso

nem palavras,

nem pedidos

1390 Qual o sentido -

você

conseguiria

sozinho?!

Espero

a terra desamorada ${ }^{143}$

reunida,

toda

a massa humana

do mundo.

1400 Aqui estou há sete anos,

e ficarei mais duzentos,

nesse eterno tormento,

pregado aqui de pé

nessa espera.

Anos na ponte,

desprezado,

ridicularizado,

como redentor do amor terreno, 
devo ficar,

1410 e ficarei por todos,

por todos expiarei,

por todos chorarei.

Rotunda ${ }^{144}$

As paredes no two-step estilhaçavam-se

em três,

1420 estilhaçavam-se em quatro tons,

em cem...

$\mathrm{Eu}$, parecendo um ancião,

em alguma Montmartre

trepo -

pela milésima vez -

no assento.

Há tempos os clientes estão fartos.

Conhecem de antemão

toda a ladainha

1430 vou chamá-los

(nada de novo no fato!)

para ir a algum lugar,

salvar alguém.

Para desculpar o abuso

o patrão explica aos clientes:

$$
\text { - É russo! - }
$$

As mulheres -

braçadas de carne e de trapos,

caçoam

1440

esforçando-se para me arrastar

pelas pernas:

"Não vamos. 
Ficou biruta!

Somos prostitutas".

Se o Sena fosse o Nevá!

Com os anos futuros a respingar

na escuridão do Sena ${ }^{145}$ começo a vagar,

expulso de todo o já.

Colossal,

ridicularizado,

acossado,

alquebrado,

nos bulevares

berro entre os capacetes militares;

- Sob a bandeira vermelha!

Marchem!

Sobre o cotidiano!

Através da cérebro do homem!

Através do coração da mulher! -

1460 Hoje

me perseguiram

com extraordinário furor.

E com que calor!

Semimorte

Preciso

1470 ventilar um pouco a cabeça.

Vou,

vou, aonde me estabeleça.

Embaixo os sargentos-sonoros assobiam,

garis varrem

$$
\text { o corpo }
$$

da calçada fria 
Beira o dia.

Levanto à sombra do Sena,

uma cinza cena de cinema.

1480 Aí esta -

eu os olhava da carteira

como um colegial -

mapas da França faíscam na lateral.

Da corrente de recordações reminiscentes

rastejo para me despedir

dos países do Oriente.

Alcei voo

e fiquei

atolado.

Atado pelos farrapos das minhas calças.

Tateei -

escorregadio

como uma cebola.

Enorme bola.

1500

Folheadourada ${ }^{146}$.

Sob o bulbo

o uivo dos sinos.

A noite bordou dentes nas paredes.

Estou sobre Ivan

o Grande ${ }^{147}$.

As torres do Kremlin como espadas.

Mal se veem assim

as janelas de Moscou.

Alegria.

Os pinheiros se transnatalizaram ${ }^{148}$ 
Uma onda jorrou para a garganta do Kremlin:

ora uma canção

ora o retinir do espírito de natal.

Das sete colinas ${ }^{149}$,

despenhou-se no Darial, ${ }^{150}$

Moscou lançou

a festa

como Terek $^{151}$.

Arrepiam-se os cabelos.

1520

Arrasto-me como perereca.

Tenho medo -

se eu der mais um passo em falso,

este

velho

terror do natal

me

redemoinhará para Miasnitskaia - cadafalso.

Os braços em cruz,

em cruz

no topo,

tento me equilibrar ${ }^{62}$,

terríveis gestos.

Noite sem luz ${ }^{153}$,

não vejo um palmo diante do nariz.

1540 Lua.

Sob mim

o Machuk ${ }^{154}$ de gelo.

${ }^{62}$ Fotomontagem 6 (Anexos, p. 231). 
Não há jeito de me equilibrar,

como no domingo de Ramos mãos de papelão ${ }^{155}$ a balançar.

Vão me ver.

Aqui sou todo visível.

Olhem -

o Cáucaso pulula Pinkertons ${ }^{156}$.

1550 Eles me viram.

Deram o aviso universal.

Aos amados,

amigos

pessoas em listras

a todo o universo guiou com o sinal.

Apressam-se para acertar as contas,

vão os duelistas.

Eriçado,

dentes arreganhados

1560 mais e mais...

Cospem nas mãos ${ }^{157}$.

Com as palmas suculentas,

de mãos cheias,

com o vento,

sem piedade,

incontáveis

bofetadas esfolaram a bochecha.

Galerias -

espigas de lojas luvosas ${ }^{158}$,

1570 as damas,

agitando uma fragrância melosa,

tiraram,

e atiraram as luvas ${ }^{159}$ na minha cara,

saltavam na cara as lojas luvosas.

Jornais,

revistas, 
não olhem feito boçais!

Para ajudar o que voa na minha fuça,

aguça

1580

os insultos de jornal em jornal.

Boato na boca do estômago ${ }^{160}$ !

Pegue, calúnia imortal!

E assim sou um mutilado na dor do amor.

Deixem para os seus os baldes de lama.

Eu não vou impedi-los.

Por que tanto rancor?

Sou só versos,

$$
\text { sou só alma }
$$

E lá embaixo:

- Não!

Você é nosso inimigo secular.

Um já foi pego assim -

$$
\text { um hussardo }{ }^{161} \text { ! }
$$

Toma pólvora,

o chumbo da pistola, vem cheirar.

Abre a camisa! ${ }^{162}$

$$
\text { Não banque o covarde! - }
$$

Mais forte que o temporal sem fim,

mais vívido que o trovão,

sobrancelha contra sobrancelha ${ }^{164}$,

em uníssono,

de todos os fusis,

de todas as baterias de canhão,

de cada mauser e browning ${ }^{165}$,

1610 a uma centena de passos, 
a dez,

a um par,

à queima-roupa -

descarga após descarga.

Param para respirar,

e de novo cospem chumbo à larga

Acabem com ele!

Chumbo no coração!

Que não sobre nem um tremor!

1620 No final das contas -

tudo tem um fim.

O tremor também acaba enfim.

O que restou

Acabou a carnificina.

A alegria está completa ${ }^{166}$.

1630 Saboreando detalhes, dispersaram-se lentos.

Só sobre o Kremlin,

os farrapos do poeta

como bandeira vermelha brilhavam no vento ${ }^{167}$.

E o céu

como antes

estrela-se $^{168}$ de lírica.

A constelação celeste

admirada fica -

a Ursa Maior trovadorou-se ${ }^{169}$.

1640 Por quê?

Para ser a rainha dos poetas?

Ursa Maior,

leve-me pelas eras-Ararates ${ }^{170}$

pelo dilúvio do céu 
como uma arca-concha!

A bordo

nave sideral

irmão ursesco

garganteio versos no rumor universal.

1650 Rápido!

Rápido!

Apresse o passo ${ }^{171}$ !

Para o espaço!

Atento!

O sol ilumina as montanhas.

Os dias sorriem do cais neste momento. 
PETIÇÃO ENDEREÇADA A...

Peço-lhe, camarada químico,

Ancora a arca.

Pra cá raios!

Cais.

Ei!

Jogue um cabo!

E acabo

de sentir com os ombros

1670 o peso dos peitoris de pedra.

O sol

secou a noite do dilúvio com seu calor.

Na janela,

encontro o dia com ardor.

Do globo somente - o monte Kilimanjaro ${ }^{172}$.

Do mapa africano somente - o Quênia.

O globo é uma cabeça calva.

Eu sobre o globo

me englobo de dor.

1680 O mundo

gostaria

de patabraçar ${ }^{173}$ os peitos-montanhas

neste monte ${ }^{174}$ de dor.

Para que dos pólos,

por todas as moradias,

role a lava pétrea e foguista,

é assim que eu gostaria de cair no choro,

urso-comunista.

Meu pai

1690 é um nobre de quatro costados,

a pele das minhas mãos é terna 
Talvez,

beba os dias com versos num trago,

e sem nunca ter visto um torno.

Mas com a minha respiração,

com as batidas do coração,

com a voz,

com cada ponta de cabelo

arrepiado de medo,

1700 com os buracos das narinas,

com os pregos dos olhos,

com os dentes arreganhados na rosnadura ferina,

porcoespinho $^{175}$ a pele,

com as sobrancelhas unidas em ira,

com um trilhão de poros,

literalmente -

com todos os poros

no outono,

no inverno,

1710 na primavera,

no verão,

de dia,

no sono

não aceitarei,

odeio isto

tudo.

Tudo

o que em nós

está cravado pelo passado de escravidão,

1720 tudo,

enxame mesquinho,

entranhado no dia-a-dia

até no nosso

regime bandeirrubro ${ }^{176}$.

Não darei o gostinho 
de ver

que calei meus versos com um tiro .

Não cantarão tão cedo

o réquiem ao meu talento.

1730 Podem me matar

emboscada na esquina

com uma faca talvez.

Os D'Anthès ${ }^{177}$ não mirarão a minha fronte.

Quatro vezes envelheço - quatro vezes ${ }^{63}$

rejuvenesço,

até que a morte me apareça defronte.

Onde quer que eu morra,

morrerei cantando.

Em qualquer buraco enterrado,

1740 sei -

com mérito estou deitado.

com os jacentes sob a bandeira vermelha.

Mas seja qual for a minha sorte -

a morte é a morte.

Terrível - não amar,

terror - não ousar.

Por todos - uma bala,

por todos - uma faca.

E para mim,

quando será minha vez?

E para mim o quê, então?

Talvez,

lá nas profundezas da infância,

encontrarei

dez dias suportáveis.

E quanto aos outros?!

Para mim seria suficiente!

${ }^{63}$ Fotomontagem 7 (Anexos, p. 232). 
Mas não.

Vejam -

1760 não há nada à minha frente!

Se eu acreditasse no além!

Fácil viagem experimental.

Basta

apenas estender a mão -

a bala,

num piscar de olhos,

traça retumbante o caminho mortal.

O que posso fazer,

se eu

1770 com toda a pressão,

com a plenitude do coração,

nesta vida,

neste

mundo

tinha

e tenho fé.

Prolonga a espera se é a sua intenção -

vejo claro,

claro até a alucinação.

A tal ponto que,

$$
\begin{aligned}
& \text { tenho a sensação - } \\
& \text { somente me soltando }
\end{aligned}
$$

dessa rima,

irrompo

1790

pelo verso

na vida sonhada. 
Eu me pergunto -

$$
\text { é esta? }
$$

$$
\text { É aquela?! }
$$

Vejo,

vejo claro e detalhado.

Ar no ar,

pedra sobre pedra,

inacessível ao perecível e à deterioração,

1800 irradiante

eleva-se sobre os séculos

a oficina humana da ressureição ${ }^{178}$.

Ali está ele,

o genial

$$
\text { calmo químico }^{179} \text {, }
$$

diante da experiência franziu a testa.

Do livro -

"Toda a terra"

um nome desenterra.

1810 Século XX.

Quem ressuscitar?

- Tem o Maiakóvski aqui...

Procuremos alguém mais brilhante -

o poeta não é belo bastante. -

Eu gritarei

daqui mesmo,

da página atual:

Não vire a página!

$$
\text { Ressuscite-me }{ }^{180 !}
$$

Põe dentro de mim um coração! 


$$
\begin{aligned}
& \text { Super sangue }^{181} \text { - } \\
& \text { até as últimas veias. }
\end{aligned}
$$

No crânio, crave o pensamento-arpão!

Não vivi meu montante de vida terrena,

1830 na terra

não amei o bastante.

Tinha 2 metros de altura.

De que me serviu essa altura?

Uma pulga teria mais arrojo.

Rangendo a pena no quarto em clausura,

dobrado feito óculos no quarto estojo ${ }^{182}$.

O que quiserem, vou fazer de graça -

limpar,

lavar,

vigiar,

pra lá e pra cá correr,

varrer.

Eu posso servi-los

nem que seja como concierge.

Vocês têm concierges?

Eu era alegre -

que sentido tem ser alegre,

se a nossa dor não tem saída?

Atualmente,

se mostram os dentes,

é só para atacar,

$$
\text { para }
$$

rosnar.

A qualquer momento -

sofrimento

ou falta de alegria...

Pode me chamar!

Uma piada vem sempre a calhar.

$\mathrm{Eu}$, com charadas de hipérboles, 
vou diverti-los,

brincando com os versos.

Eu amei...

Não vale a pena revirar o passado.

Dói?

Assim seja...

Viva e valorize a dor.

Eu amo também os bichos -

$$
\text { vocês }
$$

1870 têm

zoológicos ${ }^{183}$

Posso ser o tratador?

$\mathrm{Eu}$ amo os bichos.

Se vejo um cachorrinho -

lá perto da padaria tem um -

todo pelado,

com fome, -

estou disposto

a arrancar meu próprio fígado rapidinho.

1880 Não faz mal, querido,

come!

Talvez,

quem sabe,

um dia,

1890

por uma alameda,

ela $^{64}-$

${ }^{64}$ Fotomontagem 8 (anexos, p. 233). 
que amava os animais -

também entrará no zoológico,

sorrindo,

assim

como está lá na foto sobre a mesa ${ }^{184}$.

Ela é bonita -

na certa vão ressuscitá-la.

O século trinta

1900

superará o bando

de bagatelas que dilaceram o coração.

Nosso amor incompleto ${ }^{185}$

preencheremos

nas noites inumeráveis com a estrelidão ${ }^{186}$.

Ressuscite-me

nem que seja

porque

sou poeta

e te esperava,

1910

recusando o absurdo usual.

Ressuscite-me ${ }^{187}$

que seja só por isto!

Ressuscite-me -

quero viver a vida até o final!

Para que o amor não seja escravo

de casamento,

luxúria,

pão,

Maldizendo as camas,

1920

afastando-se do fogão, ${ }^{188}$

para que o universo se revista de amor.

Para que no dia,

em que envelhecer de dor,

não suplique como mendigo.

Para que 
ao primeiro grito:

$$
\text { - Camarada }{ }^{189} \text { ! - }
$$

a terra atenda num giro.

Para não

1930 viver pelos buracos da morada.

Para que

a família

seja,

após essa era que se encerra,

o pai,

no mínimo o mundo,

a mãe, - no mínimo a terra 


\section{I.3. Notas explicativas e comentários à tradução}

${ }^{1} \mathrm{O}$ título remete a uma expressão empregada por Raskólnikov, personagem do romance Crime e Castigo, de Fiódor M. Dostoiévski, quando se refere ao assassinato da velha usurária. O assassino emprega o pronome indefinido eto / это, em português "isto", para evitar a abordagem direta de seu crime. Apenas no final do poema de Maiakóvski aparece explicitamente a palavra liubóv' / любовь, "amor". Defendendo uma revolução também nas relações amorosas e apontando para o desgaste do tema na poesia, o poeta reconstrói ao longo do poema narrativo o caminho para a revelação de uma nova forma de amar, menos egoísta e mais solidária..

2 Trata-se da primeira seção do poema, uma espécie de prólogo em que Maiakóvski introduz o tema sem nomeá-lo e vale-se do paralelismo do verso "Este tema... " (eta teта... / это тема...) para enumerar suas características: é pessoal, banal, parece fácil, mas modificará tudo, até o alfabeto.

${ }^{3} \mathrm{O}$ verbo original é perepét' / перепеть. O prefixo pere- / пере- acrescido ao verbo pét' / петь, "cantar", atribui-lhe o sentido pejorativo de "cantar exaustivamente".

${ }^{4}$ Primeira das muitas referências a animais do poema: esquilo, porco, urso, frango, galinha, pinto, aranha, rã, porco-espinho e cachorro compõem um verdadeiro bestiário. Ripellino nota que "na obra de Maiakóvski os animais voltam com frequência". Cf. Ripelli, A. M. Maiakóvski e o Teatro de Vanguarda. São Paulo: Perspectiva, 1971, p. 182. Jakobson comenta que "o terrestre eterno é o sonho de Maiakóvski [...] e sua expressão máxima é o culto sincero aos animais e à sua sabedoria." Cf. Jakobson, R. A geração que esbanjou seus poetas. São Paulo: Cosac Naify, 2006, p. 33.

${ }^{5}$ Embora Maiakóvski fosse ateu, aparecem diversas alusões religiosas e mitológicas no poema. Além de Buda, nessa mesma seção, haverá uma referência ao deus romano da guerra, Marte. Deus aparece sempre grafado com inicial minúscula e pertencente ao discurso da família burguesa. Jesus também é mencionado, mas aqui ele é, na verdade, um Komsomol (ver nota 87). Segundo Schnaiderman, "a tradição religiosa ocorre aí com muita frequência e mesmo quando ele zomba dessa tradição, zomba com pleno 
conhecimento da matéria.” Cf. Schnaiderman, B. A poética de Maiakóvski. São Paulo: Perspectiva, 1971. p. 48. O elemento religiosso é muito forte, ainda que de forma blasfema. A luta com Deus é um dos temas dominantes da obra do poeta. As "figuras, acontecimentos, parábolas da Bíblia recorrem em seu canto com insistência obsessiva", sobretudo nas peças Tragédia e Mistério-Bufo e nos poemas Nuvem de Calças, O Homem, e Sobre Isto. Cf Ripellino, A. M, op. cit. p. 52.

${ }^{6}$ O termo noj / нож, "faca" é empregado inúmeras vezes no poema. Parece ser uma referência ao poema Balada da prisão de Reading, de Oscar Wilde, título da próxima seção. Sobre tal relação, ver nota 22. Há menção a outras armas, como fuzis, pistolas e canhões.

${ }^{7} \mathrm{Na}$ mitologia romana é o deus da guerra. No panteão grego chamava-se Ares. Na Odisseia, de Homero, Ares mantinha uma relação adúltera com Afrodite, a deusa da beleza e do amor na mitologia grega (Vênus entre os romanos). A união do amor e da guerra foi um tema muito explorado pelos pintores, dentre eles Botticelli na pintura "Vênus e Marte".

${ }^{8}$ O termo empregado é, na verdade, um neologismo, serdtseliúdy / сердцелюдый, fusão de serdtse / сердце, “coração" е liúdi / люди, "pessoas, adjetivo correspondente a "pessoa que tem um coração". Optamos por não recuperar o neologismo neste verso, com a intenção de compensar em outro momento.

${ }^{9}$ No original temos pridiot / придёт, "chegará, virá". Vários verbos desta seção estão no aspecto perfectivo, denotando o futuro, por questões de sonoridade e preservação do tom do texto, fluido em russo, decidimos empregar o presente do indicativo, que em português também é capaz de expressar uma ação futura iminente. Segundo Câmara Jr., "(...) a oposição entre presente e futuro pode sofrer neutralização, estendendo-se o uso do presente para os fatos futuros (...)". Cf. Câmara Jr., Joaquim Mattoso. Dicionário de linguagem e gramática. Petrópolis: Vozes, 1978, p. 199.

${ }^{10} \mathrm{O}$ verbo skresti / скрести significa "arranhar". "Arranhar o papel" pode ser interpretado como "escrevinhar", escrever tolices ou escrever mal. Talvez o mutilado seja aquele que 
não consegue dominar as palavras e pode apenas arranhar o papel. Preferimos "fira" para manter o som "i" insistente no original.

${ }^{11}$ Riabit' / рябит, "reflete, rebate". Optamos por "rebate", pois além de ser um termo também empregado para referir-se à luz, possui uma conotação de desafio que "refletir" não tem; como se as linhas da poesia voltassem para o sol e lhe dessem uma resposta. $\mathrm{O}$ sol é uma imagem recorrente na poesia de Maiakóvski, como no diálogo com o astro em A Extraordinária Aventura Vivida por Vladímir Maiakóvski no Verão na Datcha (trad. de Augusto e Haroldo de Campos e Boris Schnaiderman). Pode-se pensar numa relação de enfrentamento e questionamento da literatura russa canônica - Púchkin era considerado o "sol" da poesia russa. Já em 1913 a peça futurista Vitória sobre o Sol traz à baila o astro.

12 Alusão aos bilhetes que Maiakóvski e Lília Brik trocavam, por intermédio de sua cozinheira, durante o período de separação em que foi composto o poema.

${ }^{13}$ Istina / истина é um termo de difícil tradução. Seria "verdade absoluta", optamos por "pura", pois não fere o sentido e coaduna com a solução dada à tradução de krasota / красота, "beleza" como "formosura" mais adiante. Apesar de não haver rima no original, decidimos compensar nesses versos outras perdas eventuais.

${ }^{14}$ Em russo perekladnoi kisti raskisteny / перекладной кисти раскистены, “palmas espalmadas como viga". Criamos um neologismo "viguespalmadas" para compensar perdas em outras passagens.

15 Pode-se interpretar como a cartilha de alfabetização. O tema é tão complexo que desgastará o alfabeto e transformará até o abecedário em algo difícil.

${ }^{16}$ O Monte Kazbek, situado na Geórgia, terra natal de Maiakóvski, perto da fronteira com a Rússia, é uma das maiores montanhas do Cáucaso, com 5047 metros. É um elemento muito presente em mitos e tradições locais. Seu nome em georgiano significa "montanha de gelo", referência importante no poema. Thomson analisa a recorrência da imagem das montanhas em Maiakóvski e a relaciona com a questão temporal. Em primeiro lugar, as montanhas impõem um limite ao alcance da visão, um paralelo com a perda das perspectivas em relação ao futuro. Em segundo, simbolizam os percalços no caminho a 
trilhar em direção ao porvir. Somente o poeta é capaz de ultrapassar a obstrução e ver além das montanhas: ora ele atinge proporções hiperbólicas, ora é capaz de voar, ora ocupa o lugar do sol e se torna onisciente. Cf. Thomson, R. D. B.."Mayakovsky and his time imagery"("Maiakóvski e seu imaginário do tempo"). In: The Slavonic and East European Review, Vol. 48, No. 111. London: Modern Humanities Research Association and University College London, School of Slavonic and East European Studies Stable, abril de 1970, pp. 181-200. URL: http://www.jstor.org/stable/4206198, p. 185.

17 Optamos pela alternância das formas de tratamento "tu" e "você" para ressaltar a polifonia do poema. Nesta seção, o "tema" emprega "tu", mais altissonante, enquanto o eu-lírico interpela o leitor com "você", mais corrente, como era a linguagem de Maiakóvski. Aliás, a colocação pronominal e a formação do modo imperativo ao longo do poema, nortearam-se mais pelo tom de oralidade do que pelos preceitos da gramática normativa.

18 Neologismo krasnochiolkii / красношелкий, formado a partir de krasny / красный, "vermelho, escarlate" е chiolk / шёлк, "seda". Optamos por escarlate para rimar com estandarte no verso anterior, o que porta a bandeira (znamenostsem / знаменосцем).

${ }^{19}$ stala blizka / стала близка, literalmente "tornar-se próximo", é uma expressão que pode significar envolvimento amoroso, traduzimos como "tornar-se íntimo" para tentar manter a duplicidade.

${ }^{20}$ Neologismo molotoboets / молотобоец, "martelo" e "lutador".

${ }^{21}$ O termo lbov / лбов, "fronte", prenuncia, com a sonoridade, o tema que não é dito, liubov' / любовь, "amor". Na incapacidade de recuperar tal jogo em português, optamos por um termo que rimasse com amor e expressasse o sofrimento. Cada verso é tão doloroso quanto chocar a cabeça em desespero contra a parede. Comentários adicionais acerca dessa solução serão fornecidos na próxima parte.

${ }^{22}$ Única obra de Oscar Wilde no período entre a sua prisão em 1885 e sua morte no exílio em 1900. O poema fala sobre um prisioneiro condenado por haver assassinado a amada por ciúme. Maiakóvski teria ficado muito impressionado com o poema que lera em russo, 
traduzido pelo poeta V. Briússov. O tema é o assassinato da pessoa amada, como ilustra o trecho abaixo:

Yet each man kills the thing he loves

By each let this be heard,

Some do it with a bitter look,

Some with a flattering word,

The coward does it with a kiss,

The brave man with a sword!

Some kill their love when they are young,

And some when they are old;

Some strangle with the hands of Lust,

Some with the hands of Gold:

The kindest use a knife, because

The dead so soon grow cold.

Segundo ele, todos matam a pessoa amada, de uma forma ou de outra, o mais gentil com a faca, em função da rapidez. Conforme a nota 6, a "faca" é um elemento recorrente em Sobre Isto.

O livro L'amore è il cuore di tutte le cose (O amor é o coração de todas as coisas), organizado por B. Jangfeldt, reúne a correspondência entre Lília Brik e Maiakóvski. Na carta a Lília de 19 de janeiro de 1923, durante o período de confinamento e separação, ele escreveu no cabeçalho "Moscou. Prisão de Reading" e assinou com o habital desenho de um cachorro, mas desta vez atrás das grades e com a seguinte legenda:

Teu cachorrinho

que é também Oscar Wilde

que é também o prisioneiro de Chillon

que é também: estou sentado, atrás das grades, na prisão [...] 


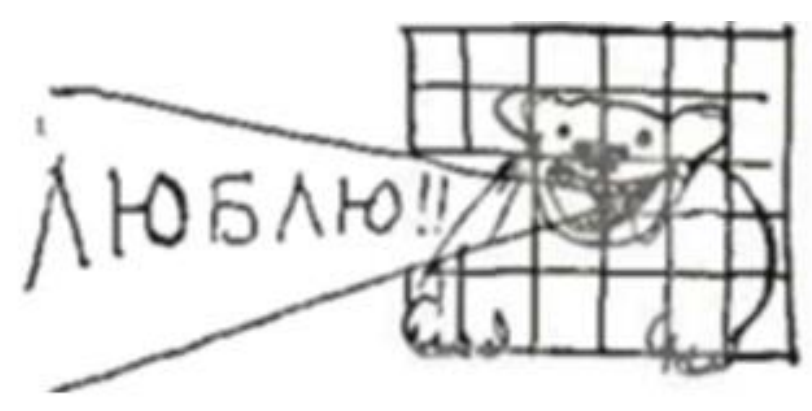

Cf. Jangfeldt, B (org.). L'amore è il cuore di tutte le cose. Vicenza : Neri Pozza, 2005, p. 160.

The prisoner of Chillon (1816) é um poema narrativo do escritor inglês romântico Lord Byron sobre o cárcere de François Bonivard de 1532 a 1536.

${ }^{23}$ Rio, de 74 quilômetros de comprimento, no noroeste da Rússia cuja nascente localizase no Lago Ládoga e foz no Golfo da Finlândia. Atravessa a cidade de São Petersburgo.

${ }^{24}$ Trata-se de um longo poema de Maiakóvski, datado de 1916, mas provavelmente concluído em 1918, portanto cerca de cinco anos antes de Sobre Isto, como figura na primeira versão do poema, segundo Jakobson. Na versão posterior, Maiakóvski alterou deliberadamente a data e situou a obra sete anos antes de Sobre Isto. Jakobson aponta para a incorreção da data que consta nas obras completas de Maiakóvski: "Quando, no final de janeiro de 1918, Maiakóvski leu o poema a alguns escritores, referiu-se a ele como 'uma obra recém acabada'.” Cf. Jakobson, R. Russie, Folie, Poésie. Paris, 1986, p. 154 , nota de fim.

A epígrafe foi extraída da penúltima parte, intitulada "Maiakóvski pelos séculos". A referência à sua própria obra é comum nos seus poemas, como aponta Jakobson em $A$ geração que esbanjou seus poetas, p. 13:

A obra poética de Maikóvski, desde os primeiros versos em Bofetada no gosto público até as últimas linhas, é única e indivisível. É o desenvolvimento dialético de um único tema. Um sistema simbólico extremamente unificado. O símbolo, lançado uma vez como alusão, desdobra-se e mostra-se em seguida sob perspectiva diferente. Por vezes, o próprio poeta realça precisamente essa relação entre seus poemas, por meio de referências a obras anteriores (no poema 'Sobre Isto' [1923], por exemplo, ele remete a 'O homem' [1916], e daí aos poemas líricos iniciais). 
A relação do Maiakóvski de Sobre Isto e o de sete anos antes é motivo dominante no poema e diversos elementos do primeiro poema são retomados: o suicídio, o rio Nevá, a ponte, a bala e a lâmina, o gelo e o calor, o ciúme...

${ }^{25}$ A balada é uma forma popular, muito empregada em poemas narrativos.

${ }^{26}$ A sonoridade deste trecho lembra a o poema Balalaica (1913), de Maiakóvski.

Balalaica

[budto laiem oborvala

skrípki bala

laica]

[s laiem oborvala]

oborvala [s laiem]

[láiki bala]

láicu bala

laica

Балалайка

[будто лаем оборвала

скрипки бала

лайка]

[с лаем оборвала]

оборвала [с лаем]

[лайки бала]

лайку бала

лайка

${ }^{27}$ Rua de Moscou onde morava Maiakóvski. Lá ele ficou enclausurado durante os dois meses de separação, compondo Sobre Isto. Atualmente é o Museu Maiakóvski. São inúmeras as referências a endereços, cidades e elementos geográficos no poema. Maiakóvski reconstrói com precisão os trajetos do poema.

${ }^{28}$ Rua de Moscou, endereço dos Brik.

${ }^{29}$ No original havia apenas o pronome "ela", inserimos "amada" para rimar com balada.

${ }^{30}$ A separação de Lília Brik e o consequente isolamento do poeta começaram em 27 de dezembro de 1922, à época do natal. Segundo Thomson a primeira versão apresentava como referência temporal o ano novo. O poeta teria modificado a data para a noite de 
natal, salientando, assim, seu ódio às tradições burguesas e religiosas. Cf. Thomson, R. D. B. op. cit., p. 194.

${ }^{31}$ Diálogo com o leitor. É como se o eu-lírico respondesse a um possível questionamento. As rimas fáceis em “-ão" recuperam o tom popular.

${ }^{32}$ Referência ao fio do telefone. Há um jogo sutil com a expressão “estar por um fio”.

${ }^{33}$ Os dois raios vermelhos cruzados eram o símbolo da companhia telefônica sueca Erickson.

${ }^{34}$ Verbo omolnili / омолнили, formado a partir do prefixo o- (ao redor) e do substantivo mólnia / молня, "cobriram de raios", aproximadamente, em português.

35 A personificação é um tropo recorrente na poesia de Maiakóvski. Ela é responsável pelo esmaecimento das fronteiras entre seres animados e inanimados. Em " $\mathrm{O}$ teatro de Maikóvski: mistério ou bufo?”, Cavaliere aponta a conflituosa convivência entre seres reificados e objetos estranhos, "prontos a se sublevar contra os homens" na peça Tragédia. Tal motivo reaparece em outras obras. Cf Cavaliere, A. "O teatro de Maikóvski: mistério ou bufo?". In: Teatro Russo. Percurso para um estudo da paródia e do grotesco. São Paulo: Humanitas, 2009, p. 275.

${ }^{36}$ Referência a um fato real, segundo um bilhete da primeira metade de fevereiro de 1923 , enviado por Lília: “Querido Volódienka, estou doente. Estou com 38,1. De cama. Como você está? Um beijo. Lília” Cf. Jangfeldt, B (org.), op. cit., p. 164.

${ }^{37}$ Rua no trajeto entre o apartamento de Maiakóvski e o dos Brik.

${ }^{38}$ Número real do telefone de Lília Brik.

${ }^{39}$ Há um jogo duplo entre o pernil de porco e o corpo feminino.

${ }^{40} \mathrm{O}$ correio central localizava-se na rua Miasnítskaia. 
41 Ataques violentos e destruidores cometidos geralmente contra minorias étnicas. $\mathrm{O}$ termo vem do russo "погром" е internacionalizou-se após o massacre no sul da Rússia entre 1881-1884, que levou à emigração maciça de judeus.

${ }^{42}$ Mescla ser vivo e inanimado.

43 No original havia v'iuchka / вьюшка, "tampa de chaminé”. Sacrificamos o termo quotidiano para ganhar em sonoridade, mas mantivemos certa relação metonímica ao empregar o material "aço".

${ }^{44}$ Referência à figura do padrinho do duelo, responsável pela troca de mensagens dos contendentes.

45 A cozinheira da casa dos Brik era Anna F. Gubanova, retomada adiante como “Annúchka". Sua foto aparece na fotomontagem 2 de A. Ródtchenko (ver anexos, p. 227).

46 Tratamento mais informal do nome e patronímico de Maiakóvski, Vladímir Vladimírovitch.

${ }^{47}$ Uma das dificuldades de tradução da língua russa é a recuperação da marca de gênero dos verbos no passado. Nesse caso, optamos por empregar o pronome pessoal para esclarecer que se tratava de uma mulher, no caso, a cozinheira.

${ }^{48}$ Referência ao duelo mortal entre Púchkin e o suposto amante de sua esposa, o oficial francês Georges D’Anthès, em 1837.

49 trogloditch'ei / троглодичьей: adjetivo criado a partir do substantivo troglodit / троглодит, "troglodita". Tentamos seguir o mesmo processo de formação para criar "trogloditesco"

${ }^{50}$ No original "VTSIK", sigla de "Comitê Executivo Central do Soviete Panrusso". departamento especial do governo no início da União Soviética. 
${ }^{51}$ Referência ao Programa de Erfurt do Partido Social-Democrata alemão, aprovado em outubro de 1891, durante um congresso em cidade homônima na Alemanha. O programa declarou a morte do capitalismo e reiterou a supressão da propriedade privada dos meios de produção.

${ }^{52}$ No original, Izvestiia / Известия, jornal com o qual Maiakóvski colaborava, um dos mais importantes da URSS. Optamos por "jornal" para garantir a rima com "estival", alguns versos antes.

${ }^{53}$ Neologismo razmedvedil / размедведил, prefixo que denota transformação $\mathrm{raz}$ / раз е verbo medvedit' / медведить, "ursar", criado a partir do substantivo medved'/ медведь, "urso" em português.

${ }^{54}$ Cf. Khardjev, N. "Images d'un bestiaire”. In: La Culture Poétique de Maïakovski. Lausanne : L'Age d'Homme, 1982, pp. 280-1 : a primeira metamorfose aparece no poema satírico E assim tornei-me um cachorro (1915), em que "o poeta, perseguido pela sociedade burguesa e vulgar que o cerca, transforma-se subitamente em cachorro". Ele prossegue: "encontramos metamorfoses fantásticas do poeta nas seguintes obras : 1917: À Rússia (um avestruz), 1922: A Quinta Internacional (um homem-ganso [...]); e no poema de 1923, Sobre Isto (o homem-urso)."

Ripellino também aponta essas e outras transformações “em 'Rossii’ (À Rússia, 1916), num avestruz azul com plumas de estrofes, de métricas e ritmos; em 'Piáti Internazional' (A quinta Internacional, 1922), num fabuloso 'homem palmípede', e no poema 'Pro Eto' (Disto, 1923), [...], num urso.”. Cf. Ripellino, A. M. op. cit., p. 182.

Segundo Jangfeldt, a referência da metamorfose é o poema Parque de Lili, de Goethe, dedicado a Lili Schöneman. Cf. Jangfeldt, B. La vie en jeu. Paris: Albin Michel, 2010, p. 246. No poema, Lili é uma fada que cuida de um jardim zoológico. Seu maior admirador é um urso selvagem que a observa e idolatra da floresta. Lili domina e aprisiona o urso apaixonado. A imagem do urso repete-se na própria obra de Maiakóvski, por exemplo, no poema Jubileu (1924).

${ }^{55}$ Balchin era o sobrenome de um vizinho de Maiakóvski na Passagem Lubiánski. 
${ }^{56}$ Introduzimos o neologismo "ursamente" no lugar de "como aqueles [ursos]" (kak tel kak te), para garantir a rima, prevista nos manuscritos, com kagtei / кагтей, "unhas", transformado na expressão "unhas e dentes".

57 No original neologismo vzmedveditsa / взмедведиться. O prefixo $v z$ / вз pode significar elevação. Medved / медвед remete a "urso" (ver nota 53). Ведиться pode ser um jogo sonoro com o verbo videt' / видеть, que compõe a expressão videt' son / видеть сон, "sonhar". Literalmente algo como "sonhar em levantar voo como urso".

${ }^{58}$ A água é um elemento recorrente na obra de Maiakóvski, por exemplo, o dilúvio em Mistério-Bufo. Os cataclismos têm a conotação de uma revolução.

59 Optamos pela unidade de medida "quilômetro" em vez da russa "versta", antiga unidade itinerária russa, equivalente a 1.067 metros.

${ }^{60}$ Maior lago europeu, cuja área total é de 14.7010 quilômetros quadrados. Situa-se na República da Carélia, no noroeste da Rússia, próximo à fronteira com a Finlândia.

${ }^{61}$ Maiakóvski cria várias palavras compostas no mesmo campo semântico: almofadagelo, almofada glacial, almofada-balsa, gelo-almofada. Em alguns versos decidimos criar neologismos para compensar perdas em outras passagens: balsalmofada e gelalmofada. Em outros, respeitando o princípio da economia, mantivemos a característica do original.

62 Neologismo likhoradius' / лихорадюсь, verbo formado a partir do substantivo likhoradka / лихорадка, “febre”.

63 O "homem de sete anos atrás" é o próprio Maiakóvski no poema O Homem (19161917), inédito em português. Os cerca de mil versos dividem-se em: "O nascimento de Maiakóvski", "Vida de Maiakóvski", "Paixões de Maiakóvski”, “Ascensão de Maiakóvski”, "Maiakóvski no céu”, “O retorno de Maiakóvski”, "Maiakóvski pelos séculos", "O último". O poema conclui-se com um tom de desespero perante os poderes do dinheiro e das mesquinharias do quotidiano. A Revolução de Outubro avivou a esperança do poeta, mas em Sobre Isto percebe-se um balanço negativo das mudanças até então alcançadas. 
${ }^{64}$ Adjetivo criado a partir do numeral "cem", sto / сто, е do substantivo “andares", etajnyi / этажный: stoetajnyi / “стоэтажный”.

${ }^{65}$ Lapliú / лаплю: verbo criado a partir do substantivo lap / лап, "pata”.

${ }^{66} \mathrm{O}$ poeta encontra seu duplo: ele mesmo sete anos antes. De acordo com Green, o desejo de aniquilamento desencadeia a aparição do duplo, pois "a fragilidade da unidade ameaçada, cria sua réplica como um remédio". Cf. Green, A. Prefácio de Le Double. Dostoiévski, 2006, p. 23. A passagem remete também à novela $O$ Duplo, de Dostoiévski, influenciado por Gógol ( $O$ Capote e $O$ Nariz). O protagonista Goliádkin, rechaçado da festa de seus superiores, vaga atarantado pelas ruas de São Petersburgo e tem visões do seu duplo perseguidor em uma ponte sobre o rio Nevá.

${ }^{67}$ Referência à novela Felicidade conjugal (1859), de Lev Tolstói.

${ }^{68}$ Como foi exposto anteriormente, é proposital a mescla do pronome oblíquo da segunda pessoa do singular e o pronome sujeito "você" em função do registro oral.

${ }^{69}$ No original Ispolkom / Исполком: о VTSIK, conforme nota 50.

${ }^{70}$ Referência feminina eio / eë, provavelmente, a mulher amada que ele não consegue substituir por nenhuma outra.

${ }^{71}$ Búria / буря, "tempestade, temporal”, traduzi como "borrasca" para manter a aliteração e assonância originais buria basit / буря басит, "baixo da borrasca". Trata-se de um elemento importante e recorrente na poesia russa, como no poema Búria na nebe vetchernem / Буря на небе вечернем (1842), Tempestade no се́u noturno, de Afanássii Fet.

${ }^{72}$ Referência a Notch pered Rojdestvom / Ночь перед Рождеством, Noite de Natal (1832), de N. Gógol, traduzido para o português por Paulo Bezerra. Esta obra insere-se na tradição dos sviátki, contos ambientados no período do natal. A narrativa de Maiakóvski passa-se no natal de 1922, justamente quando se separou de Lilia Brik e 
iniciou a composição do poema. Sobre Isto compartilha com a novela de Gógol o ambiente natalício e outras características dos sviátki, tais como os sonhos, os fatos insólitos e fantásticos e as catástrofes naturais. Outro mestre do gênero foi N. Leskóv.

${ }^{73}$ Mais uma referência ao universo gogoliano e aos sviátki. No artigo "Gogol dans la poésie de Maïakovski”, Khardjiev afirma que Gógol é um dos clássicos mais retomado por Maiakóvski, especialmente nos poemas longos. Segundo o crítico, Maiakóvski transforma ou desenvolve as imagens de Gógol, de quem se aproxima não apenas pela veia satírica, mas também pela inovação:

Maiakóvski apreciava nas obras de Gógol a visão poética do mundo exterior, uma língua saturada de folclore e de neologismos de uma grande riqueza expressiva, o caráter hiperbólico das comparações e o aspecto inesperado das metáforas, a dualidade dos planos em um estilo em que se mesclam o cômico e o trágico, a profusão de variedades das entonações e dos heróis que falam cada um a sua própria língua.

Khardjiev também cita o artigo de Biély "Gogol et Maïakovski” (In: La maîtrise de Gogol) que retraça as relações entre as imagens hiperbólicas de ambos e a convergência de alguns de seus princípios de criação de novas palavras. Cf. Khardjiev, N., op. cit., pp. 255-256.

${ }^{74}$ No original, versos em semi-linhas, Groen lap liub-landiia / Гроен лап люб-ландия. Na tradução "Groen / is / amor-lândia ainda não conseguimos recuperar totalmente o jogo feito pelo poeta. Primeiro ele refere-se à Groenlândia, em seguida relaciona Lapônia (Laplandiia / Лапландия, em russo) е lap / лап, "pata" (do urso). Em português não encontramos uma solução que reproduzisse o efeito de um nome de país glacial terminado em "lândia" e que remetesse a animal. Optamos por "is", para remeter à Islândia. O topônimo Liublandia aparece no roteiro cinematográfico Acorrentada pelo filme, escrito por Maiakóvski em 1918 e dedicado a Lília. O filme fala do amor não correspondido e, na última cena, o protagonista aparece num trem rumo à Liublandia, ou "terra do amor", onde mora a sua amada.

Outra solução, "pata-mor-gônia" recuperaria "pata", a referência a uma "terra gelada", a palavra amor, mas perderia a precisão geográfica - usual em Maiakóvski -, e o sufixo "lândia". Uma terceira solução ficaria geograficamente mais próxima do original, 
rimaria com "nevasca" alguns versos antes, mas não contemplaria dois países, nem recuperaria o viés animal: "a -mor-lasca".

${ }^{75}$ Grande parque moscovita, próximo à rua de Tver, ulteriormente nomeada rua Górki, artéria norte-sul de Moscou.

${ }^{76}$ Campo nos arredores de Moscou onde se realizavam festas e reuniões. Foi o palco de uma grande tragédia em 18 de maio de 1896, durante a celebração da coroação de Nicolau II. O público excessivamente numeroso e a falta de organização do evento levaram à morte de cerca de 1500 pessoas.

${ }^{77}$ Rua central de Moscou.

${ }^{78}$ No original $a-u-u-u$ / a-y-y-y, interjeição russa de quem está perdido. Em português optamos por "ei".

79 Trata-se da rua Bol'chaia Sodovaia / Большая Садовая, em Moscou. Atualmente abriga o Museu Mikhail Bulgákov.

80 "Nova Política Econômica" implementada por Lênin em 1921, cujo objetivo era introduzir algumas práticas capitalistas no regime socialista visando incentivar a economia soviética. Maiakóvski denunciou a corrupção crescente e o reaburguesamento da sociedade engendrados por essas medidas.

${ }^{81}$ Referência a Os Doze (1918), de A. Blok (1880-1921).

${ }^{82}$ No original, "coroado de lua", substituímos por "coroado de luz" para ganhar a rima com "Jesus".

83 Abreviação de Kommunistitcheskii Soiuz Molodioji / Коммунистический Союз Молодёжи, "União da Juventude Comunista", a organização juvenil do Partido Comunista da União Soviética, criada em 1918. A filiação era permitida dos 14 aos 28 anos e o objetivo era difundir os valores do partido comunista entre os jovens. Era a porta de entrada da política soviética. 
${ }^{84}$ obmotki / обмотки são as tiras de tecido enroladas ao redor do cano das botas dos soldados. Traduzimos como "ataduras" por falta de conhecimento de termo correspondente no vestuário militar em português.

85 Neologismo protsyganennom / проциганенном. O prefixo pro- / про- aqui denota exagero. Empregamos o prefixo "ultra-" para expressar o excesso.

${ }^{86}$ A romança é um tipo de poema lírico curto, de tema amoroso, composto para acompanhamento vocal e musical. Na Rússia, a romança surgiu no lastro das tendências românticas da primeira metade do século XIX. Na romança russa são muito comuns os motivos ciganos. Segundo Boris schnaiderman, a romança estava "muito em voga na Rússia até o começo do século XX”. Cf. Schnaiderman, B. Os escombros e o mito. São Paulo: Companhia das Letras, 1997, p. 226.

Nas notas à tradução de Sobre Isto, Herbert Marshall afirma que:

Os grupos musicais ciganos eram a maior expressão da nostalgia pelo passado, bem como uma tentativa de esquecer o presente no período revolucionário. Durante o período da NEP grupos e casas noturnas floresceram novamente em Moscou e Leningrado [São Petersburgo], etc.

Cf. Herbert Marshall. In: About this. Tradução de London: Dennis Dobson, 1965, nota de rodapé, p. 224.

Khardjiev e Trenin salientam o efeito derrisório que o termo "romança" lança sobre o tema do suicídio que se desenrola nesta seção. Cf. Khardjiev, N, Trenine, V. "Le travail de Maïakovski sur le poème De Ceci”. In: Khardjiev, N, Trenine, V., op. cit., p. 246.

${ }^{87} \mathrm{O}$ tema do suicídio é recorrente em Maiakóvski. Aparece em Nuvem de calças e $O$ Homem. Em Sobre Isto é um jovem Komsomol que se mata. Sete anos depois, em 1930, Maiakóvski recupera a frase "não culpem ninguém" na sua carta de despedida. "Cf. Jangfeldt, B. La vie en jeu. Paris: Albin Michel, 2010, p. 531.

${ }^{88}$ Optamos por suprimir alguns verbos desta passagem para recuperar a dualidade do sujeito. Os versos iniciais ressaltam a semelhança assombrosa do eu-lírico e do outro. A 
seguir, os verbos empregam-se no passado e, em russo, a terminação apenas indica o gênero masculino, não se pode ter certeza de quem é exatamente.

${ }^{89}$ No original kalibr / калибр, “calibre”, aqui empregado para referir-se ao tamanho da roupa, mas é interessante notar também o campo semântico das armas.

${ }^{90}$ Rua onde moravam a mãe e as irmãs de Maiakóvski, situada em um bairro popular de mesmo nome perto do centro da capital.

${ }^{91}$ No original, adjetivo plural vsekhnye / всехные, criado a partir do pronome vse / все no genitivo plural. Em vez de traduzir como "de todos", optamos por um adjetivo, embora não seja um neologismo, nem recupere a mesma raiz. De qualquer forma, "universais" recupera o sentido, rima com "pais" e antecipa a visão que o poeta defenderá da família e do amor nos versos finais.

${ }^{92}$ Discurso semelhante ao de Prissípkin no final de $O$ Percevejo.

${ }^{93}$ No original "versta". 600 verstas equivalem a cerca de 640 quilômetros, a distância entre Moscou e São Petersburgo.

${ }^{94}$ No original rodnói / родной, “querido". Substituímos por “alma”, pois é um afetivo existente em russo e para rimar com "calma" no verso seguinte, conforme o original.

${ }^{95} \mathrm{Na}$ obra de Maiakóvski, o chá é o símbolo da vida pequeno-burguesa ritualizada.

${ }^{96}$ No original a rima não é perfeita, tentamos obter o mesmo efeito com "doméstico" e "das meias".

${ }^{97}$ Aleksandra Alexéievna, nome e patronímico da mãe de Maiakóvski. Nesta passagem o nome aparece infantilizado, “Al'sandra Al'seievna”, reproduzindo a pronúncia de uma criança. 
${ }^{98}$ Rio da Europa central, com 885 quilômetros de comprimento, cuja nascente se localiza no maciço da Boêmia, na República Tcheca, e foz no mar Báltico. Serve de fronteira entre a Polônia e a Alemanha.

${ }^{99}$ Cidade no noroeste da Polônia às margens do rio Oder. Terra natal da tsarina Catarina II.

${ }^{100}$ Distrito de Moscou. Palco do ponto culminante da Revolução de 1905.

101 Rua e praça próximas do centro de Moscou. Havia um arranha-céu homônimo no trajeto do apartamento de Maikóvski à casa de sua mãe.

102 No original, neologismo. Substantivo dalekost' / далекость formado a partir do advérbio daleko / далеко, "longe". Uma possibilidade de neologismo em português seria "longeza", mas optamos pelo já existente substantivo "lonjura".

${ }^{103}$ Verbo strezvet' / стрезветь, criado a partir de trezviét' / трезветь, “tornar-se sóbrio", precedido do prefixo $s$ - / c-, "para fora, longe”. Na tradução do neologismo, empregamos o prefixo "en-" que denota "movimento para dentro". Descartamos a possibilidade de um verbo pronominal por questões de sonoridade. O movimento exógeno e a coloquialidade do registro foram garantidos pela expressão "se mandou".

104 Outra referência ao poeta A. Blok, Alegria inesperada (1907), seu segundo livro de poemas, responsável por sua popularização.

${ }^{105}$ Essa passagem é comentada por Jakobson. Segundo ele, em Sobre Isto, fica a clara a luta do poeta contra a vida quotidiana e o embate do "eu" e do "não-eu". Cf. Jakobson, R. op. cit., p. 18. Os "sem rostos" são as pessoas conhecidas envolvidas nas teias de aranha da inércia do dia-a-dia.

106 Trata-se, provavelmente, de um soldado da Guarda Vermelha. Segundo nota da tradução de Herbert Marshall, durante o período da guerra civil, os moradores dos apartamentos acomodavam um oficial soviético como garantia de certa proteção. Cf. 
Herbert Marshall. In: About this. Tradução de London: Dennis Dobson, 1965, nota de rodapé, p. 188).

${ }^{107} \mathrm{O}$ gêmeo é uma referência ao duplo primordial. Segundo Nicole Fernandez Bravo, da Antiguidade ao século XVI, tem-se o duplo como o símbolo do idêntico e do homogêneo, em que as figuras centrais são os irmãos - notadamente, os gêmeos -, os sósias e até mesmo figuras sobrenaturais. As obras desta fase têm em comum a usurpação da identidade e o desfecho que reafirma a unidade. Cf. Bravo, N. F. "Duplo". In: Brunel, P. (org.). Dicionário de Mitos Literários. Rio de Janeiro: José Olympio, 1997, p. 261. Goimard e Stragliati afirmam que "sósias e gêmeos, irmãos unidos e irmãos inimigos são a pré-história do tema do duplo”. Cf Goimard, J, Stragliati, R. In: Troubetzkoy, W. (org.). La Figure du Double. Coleção "Questions Comparatistes”. Langres: Didier Erudition, 1995, p.5.

No século XIX, expõe-se toda a dualidade do ser e "o sujeito de desejo entra em choque com a personalidade, imagem imposta pela sociedade". Cf. Bravo, N. F., op.cit, p. 275. Eis o que dará origem a temas capitais na literatura russa do século XIX, especialmente nas obras de Gógol e Dostoiévski, referências conhecidas de Maiakóvski especialmente em Sobre Isto, tais como o conflito entre essência e aparência. No poema, o duplo é o "eu" convencional do poeta, acomodado na estabilidade e no individualismo, aquele que ele não deseja ser e cuja postura ele refuta.

${ }^{108} \mathrm{O}$ inseto daria título, anos mais tarde, à obra-prima da dramaturgia de Maiskóvski. $O$ Percevejo, peça escrita em 1928 e encenada em 1929, apresenta uma visão crítica do futuro do socialismo e retrabalha vários elementos de Sobre Isto. A peça marca a "tomada de consciência sobre o momento vivido então pela Rússia, com a consolidação do sistema stalinista e a eliminação de quaisquer vozes divergentes". Nela encontram-se os "elementos típicos do teatro de Maiakóvski: o espetacular, o circense, o sarcasmo feroz, neste caso dirigido contra o aburguesamento e a kitschização suscitados pela NEP [...] e contra o ambiente que se criara, marcado pelo consumismo desenfreado." Cf Maiakóvski, V. O Percevejo. Posfácio de Boris Schnaiderman. São Paulo: 34, 2009, pp. 85-6.

O Percevejo e Os Banhos (1929) inserem-se num "contexto de perplexidade diante de um gradativo esvaziamento dos ideais revolucionários em todos os setores da vida russa na década de 1920, particularmente no âmbito da literatura e das artes”. Cf. Cavaliere, A. op. cit., p. 273. 
${ }^{109}$ Outra possível referência à novela A Noite de Natal, de Gógol. No início da narrativa aparece a "bruxa montada na vassoura" roubando as estrelas. A bruxa é um elemento muito comum nos folclores russo e ucraniano.

${ }^{110} \mathrm{O}$ rio Ienissei, com 4.093 quilômetros de extensão, é um dos maiores rios da Sibéria, ao lado do Ob e do Lena. Nasce na Mongólia e desemboca no Oceano Ártico.

${ }^{111} \mathrm{O}$ rio Ob é o quarto maior do país, com 3.650 quilômetros. A nascente localiza-se nos Montes Altai e a foz no mar de Kara.

112 No orginial stal l'dom / стал льдом, "tornou-se gelo". Optamos por “congelou” para recuperar a sonoridade inicial de "casa" e a noção de "gelo", já que não conseguimos reproduzir a rima do poema em russo.

${ }^{113}$ Gerúndio formado a partir do prefixo vy- / вы-, "movimento para fora" e o som do sino zvonia / звоня, "badalando".

${ }^{114}$ Neologismo lirovo / лирово, “à moda da lira”.

115 Alusão à peça Mistério-Bufo. A primeira versão foi escrita e encenada em 1918; a segunda, retrabalhada, estreou em 1921. Considerada a primeira peça soviética, ambas as versões foram duramente criticadas pela "tendência demasiado política e o caráter debochado do espetáculo". Cf. Cavaliere, A., op. cit., p. 279. Algumas imagens são retomadas em Sobre Isto, como o dilúvio e a arca de Noé.

${ }^{116}$ Maiakóvski faz um jogo com most / мост, “ponte”, aquela sobre o Nevá onde se dá o primeiro encontro com o duplo, e o nome de uma rua de Moscou, Kuznetskii Most / Кузнецкий Мост, rua "Ponte Kuznetski". É uma das mais antigas ruas de Moscou, localizada no centro, entre a Bolchaia Dmítrovka e a Lubiánka. Deve seu nome a uma ponte construída no século XVII e demolida no início do XIX. Sinônimo de sofisticação e modernidade, nela instalaram-se os primeiros candeeiros a gás e, mais tarde, a iluminação elétrica e a primeira central telefônica de Moscou. Passou a ser o centro financeiro da capital na segunda metade do século XIX. Símbolo da influência francesa, 
contava com inúmeras lojas de luxo de proprietários estrangeiros. Após a revolução de 1917, as lojas foram fechadas, mas com a NEP algumas reabriram.

117 Jogo para duas pessoas, cujo objetivo é obter 66 pontos a partir de combinações específicas de cartas.

118 Arnold Böcklin (1827-1901), pintor simbolista suíço. No princípio, era pintor de paisagens, introduziu gradualmente temas mitológicos e alegóricos em suas telas que apresentam com frequência uma obsessão pela morte e ambientes fantásticos. Foi influenciado pelo romantismo, sobretudo, pelo pintor alemão Caspar David Friedrich (1774-1840). Influenciou os surrealistas e alguns compositores, dentre eles Rakhmaninov que compôs um poema sinfônico inspirado no quadro "A Ilha dos Mortos".

${ }^{119}$ Obra-prima de A. Böcklin (ver nota 118), “A Ilha dos Mortos” retrata uma ilha rochosa ao pôr-do-sol, à qual o barqueiro Caronte conduz um morto que viaja em pé observando seu destino final. A pintura evoca a morte e a solidão. Houve cinco versões do quadro, quatro conservam-se até hoje em museus diversos. As reproduções do quadro estavam em voga naquela época, sobretudo nas casas pequeno-burguesas.

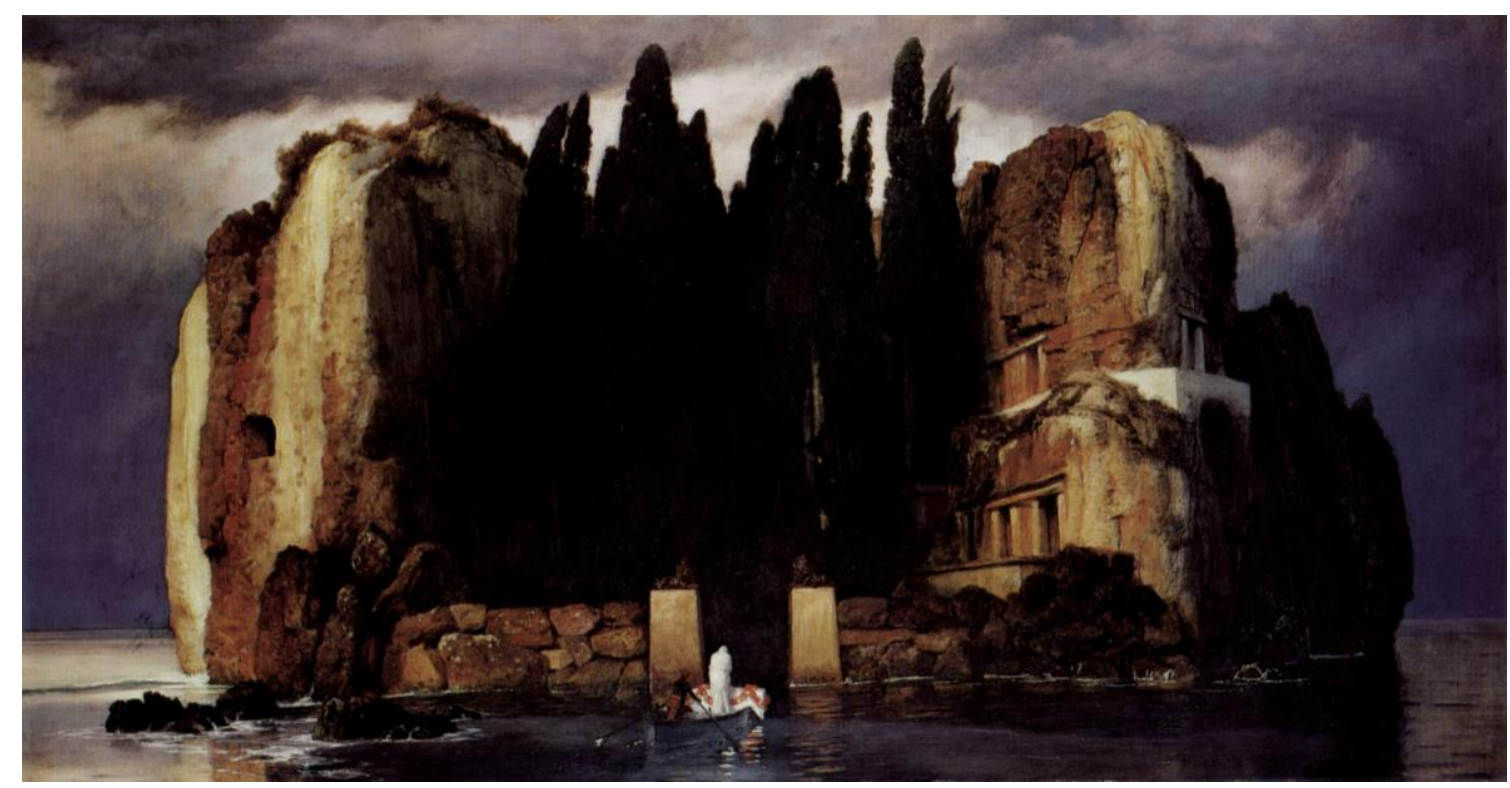

“A Ilha do Mortos” (1886), última versão, Museum der bildenden Künste, Leipzig

Fonte: http://de.wikipedia.org/wiki/Die_Toteninsel, acesso em 10 de dezembro de 2014. 
${ }^{120}$ No original polia / поля, “campos”. A substituição considerou a reprodução da rima do original e o campo semântico "paisagem geográfica".

${ }^{121} \mathrm{Na}$ verdade, as árvores do quadro de Böcklin são ciprestes. Os álamos são a árvore símbolo de Moscou.

${ }^{122}$ No original, um neologismo mertvost' / мертвость.

${ }^{123}$ Alusão ao quadro de Böcklin (ver nota 119). Caronte, segundo a mitologia grega, é o barqueiro do Hades, responsável pela travessia dos mortos entre os rios Estige e Aqueronte, divisa entre o mundo dos vivos e o dos mortos.

${ }^{124}$ Adjetivo spiachtchelobyi / спящелобый, criado a partir do gerúndio do verbo spat' / спать, “dormir", e do substantivo lob / лоб, “fronte". Invertemos a ordem e empregamos um particípio passado para obter "cabeçadormecidas". Outra possibilidade seria “dormentestas" para recuperar o particípio presente e "testa".

${ }^{125}$ Janelas do apartamento dos Brik na Vodopiany:

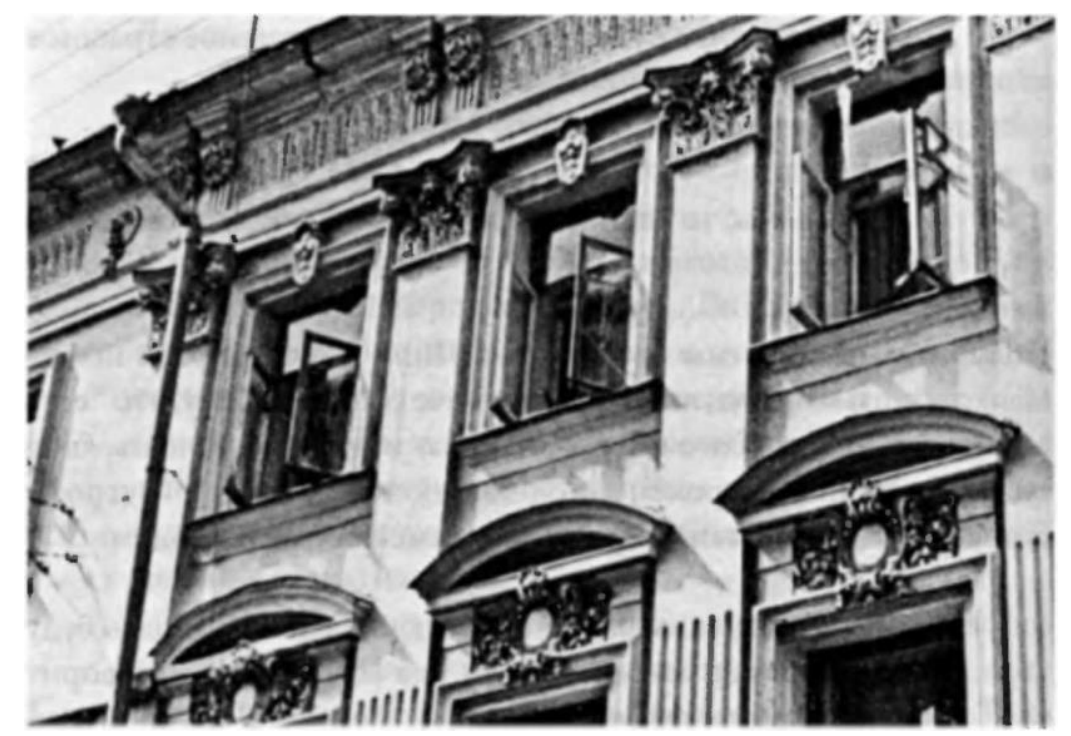

Fonte: http://coollib.com/b/166980/read, acesso em 10 de dezembro de 2014

Referência a um fato real. Durante o período de separação, Maiakóvski não deveria visitar Lília e só deveria telefonar ou escrever em caso de necessidade. Apesar do 
acordo, sabe-se que sua correspondência foi farta e, não raro, ele rondava o apartamento dos Brik no beco Vodopiáni.

${ }^{126} \mathrm{O}$ eu-lírico "joga" com as janelas, como se seus vidros formassem um baralho de cartas. Maiakóvski era um jogador inveterado, capaz de dedicar muitas horas seguidas ao vício, o que lhe rendeu muitas discussões com Lília Brik.

${ }^{127}$ No original arap / apan, "negro". Referência ao célebre antepassado negro de Púchkin, sobre o qual ele escreveu a novela Apan Петра Великого (O Negro de Pedro, o Grande). Segundo algumas pesquisas, o bisavô de Púchkin, Ganíbal, originário do Sudão Central, fora comprado em Constantinopla e dado de presente a Pedro, o Grande, em cuja corte traçou uma história gloriosa. Cf. Púchkin, A. A dama de espadas . Prosa e Poemas. Trad. de Boris Schnaiderman e Nelson Ascher. São Paulo: Ed. 34, 1999, prefácio, pp. 8-9.

${ }^{128}$ Neologismo iarkoognim / яркоогним, cujas raízes são iarkii / яркий, “claro, luminoso, brilhante" е ogon' / огонь, "fogo".

${ }^{129}$ Personagem principal do romance Crime e Castigo de F. M. Dostoiévski (ver nota 1).

130 Neologismo criado a partir do prefixo $v$ - / B-, "movimento para dentro" e do substantivo plesen'/ плесень, "mofo". O eu-lírico quer dissolver-se no mofo da parede.

${ }^{131}$ A cozinheira dos Brik, conforme nota 45.

132 Adjetivo criado a partir do substantivo one-step / уанстеп, dança de salão, oriunda dos Estados Unidos, popular no início do século XX. Posteriormente, originou o foxtrote. Para formar o neologismo, optamos pela terminação de particípio presente.

${ }^{133}$ Ritmo que originou o one-step.

${ }^{134}$ No original é um neologismo de registro coloquial, obydenchtchine / обыденщине que remete à rotina. 
135 Adjetivo kvartirovchnii / квартировшный, criado a partir do substantivo kvartira / квартира, “apartamento".

${ }^{136}$ Provavelmente é uma referência à longa "carta-diário" escrita a Lília em fevereiro de 1923, durante o período de separação. Há várias passagens da carta que figuram no poema. A carta, nunca enviada, foi encontrada no apartamento do beco Gendrikov somente após a morte do escritor.

${ }^{137}$ O termo bachka / башка, “cachola, cuca”, é coloquial.

${ }^{138}$ Cidade no noroeste da Rússia, na rota entre Moscou e São Petersburgo.

${ }^{139}$ Cidade no noroeste da Rússia na confluência dos rios Volga e Tvertsa, na rota entre Moscou e São Petersburgo.

${ }^{140}$ Cidade no noroeste da Rússia, na rota entre Moscou e São Petersburgo.

${ }^{141}$ Petróvskoie- Razumóvskoe, última estação de trem da rota São Petersburgo-Moscou.

${ }^{142}$ Estação ferroviária em Moscou.

${ }^{143}$ Adjetivo obezliublennoi / обезлюбенной, criado a partir do prefixo (o)bez- / (о)без-, “sem" е do substantivo liubov' / любювь, “amor".

${ }^{144}$ Referência ao mítico café La Rotonde no bairro de Montparnasse, na esquina dos bulevares Montparnasse e Raspail, em Paris, localização que rendeu seu nome ("rotunda" segundo o Houaiss, é uma "praça formada pela convergência de diferentes vias e onde o trânsito se processa em sentido giratório").

Inaugurado em 1911, o local era um reduto dos artistas da época, que muitas vezes trocavam pinturas e desenhos por uma refeição. Por lá passaram nomes como Picasso, Modigliani, Breton, Satie, Lênin, Trótski, Anna Akhmátova, Prokófiev, Stravínski, Diághilev, Nijínski e o próprio Maiakóvski, dentre outros. Maiakóvski visitou Paris pela primeira vez em 1922. 
O café no início do século:

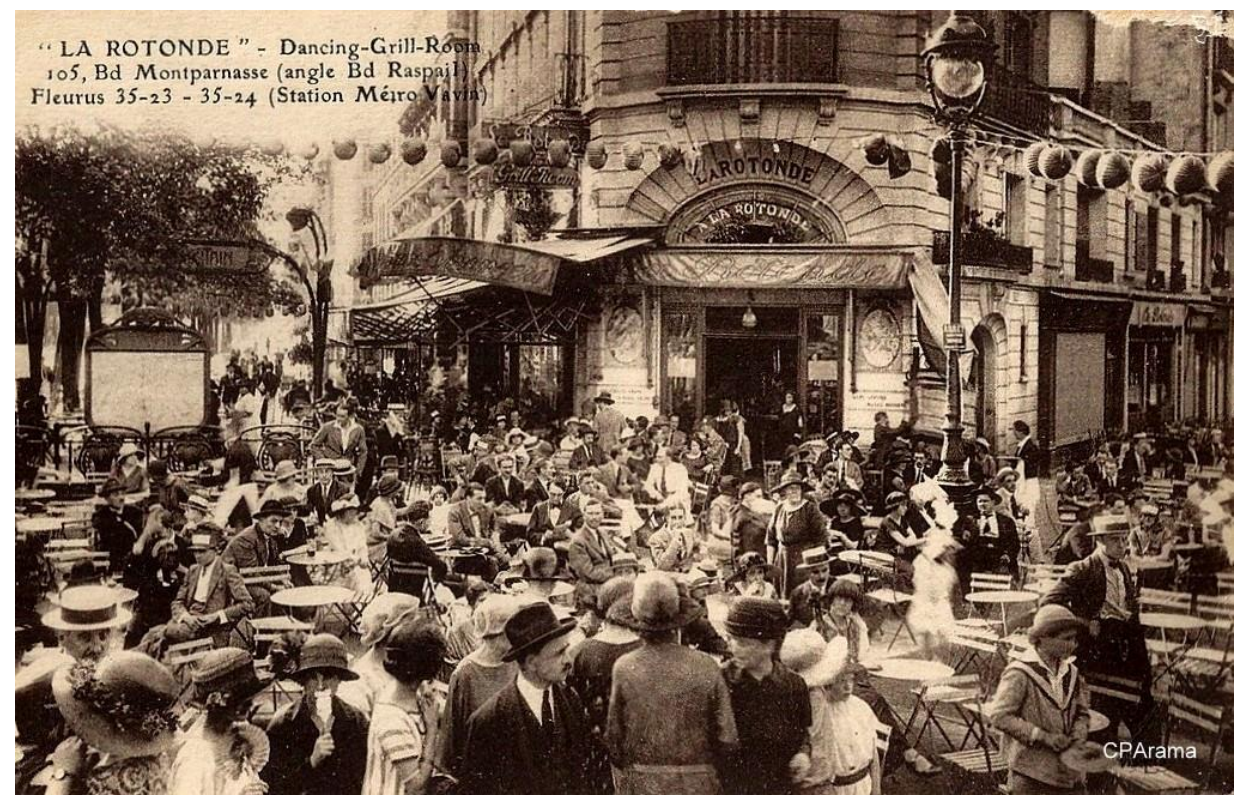

O café atualmente:

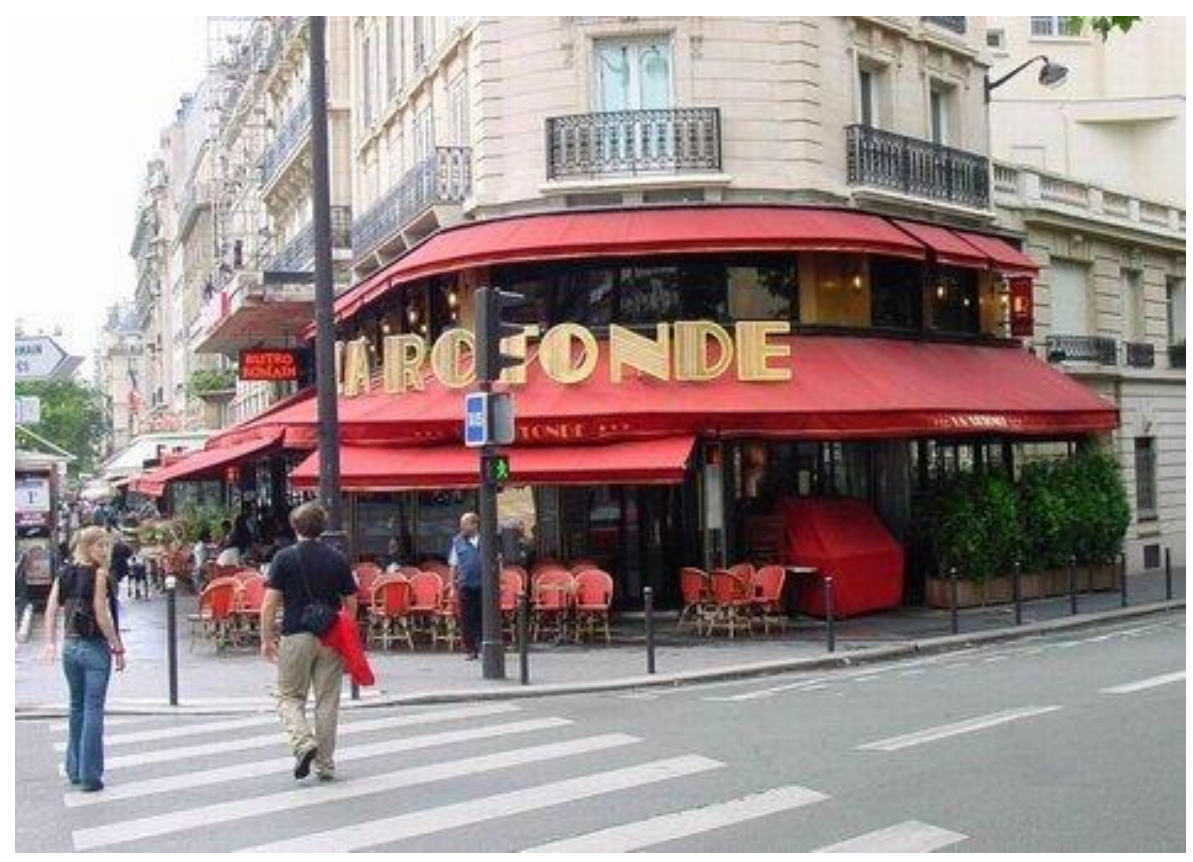

Fontes das imagens: http://paris1900.1artnouveau.com/paris14/bd_montparnasse/la_rotonde.htm e http://www.rotondemontparnasse.com/historique.htm, acesso em 23 de janeiro de 2015

${ }^{145}$ Referência irrecuperável na tradução até o momento: há um jogo entre o rio Sena, em Paris e a Sennaia Plochtchad' / Сенная Площадь, literalmente "Praça do Feno", uma das 109 
mais antigas de São Petersburgo. Seu nome tem origem no mercado de feno que havia no local na década de 1730. O local, cujos arredores eram bem degradados, aparece em Crime e Castigo (1866). Antes de ir à polícia confessar o assassinato que cometera, Raskólnikov beija o chão da praça: "Ele entrou na Siénnaia. Achava desagradável, muito desagradável deparar-se com o povo, mas ele caminhava precisamente para lá, para onde se via mais gente. [...] Ajoelhou-se no meio da praça, inclinou-se até o chão e beijou essa terra suja, com êxtase e felicidade." Cf. Dostoiévski, F. Crime e Castigo. Trad. de Paulo Bezerra. São Paulo: Ed. 34, 2007, p. 533-4. Dostoiévski, foi encarcerado na Casa da Guarda, primeiro edifício construído na praça (1818-20) por dois dias, em 1874, por ter violado as leis da censura como editor do jornal Grajdanin.

Durante o período soviético, a praça, então chamada de "Praça da Paz", foi revitalizada. No entanto, até hoje a região onde ela se localiza (oeste) é uma área de contrastes econômicos e sociais. Cf. São Petersburgo. Guia visual de bolso. São Paulo: Publifolha, 2012.

146 Neologismo ispozolotcheno / испозолочено, cuja raiz é pozolotchennii / позолоченный, “dourado". Criamos "folheadourada", baseando-nos na noção de "folheada a ouro".

${ }^{147}$ Campanário de Ivan, o Grande (Колокольня Ивана Великого), a mais alta torre do Kremlin, com 81 metros, construída em 1508. Graças à sua altura, por muito tempo, serviu como atalaia para identificar incêndios e a aproximação dos inimigos.

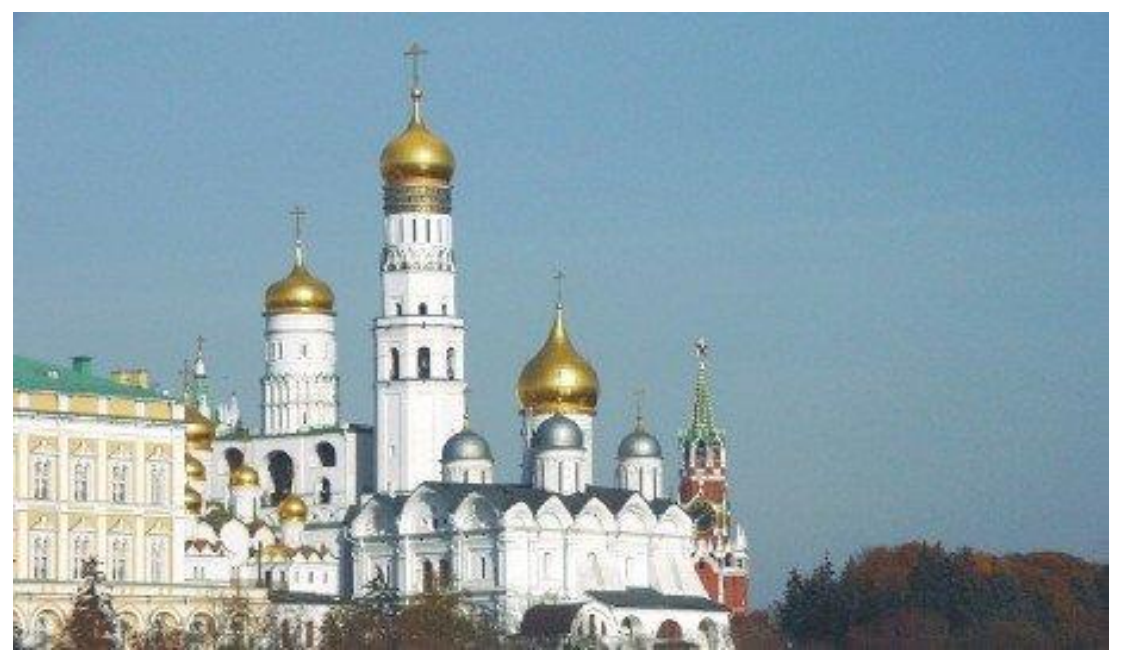

Fonte: http://portuguese.ruvr.ru/radio_broadcast/87551146/91793340/, acesso em 27 de janeiro de 2015 . 
${ }^{148}$ Verbo criado a partir do prefixo $z a$ - / 3a-, que indica o início de uma ação, movimento através, para além; e do substantivo rojdestvo / рождество, "natal". Segui o mesmo processo para criar o verbo "transnatalizar", formado pelo prefixo "trans-" análogo ao russo $z a$ - / зa- em português.

${ }^{149}$ Como Roma, Moscou desenvolveu-se sobre sete colinas.

${ }^{150}$ Desfiladeiro entre a Rússia e a Geórgia, a leste do monte Kazbek, pelo qual passa o rio Terek (ver nota 151). Única passagem natural através do Cáucaso, o local tornou-se um acesso historicamente estratégico. Foi imortalizado na literatura russa por Púchkin Viagem a Arzrum (1836), baseado em notas de uma viagem ao Cáucaso -, Liérmontov O Demônio (1837), Tamara (1841) - e outros. Aliás, a relação com o poema O Demônio ultrapassa a geografia. Nele, um demônio apaixona-se pela jovem Tamara e a seduz, mas ao beijá-la, ele a mata. Mais uma vez surge a referência ao assassinato da pessoa amada, como no poema de Oscar Wilde. Maiakóvski retomará o poema de Lérmontov em 1924, em Tamara e o Demônio.

${ }^{151}$ Um dos principais rios do Cáucaso, o Terek nasce perto do monte Kazbek, na Geórgia e desemboca no Mar Cáspio. Com 623 quilômetros de comprimento, atravessa os territórios da Geórgia e da Rússia. Aparece em Os Cossacos, de L. Tolstói. Nessa obra o nobre Oliên abandona a superficialidade de Moscou para viver na simplicidade da natureza com os camponeses.

${ }^{152}$ Expressão escolar corrente em russo.

${ }^{153}$ Em russo, gusteet notch' / густеет ночь, “a noite adensa-se”. Optamos por “noite sem luz" para rimar com "cruz" alguns versos antes.

${ }^{154}$ Montanha de 993 metros no norte Cáucaso, em Piatigorsk, cidade russa. Aparece em Um herói do nosso tempo, de Mikhail Liérmontov. Liérmontov foi morto em um duelo aos pés dessa montanha em 27 de julho de 1841, por um oficial do exército russo, Nikolai Martymov, um antigo colega da Escola de Cadetes da Guarda na qual ingressara em 1832. Outra referência importante é a lendária origem do nome "Machuk", um guerreiro 
cabardino (grupo étnico do Cáucaso pertencente aos circassianos) que lutou contra os mongóis e se suicidou pulando de um penhasco da montanha quando foi cercado pelos inimigos. Os temas do suicídio e do duelo revelam-se na escolha do local.

155 De acordo com uma nota à tradução de Herbert Marshall, trata-se de um boneco feito de papelão, cujos braços e pernas movimentam-se através de um mecanismo de fios. Era vendido nas feiras da Praça Vermelha na festa de Ramos, muito popular entre os moscovitas. Cf. Herbert Marshall. In: About this. Tradução de London: Dennis Dobson, 1965, nota de rodapé, p. 204.

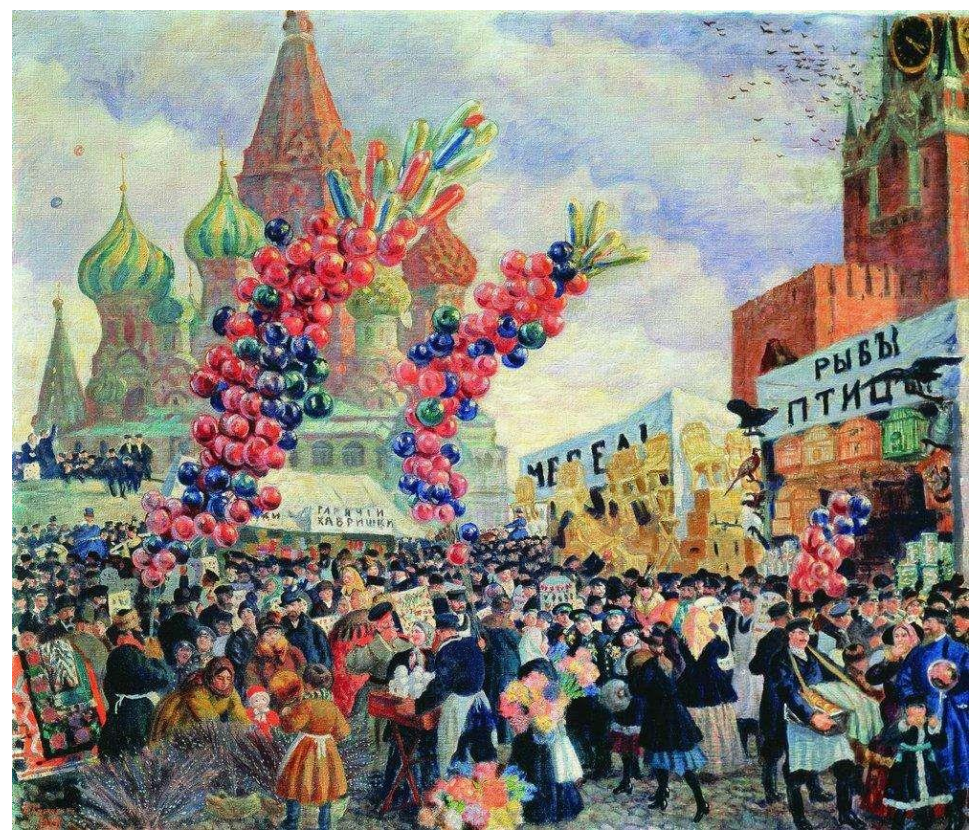

Feira de Ramos na Praça Vermelha. B. Kustodiev, 1917.

Fonte da imagem: https://ru.wikipedia.org/wiki/Вербная_неделя, acesso em 27 de janeiro de 2015.

${ }^{156}$ Agência Nacional de Detetives Pinkerton, fundada nos Estados Unidos em 1850, por Allan Pinkerton. Seus detetives eram especialistas em sufocar movimentos grevistas.

${ }^{157}$ Gesto simbólico de violência iminente.

${ }^{158}$ Em russo, pertchatotchnyi / перчаточный, adjetivo criado a partir de pertchatka / перчатка, "luva”. Optamos pelo sufixo “-oso”, que indica abundância, por questões semânticas e sonoras: "lojas luvosas". 
${ }^{159}$ Atirar a luva representa um convite ao duelo.

${ }^{160}$ Literalmente, "boato na orelha", como se a calúnia desferisse um golpe doloroso. Para conferir sonoridade ao verso na tradução e a mesma noção em português, substituímos por "boca do estômago", como se o boato fosse um soco.

161 Soldado da cavalaria ligeira. Outra referência a M. Liérmontov, incorporado ao regimento hussardo em 1834, na cidade de Tsarskoe Selo. A passagem refere-se à morte de Liérmontov no duelo (ver nota 154).

163 Trata-se da figura do poeta solitário crucificado pela incompreensão e ao mesmo tempo redentor, integrante da obra de Maiakóvski desde Tragédia (1913). Cf. Cavaliere, A., op. cit., p. 275.

${ }^{164}$ A imagem será retomada no poema Carta a Tatina Iácovleva (1928):

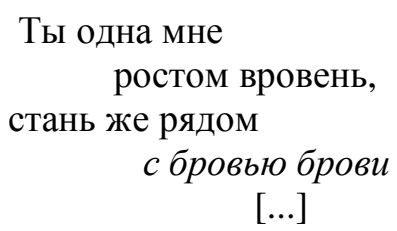

Na estatura

só você me ombreia,

fique pois, sobrancelha a sobrancelha, ao meu lado.

( Maiakóvski. Poemas. Trad. de A. e H. de Campos e B. Schnaiderman. São Paulo: Perspectiva, 2003, p. 127, grifo meu)

165 Mauser era uma fabricante alemã de armas de fogo fundada em 1870. Em 14 de abril de 1930, Maiakóvski suicidou-se com um tiro no coração usando uma pistola dessa marca. Browning é uma fabricante de armas americana fundada em 1878.

${ }^{166}$ No original klokotchet / клокочет, verbo klokotat' / клокотать, "fervilhar, borbulhar". Trocamos o termo por "está completa", sem trair totalmente o sentido, para ganhar a rima com "poeta" alguns versos depois. 
${ }^{167}$ Referência a Nuvem de calças. Na primeira versão do poema Sobre Isto a alusão a Nuvem de calças era explícita: “É uma segunda nuvem de calças que chega.” A passagem foi suprimida na versão definitiva. Cf. Jakobson, R. Russie, folie, poésie. Paris: Editions du Seuil, 1986, p. 125

${ }^{168}$ Em russo, verbo zvesdit'sa / звездиться criado a partir do substantivo zvezda / звезда, “estrela", outra imagem recorrente na poesia de Maiakóvski.

${ }^{169}$ Em russo, zatrubadurila / затрубадурила, verbo formado a partir do prefixo za- / за, que denota transformação, e do substantivo trubadur / трубадур, "trovador”. No original, havia uma rima com o verso sobre a lírica reforçando ainda mais a intimidade do sentido. Até o momento não conseguimos uma solução que satisfaça essa condição.

${ }^{170} \mathrm{O}$ monte Ararate é um maciço vulcânico e a mais alta montanha da Turquia, seu cume, sempre coberto de neve, atinge 5.137 metros. Segundo a Bíblia, nele estaria localizada a arca de Noé desde o fim do dilúvio.

171 Modificamos o terceiro emprego de skoro / скоро, "rapidamente, rápido", е empregamos "apressa o passo" para ganhar uma rima com o verso seguinte terminado em “espaço", apesar de não ser uma rima no original.

${ }^{172}$ Monte localizado no norte da Tanzânia, na fronteira com o Quênia, é o ponto mais alto da África com $5.895 \mathrm{~m}$. Nas línguas locais seu nome significa "montanha branca" ou "montanha brilhante" em função da neve eterna que recobre o seu topo.

${ }^{173}$ O verbo oblapit' / облапить, "abraçar com as patas” existe de fato em russo. Optamos pela criação de um neologismo em português, "patabraçar".

${ }^{174}$ Jogo com gruda / груда, "pilha, massa, monte", no sentido de grande quantidade, e grud' / груд', “peito”.

175 Verbo ej'iи / ежью criado a partir do substantivo ej / еж, "porco-espinho”. Na tradução “(eu) porcoespinho", optamos pelo mesmo processo de formação de palavras: 
verbalizamos o substantivo que denomina o animal. Outra possibilidade seria o verbo “ouriçar" existente em português. "Ouriço" pode designar uma espécie de porco-espinho, mas como não se trata de um neologismo em português, preferimos criar um.

176 Adjetivo krasnoflaguii / краснофлагий criado a partir do adjetivo krasnyi / красный, "vermelho", e do substantivo flag / флаг, "bandeira". Por questões de sonoridade, optamos pelo sinônimo "rubro", em vez de "vermelho", para formar o neologismo "bandeirrubro".

177 Ver nota 48.

${ }^{178}$ A mesma oficina reaparecerá em $O$ Percevejo e ressuscitará Prissípkin congelado por 50 anos.

${ }^{179}$ A imagem do químico do futuro também reaparecerá na peça $O$ Percevejo.

180 No original o verbo voskrechat' / воскрешать, "ressuscitar", é empregado no imperativo sem objeto direto. Deduz-se que se trata de um apelo de ressureição do próprio eu-lírico, mas Maiakóvski só emprega o pronome no acusativo meniá / меня, "me”, uma vez (ver nota 187). Das quatro traduções consultadas, apenas uma recupera esse traço do original. Optamos pelo emprego do pronome, para a evitar a ambiguidade inexistente no russo.

${ }^{181}$ No original o termo "sangue "aparece no grau aumentativo. Preferimos empregar a expressão "super" em vez de um sufixo. Aqui faz-se alusão à crença da época no poder da transfusão sanguínea como meio de rejuvenescimento e ressureição difundida pelo cientista e escritor de ficção científica bielorrusso Mikhail Bogdanov (1873-1928). O interesse de Maikóvski pela imortalidade do corpo foi nutrido pelas ideias do filósofo cristão russo Nikolai Fedorov (1829-1903), um dos principais representantes do Cosmismo, "um movimento filosófico e cultural de natureza antropocêntrica que surgiu na Rússia no início do século XX.” Cf. Jangfeldt, op. cit., pp. 253-4: 
trata-se da ressureição em carne e osso. Influenciado pelas reflexões do filósofo russo Nikolai Fiódorov sobre a ressureição dos mortos e pela teoria da relatividade de Einstein - que ele discutiu fervorosamente no verão de 1920 com Roman Jakobson -, Maiakóvski crê em um mundo futuro onde todos os mortos ressuscitarão fisicamente.

Fedorov "defendia o uso de métodos científicos que possibilitassem a prolongação da vida, imortalidade humana e a ressuscitação de pessoas mortas." Fonte: http://www.iep.utm.edu/fedorov/, acesso em 28 de dezembro de 2014.

Foi o pintor Vassili Tchekríguin

que lhe revelou as fantasiosas teorias do filósofo Fiódorov sobre a ressureição dos mortos”. O autor de Filossófia óbchchevo diela (Filosofia da obra comum), cujo segundo volume póstumo foi publicado naquele ano, tinha fascinação pela ideia de restituir a vida aos mortos. As suas doutrinas, imbuídas de uma fé utopista no futuro e nos progressos da ciência, deixaram marcas profundas na poesia e no teatro de Maiakóvski.

Cf. Chklóvski, V. O Maiakovskom (Sobre Maiakóvski), Moscou, 1940, p. 30 apud Ripellino, A. M., op.cit., p. 53. Na sua crença não havia nenhum viés religioso, “... para ele não há ressureição sem corpo, sem carne - a imortalidade não pode se dar no além; ela é inseparável da terra.” Cf. Jakobson, R. op.cit., p. 32.

Outra forte influência proveio da teoria da relatividade de A. Einstein (18791955), conforme a citação de Jangfeldt acima.

182 No original futliar / футляр. Referência ao conto Человек в Футляре (Нотет пит estojo), de A. Tchékov, traduzido para o português por B. Schnaiderman. Trata-se da história de um professor de grego antigo, Biélikov que vive obcecado por proteção e regras: usa galochas, guarda-chuva, não se envolve socialmente e só obedece às circulares. A personagem insere-se na linha do malenkii tchelovek / маленький челоиек, o homem insignificante, o pequeno funcionário. No final do conto de Tchékhov, o personagem Ivan Ivânitch diz:

E o fato de morarmos na cidade, sem espaço, numa atmosfera abafada, escrevermos papéis desnecessários, jogarmos uíste, não será isso um estojo também? E o passarmos a 
vida toda entre gente desocupada, entre rábulas, entre mulheres tolas e ociosas, falando e ouvindo banalidades, não será isso um estojo?

A figura do intelectual apartado da vida não agrada de forma alguma a Maiakóvski. Aliás, o "estojo" pode ser interpretado como a limitação da vida cotidiana contra a qual o poeta sempre levantou a voz. Cf. Tchékhov, A. P. A dama do cachorrinho e outros contos. Trad. de Boris Schnaiderman. São Paulo: Ed. 34, 2005, pp. 298.

${ }^{183}$ Mais uma referência a $O$ Percevejo: na cena final da peça, Prissípkin é exposto com o percevejo no jardim zoológico. Segundo Ripellino, “o jardim zoológico tem sua tradição no futurismo russo." O poema em prosa Zviérinietz (A coleção de bichos, 1909), um dos primeiros textos de Khlébnikov, é um exemplo. Cf. Ripellino, A. M., op.cit., p. 182.

${ }^{184}$ Trata-se da foto de Lília Brik no jardim zoológico de Berlim em 1922.

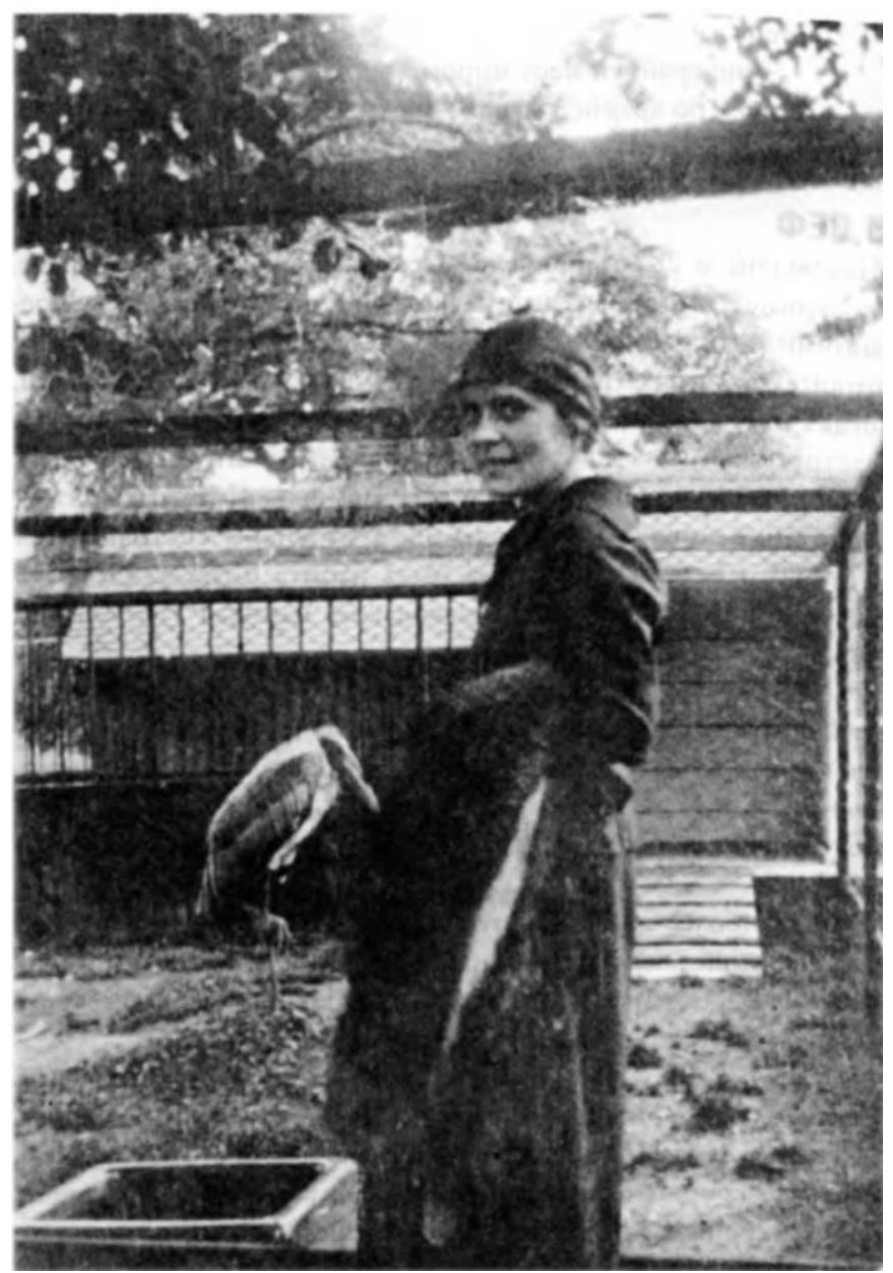

Fonte: http://coollib.com/b/166980/read, acesso em 27 de dezembro de 2014. 
${ }^{185}$ Em russo nedoliublennoе / недолюбленное, o que não viveu completamente o amor. O prefixo ne /не é de negação, do- / до- indica ação completa. A raiz vem do substantivo liubov' / любовь, “amor” e a terminação é de adjetivo. Até o momento não encontramos uma solução que contemplasse todas essas características em uma só palavra.

${ }^{186}$ Substantivo zvezdnost' $і$ / / звездностью, criado a partir do substantivo zvezda / звезда, "estrela" e do sufixo formador de substantivo nost' / ность. Embora seja mais frequente o uso do sufixo "-idão" na formação de substantivos de base adjetiva, decidimos empregá-lo sobre base substantiva pela ideia de coleção.

${ }^{187}$ Único emprego do complemento objeto direto do verbo voskrechat’ / воскрешать, "ressuscitar" no original. Ver nota 180.

${ }^{188}$ No original lejanka / лежанка, palavra de difícil tradução, superfície do grande forno tradicional das casas russas, onde as pessoas se deitavam nos dias mais frios. Optamos por "fogão", pois recupera parcialmente o sentido, é um objeto do cotidiano, e rima com "pão".

${ }^{189}$ A importância do termo é retomada no poema Liubov’ /Любовь , “Amor” (1926), que desenvolve a mesma ideia de Sobre Isto acerca do cotidiano, das mesquinharias e da hipocrisia da família tradicional. Maiakóvski usa diversas passagens de Sobre Isto neste poema bem mais curto.

$[\ldots]$

A nós

o pope não legitima com seu vozeiro.

É preciso

atar

a vida do homem e da mulher

com a palavra

que nos une:

"Companheiro".

(Tradução minha) 
PARTe II

SOBRE ISTO: UMA POÉTICA SÍNTESE

\section{I.1. Sobre Isto: a expressão do tema ${ }^{1}$}

O poema Sobre Isto, uma concatenação vertiginosa de situações, apresenta a seguinte arquitetura: uma espécie de prólogo ("Sobre o quê? - Sobre isto?"); o capítulo "Balada da Prisão de Reading", subdividido em 11 seções; o capítulo "A Noite de Natal", subdividido em 21 seções; e o que se poderia chamar de epílogo (“Petição a...") também subdividido em uma introdução e três seções. Segundo Khardjiev e Trenin ${ }^{2}$, análises dos manuscritos do poema permitem concluir que tal divisão não existia nos rascunhos e foi estabelecida somente na conclusão da primeira versão. Essa informação é importante na medida em que revela a concepção original da obra como algo uno.

No final de 1922, após a primeira temporada fora do país, Maiakóvski deveria apresentar duas conferências no Museu Politécnico. Durante a primeira, sobre Berlim, Lília Brik, que esteve com ele na viagem, fica revoltada com as impressões pouco originais do poeta. Ela interrompe a apresentação de modo contumaz com seus comentários e se recusa a ir à próxima conferência sobre Paris. A discussão atinge o ápice em 28 de dezembro de 1922, dia em que eles se separam ${ }^{3}$. Iniciam-se, assim, os dois meses de distanciamento em que o poeta comporá Sobre Isto.

A princípio, a incomunicabilidade deveria ser total, mas, aos poucos, eles começam a trocar bilhetes e cartas ${ }^{4}$. É interessante complementar a leitura do poema com esse material, pois há trechos idênticos que levam à comprovação da proximidade da vida e da arte. Aliás, como vimos, essa foi uma das críticas mais ferozes na recepção da obra: o caráter evidentemente autobiográfico, inaceitável na Rússia soviética. Jakobson, contrariando sua raiz formalista, afirma após a morte do poeta em 1930: "A crítica

\footnotetext{
${ }^{1}$ A divisão desta parte nas seções "a expressão do tema" e "a poética da expressão" tem caráter meramente didático. Sabe-se que para os cubofuturistas, Maiakóvski inclusive, conteúdo e forma são inseparáveis.

${ }^{2}$ Khardjiev, N e Trenine, V., op. cit., p. 233.

${ }^{3}$ Jangfeldt, B., op. cit., p. 233.

${ }^{4}$ Jangfeldt, B. (org.). L'amore è il cuore di tutte le cose. Vicenza: Neri Pozza, 2005.
} 
literária rebela-se contra as ligações imediatamente, diretas, entre a poesia e a biografia do poeta. Mas é absolutamente impossível concluir por uma necessária desvinculação entre a vida do artista e sua arte." ${ }^{5}$ A mesma opinião é compartilhada por Khardjiev e Trenin, segundo os quais a poesia de Maiakóvski é "fundamentalmente monológica e autobiográfica"6

De fato, a viagem empreendida pelo eu-lírico tem certamente uma reflexão autobiográfica, motivada por sua relação com Lília Brik, porém ela ultrapassa os limites individuais: suscita a reflexão acerca da missão do poeta e de como salvar o amor da miséria da vida cotidiana, expandindo o tema do âmbito individual e elevando à esfera universal.

A obra trava um diálogo com diversas outras, como tentamos apontar nas notas à tradução. Com relação à tradição herdada do século XIX, ele mesmo afirmou em "Como fazer versos?" que pretendia tirar os modelos do pedestal, afastar-se deles para melhor estudá-los e desmistificá-los como modelos obrigatórios ${ }^{7}$. Jakobson explica tal relação: “apesar de sua veemente repulsa aos 'generais clássicos', os futuristas russos estão visceralmente ligados à tradição literária da Rússia". ${ }^{8}$ Daí a expressiva referência aos clássicos russos e estrangeiros em Sobre Isto, conforme comentado anteriormente: Gógol, Dostoiévski, Lérmontov, Tchékhov, Púchkin, Oscar Wilde, Goethe.

A primeira relação se estabelece com Crime e Castigo, de Dostoiévski ${ }^{9}$, já no título (ver nota 1 à tradução): a expressão pro eto / про это (“sobre isto") é repetida incessantemente por Raskólnikov para designar seu crime: o assassinato da velha usurária. Segundo Jangfeldt ${ }^{10}$, Maiakóvski se identificava com a personagem: “a paixão devoradora por uma ideia, a obsessão de mudar o mundo por seus atos, a recusa em se

\footnotetext{
${ }^{5}$ Jakobson, R. A geração que esbanjou seus poetas. São Paulo: Cosac Naify, 2006, p. 39.

${ }^{6}$ Khardjiev, N e Trenine, V., op. cit., p. 232.

${ }^{7}$ O poema Jubileu expressa bem essa visão em relação aos clássicos: "Eu amo [Púchkin], / mas vivo. / não múmia. / Sem o verniz / dos florilégios-catacumba." O poema é a prova da reconciliação de Maiakóvski com o canônico Púchkin. In: Augusto e Haroldo de Campos e Boris Schnaiderman. Poesia Russa Moderna. São Paulo: Perspectiva, 2001, pp. 276.

8 Jakobson, R., op. cit., p. 28.

${ }^{9}$ No romance Doutor Jivago, de Pasternak, o personagem Iúri Andreevitch diz: “[...] Sempre gostei de Maiakóvski. É como uma continuação de Dostoievski. Ou melhor, sua poesia é um lirismo escrito por um dos personagens mais jovens e revoltados de Dostoievski, como Hipólito, Raskolnikov ou o herói de $O$ adolescente. Que devoradora força de talento! Como já foi dito, definitivo, intransigente e consistente! E o mais importante: com que ímpeto corajoso tudo isso foi jogado na cara da sociedade e além dela, para o espaço." Cf. Pasternak, B. Doutor Jivago. Trad. de Zoia Prestes. Rio de Janeiro, São Paulo: Record, 2002, p. 206.

10 Jangfeldt, B., op. cit., p. 249.
} 
deixar abater pela tristeza e pela rotina da vida cotidiana." O protagonista de Crime $e$ Castigo é inclusive citado no verso 1185 do poema:

\section{Como cuspes}

os sapatos na mão,

galgo os degraus.

A dor no coração não quer calar,

começa a selar elo a elo.

Foi assim

que ele,

o assassino Raskólnikov,

veio a campainha tocar.

Esse dado fornece uma das chaves de compreensão de todo o poema, segundo Mário Laranjeira ${ }^{11}$ :

Entre os indicadores formais da poesia, o título pode desempenhar um papel importante.

Ele funciona, frequentemente, como o tema de que o poema todo é o rema, ou a matriz de que o poema é a expansão. A obliquidade na relação entre ambos pode ser uma das chaves da significância do poema.

Podemos interpretar a expressão "sobre isto" sob duas perspectivas. O tema não pode ser nomeado na sociedade em que vive Maiakóvski, pois dedicar versos a assuntos considerados individualistas é considerado uma traição aos ideais do coletivo, daí o uso de uma expressão indefinida para referir-se a ele indiretamente. Do ponto de vista da relação com o romance de Dostoiévski, e já adiantando a relação com o poema de Oscar Wilde que dá título à seção seguinte, há uma alusão a um crime, neste caso, o

${ }^{11}$ Laranjeira, M., op. cit., p. 58. 
aniquilamento da pessoa amada pelo ciúme e pelo desgaste da rotina. Em suma, fala-se da morte do próprio amor.

O prólogo "Sobre o quê - Sobre isto?" é a súmula do que o poeta quer nos apresentar. Análises dos manuscritos revelaram que o prólogo foi a última parte escrita $o$ que nos leva à conclusão de que, de fato, o poeta tinha a intenção de, com ele, apresentar a obra ao leitor. ${ }^{12}$ Sem nomear o tema, ele o define: é pessoal, banal, cantado inúmeras vezes, com linguagem desgastada, mas nunca se consome. O tema precisa ser tratado de modo belo e verdadeiro e, apesar de desgastado, está longe de ser um tema simples. A dificuldade está justamente em seu caráter repetitivo, tantas vezes abordado. Como conferir-lhe tratamento novo condizente com a nova arte e a nova sociedade? Eis o desafio de Maiakóvski. O tema renova-se à medida que a sociedade se revoluciona. Não cabe mais o amor burguês, possessivo, impregnado de ciúme. A nova sociedade exige uma nova abordagem do amor. A nova arte exige uma nova poesia, afinal, como proclamava o futurismo russo segundo o manifesto A palavra como tal (1913), "é a nova forma verbal que cria o novo conteúdo. ${ }^{13}$

Após a sugestão do tema no prólogo, tem início a narrativa. O eu-lírico está em seu apartamento comparado a uma cela de prisão. A associação mais direta com o poema de Wilde (ver nota 22 à tradução) baseia-se nas condições em que Maiakósvki escreveu Sobre Isto - isolado na Passagem Lubiánski -, mas Jakobson chama a atenção para a relação mais profunda entre a morte do condenado do poema de Wilde e a execução do poeta na seção “A última morte". ${ }^{14}$

Ansioso, ele tortura-se ao lado do telefone: quer ouvir a voz da amada, mas não sabe se será atendido. Aliás, os objetos cotidianos estão presentes no poema, muitos transladados da vida real. Segundo Khardjiev"15, "na poesia de Maiakóvski, o mundo é orquestrado. Maiakóvski personifica os objetos inanimados e as noções abstratas e faz deles participantes de uma sinfonia grandiosa." O telefone e o globo, a mala, a cama com barras de ferro e o cobertor, as roupas, todos esses elementos entram na cena desértica do

\footnotetext{
${ }^{12}$ Khardjiev, N., Trenine, V. "Le travail de Maïakovski sur le poème De ceci". In : Khardjiev, N., Trenine, V., op. cit., p. 233.

${ }^{13}$ Manifesto de Khlébnikov e Krutchonikh. Cf. Livichits, B. L'archer à un oeil et demi. Lausanne : L'Age d’Homme, 1986, prefácio de Valentine e J. C. Macardé, p. 13.

${ }^{14}$ Jakobson, R. "Maïakovski. Les derniers poèmes lyriques". In: Russie, folie, poésie. Paris : Editions du Seuil, p. 148.

${ }^{15}$ Khardjiev, N. "Les leitmotivev sémantiques". In: Khardjiev, N., Trenine, V., op. cit., p. 278.
} 
poema, mas não cumprem nenhuma de suas funções, tampouco caracterizam o espaço nu, minimalista como pregavam os princípios ideológicos e artísticos da época.

Ela recusa-se a atendê-lo o que desencadeia o ciúme e sua transformação em um urso que navega no rio de suas próprias lágrimas. Navegando, vê seu duplo, também desprezado pela amada, sobre uma ponte no rio Nevá: “o homem de sete anos antes", uma referência ao seu poema $O$ Homem. Seu duplo suplica que o liberte das linhas dos versos que o prendem à ponte, pergunta-lhe se cedeu à felicidade burguesa da vida em família, ameaça-o e o condena a vagar solitário enquanto não for libertado.

Na segunda parte, "A Noite de Natal”, o eu lírico vai de São Petersburgo para Moscou. Ele atravessa ambientes pequeno-burgueses, procurando desesperadamente alguém que o ajude a libertar o homem da ponte - ele mesmo. A busca revela-se um esforço inútil, pois nem mesmo sua família o apoia na empreitada. Ele está sempre só. É noite de natal, símbolo dos rituais domésticos burgueses. Correndo, braços abarrotados de presentes de natal, o eu-lírico constata que nada mudou com a revolução e que ele mesmo aburguesou-se como os outros.

Nem a própria amada responde ao seu apelo, absorta na sua vida social e ensurdecida pelo one-step. Mais uma vez o dado biográfico é comprovado: Maiakóvski tinha conhecimento da vida social intensa de Lília durante a separação, como informa Jagfeldt: "enquanto ele ronda as janelas de Lili, Maiakóvski pode constatar que vida ela leva em sua ausência, sempre com muitos convidados, música, dança - o one-step e o two-step estavam a todo o vapor." 16

O herói viaja a vários países, mas em todos os lugares o cenário é o mesmo, todos estão preocupados com ninharias e ninguém se dispõe a ajudar o homem na ponte. De volta a Moscou, novamente no natal, ele teme que tudo recomece. Refugia-se, então, no campanário da torre de Ivan, o Grande, em cuja base se amontoam os burgueses perseguidores, desafiando-o para o duelo. Ele é executado e seus farrapos transformamse em bandeira vermelha sobre o Kremlin. Mas tudo não passou de um sonho: o poetatrovador navega na Ursa Maior rumo ao futuro na arca-concha.

O epílogo é uma petição dirigida a um químico do século $30^{17}$. O eu-lírico pedelhe que o ressuscite para que viva até o fim e possa amar com toda a sua capacidade. Os

\footnotetext{
${ }^{16}$ Jangfeldt, B., op. cit., p. 238.

${ }^{17}$ O futuro é um tema retomado nas peças O Percevejo (1928) e Os Banhos (1929).
} 
subcapítulos têm como nomes três palavras-chaves do Novo Testamento bíblico: fé, esperança e amor, e seu tema é a ressureição.

Embora, no âmbito pessoal, Maiakóvski nutrisse um ciúme excessivo de Lília, o que ele defende aqui é o amor universal, desapegado do sentimento de propriedade prérevolucionário e avesso aos ideais socialistas. Na carta-diário que escreveu durante o período de isolamento ele diz:

Não é a mim que você ama - o seu amor é universal. Nele tenho o meu lugar [...], mas o dia em que não o tiver mais, vão me retirar como uma pedra enquanto o seu amor continuará a irrigar o universo. Estou errado? Não, para você isto está bom, e eu gostaria, eu mesmo, de poder amar assim. [...]

Não há famílias ideias. Todas as famílias são fragmentadas. Tudo o que pode existir é um amor ideal. Mas o amor não se cria com base em "você deve" ou "você não deve", mas em uma luta livre com o mundo inteiro. ${ }^{18}$

Tão elucidador quanto o título é esta conclusão se nos basearmos na afirmação do próprio poeta para quem "um dos momentos sérios do poema, momento particularmente tendencioso e declamatório, é o final. Neste final, geralmente se colocam as linhas mais realizadas de um poema" 19 . Hiperbólico, o poema conclui-se com um poeta apartado do mundo, sua voz na imensidão, dirigindo um apelo ao futuro. De grande lirismo, a seção “O Amor", célebre pela adaptação musical de Caetano Veloso, encerra o poema como uma espécie de resumo, em que Maiakóvski lança ao mundo sua concepção do amor condizente com a nova sociedade, "o amor que não é mais eros, mas ágape, quando o individualismo da família será substituído por uma comunidade de todos os homens" ${ }^{20}$, uma sociedade esteada não mais na família burguesa, mas na comunhão entre as pessoas. O Comunismo que ele deseja só pode estar no futuro e nada tem a ver com a experiência incompleta do presente.

\footnotetext{
${ }^{18}$ Apud Jangfeldt, B., op. cit., p. 240. Grifos meus.

${ }^{19}$ Maiakóvski, V. "Como fazer versos". In: Schnaiderman, B. A Poética de Maiakósvski. São Paulo: Perspectiva, 1971, p. 200.

${ }^{20}$ Jangfeldt, B., op. cit., pp. 253-4.
} 
Alguns críticos ressaltam a independência de Maiakóvski em relação ao movimento cubofuturista ${ }^{21}$. Com efeito, sua poética é marcada por uma singularidade que, por vezes, o afasta parcialmente do programa do movimento, mas também não se pode esquecer que ele era extremamente variegado, conforme aponta Livchits ${ }^{22}$. O lirismo, quase inexistente na poética cubofuturista, explode em Maiakóvski, aproximando, em muitos momentos, como vimos, biografia e poesia. A esse respeito, Lília Brik comentou que "os temas de seus versos sempre foram suas próprias emoções" e isto se refere a "todos os seus versos, até mesmo os textos de propaganda."23

A despeito da defesa da coletividade da obra e do anonimato sob a palavra "nós", postulados no manifesto Bofetada no gosto público ${ }^{24}$, o lirismo do poeta recrudesce ao longo dos anos e, "de seus primeiros poemas programáticos evolui gradativamente para a poesia do Ich-Dichtung ('ego-lírico') e para as formas extensas." 25

Em Russie, folie, poésie, Jakobson aponta para o caráter cíclico dos poemas de amor (líricos) e os lírico-épicos (sobre acontecimentos universais) ${ }^{26}$. O primeiro ciclo lírico compreende A Flauta-vértebra (1915), Nuvem de calças (1916), A todos (1916), Lílitchka (em lugar de uma carta) (1916) e Don Juan (1916) - poema destruído pelo próprio poeta. A Guerra e o Mundo (1916) interrompe o fluxo e aborda as lutas do seu tempo.

Novamente instala-se o lirismo com O Homem (1916), de 1916 a outubro de 1917. Em 1919, corroborando a alternância "poemas do coração" e "poemas da razão", ele começa a compor 150.000.000. Em 1920 concebe um novo poema político e social, mais tarde intitulado A Quinta Internacional.

\footnotetext{
${ }^{21}$ Tal fato se deve ao processo de absorção de Maiakóvski pelo regime soviético como instrumento de propaganda, conforme exposto anteriormente. Cf Ripellino, A. M., op. cit., p. 11.

${ }^{22}$ Segundo ele, faltava uma base filosófica comum, o que impedia o grupo de formar uma escola literária. Livchits, B. L'archer à un Eil et demi. Lausanne : L'Age d'Homme, 1971, p.144.

${ }^{23}$ Jakobson, R. op. cit., p.143.

${ }^{24}$ Além de ter sido um dos redatores do manifesto, Maiakóvski defendeu em outros momentos a ideia da obra coletiva. Publicou anonimamente o poema 150.000 .000 e sugeriu que outros o completassem e escreveu uma "antibiografia" imprecisa e sucinta.

${ }^{25}$ Pomorska, K. Formalismo e Futurismo. A Teoria Formalista Russa e seu Ambiente Poético. São Paulo: Perspectiva, 2010, p. 148.

${ }^{26}$ Jakobson, R., op. cit., p. 123.
} 
Mais uma vez o lírico o chama e, de novembro de 1921 a fevereiro de 1922, compõe seu "poema idílico"27 (como o denomina Jakobson), Amo. O trágico Sobre Isto vem no inverno do mesmo ano. Jakobson salienta que esses três ciclos de poemas de amor estão intimamente ligados. Tal ligação é reforçada pelas constantes referências de um ciclo a outro, como tentamos explicitar ao longo do trabalho.

Vladímir Ilitch Lênin, concluído em outubro de 1924, interrompe mais uma vez o ciclo lírico, que é retomado em Jubileu (1924), poema em homenagem a Púchkin em que ele confessa para o poeta estar "livre do amor". Na primavera de 1926 ele projeta o segundo poema sobre a revolução Tudo bem. Nos poemas Carta de Paris ao Camarada Kostrov sobre a Essência do Amor e Carta a Tatiana Iákovleva, ambos de 1928, reavivase o lirismo que se encerra somente nos fragmentos que deixou ao morrer.

Não se deve, contudo, daí depreender uma sistematização petrificada da obra de Maiakóvski. Os ciclos referem-se a um recrudescimento de um ou outro viés, o que não significa que um anulasse o outro. Jakobson fala em "quadro indivisível" em que duas forças contrárias - "o sufocamento da ressureição do lirismo"28 - estão em constante tensão na sua obra. A despeito de todos os exemplos apontados acima, Maiakóvski afirma na exposição de 20 anos do seu trabalho, em 25 de março de 1930: "por que eu deveria escrever sobre o amor de Mania e Pétia em vez de me considerar como uma parte deste organismo de estado que constrói a vida ${ }^{29}$ A menos de um mês de seu suicídio, o embate entre o pessoal e o social chegara ao limite.

Jakobson concentra a base da obra de Maiakóvski na luta contra a vida cotidiana e o pensamento pequeno-burguês. As questões fundamentais para o poeta são a desunião, a contradição entre a construção técnica e a poesia e "o lugar do poeta num regime operário". ${ }^{30}$ A escolha das imagens guiava-se pela expressividade e, não raro, eram transformadas e estilizadas com o intuito de caricaturar. Uma leitura atenta da obra de Maiakósvski permite a apreensão da recorrência de certas imagens e temas, o que Khardjev chamou de "imagens obsessoras"31. Em seu ensaio com Trenin, o crítico

\footnotetext{
27 Idem, p. 124.

${ }^{28}$ Idem, p. 139.

${ }^{29}$ Idem, ibidem.

${ }^{30}$ Jakobson, R. A geração que esbanjou seus poetas. São Paulo: Cosac Naify, 2006, p. 21.

${ }^{31}$ Khardjiev, N. "Les images obsédantes". In : Khardjiev, N., Trenine, V., op. cit., p. 276.
} 
afirmou ainda que "as condições do verso livre oral deram a Maiakóvski a possibilidade de desenvolver com uma força extraordinária um sistema de novas imagens poéticas"32

Uma delas é o conflito entre o amor e a vida cotidiana, tema central de Sobre Isto. Jakobson também percebeu a insistência do tema da inércia do dia-a-dia, o "inimigo primordial do poeta" ${ }^{33}$, e do tema "irracional mais decisivo": o amor esmagado pelo byt. ${ }^{34}$ Ele afirma que somente nesta obra "revela-se claramente a luta desesperada do poeta com a vida cotidiana" ${ }^{35}$ : o poeta insurge-se contra ela e a consequência é a sua execução.

$\mathrm{O}$ arquinimigo do poeta sempre foi o filistinismo. O maior temor de Maiakóvski era a imutabilidade e a inércia da vida: "o fantasma de uma ordem mundial imutável - da vida cotidiana universal acomodada em apartamentos - sufoca o poeta."36 Maiakóvski odiava o comodismo e seus versos serão sempre uma arma apontada para a busca do conforto.

Como Nuvem de calças, Sobre Isto critica o amor e a sociedade do seu tempo. As contínuas referências a $O$ Homem - poema pré-revolucionário - são a prova de que para o poeta, nada mudou apesar de duas revoluções. Aliás, as imagens do poema $O$ Homem, o mais desesperado de seus longos poemas da primeira fase, reverberam por toda a poesia de Maiakóvski. O Homem e Sobre Isto, são, para Jakobson, "um canto lúgubre da vida cotidiana que triunfa sobre o poeta" ${ }^{37}$. Jakobson diz que os versos de Sobre Isto são uma "repetição do passado" 38 intensificada e levada à perfeição. Mas será a última vez que o poeta dedicará um longo poema ao amor: “o caminho do poema elegíaco foi esgotado por Maiakóvski em 1923"39. O amor reaparece no último ciclo lírico, como apontamos, mas com outra abordagem.

A ligação com a revolução é primordial, conforme salienta Jakobson. Entretanto, mais uma vez sua disposição para o auto sacrifício mostra-se inútil. Ele é humilhado e destroçado pelo velho sistema burguês e pela vida cotidiana que o circunda, e sobrevive apenas nos farrapos da bandeira vermelha, esperando a revolução que ainda virá.

\footnotetext{
${ }^{32}$ Khardjiev, N. e Trenine, V., op. cit., p. 232

33 Jakobson, R., op. cit., p. 16.

${ }^{34}$ Idem, pp. 23-4.

${ }^{35}$ Idem, p. 17.

${ }^{36}$ Idem, p. 19.

${ }^{37}$ Idem, p. 38.

${ }^{38}$ Idem, p. 43.

${ }^{39}$ Idem, ibidem.
} 
Jakobson afirma que "o poeta é a vítima expiatória, sacrificada em nome da verdadeira e futura ressureição universal" 40 .

Outro tema fundamental abordado em Sobre Isto é o suicídio. Ele aparece pela primeira vez em 1913 em Vladímir Maikóvski, uma tragédia e é retomado em O Homem. Avesso ao otimismo revolucionário, o motivo é tão recorrente na obra de Maiakóvski que Jakobson $^{41}$ vê nele o prenúncio da morte do poeta em 1930. O suicídio representa a epítome de seu embate com o tempo. Em seu desespero para acelerar a chegada do futuro idílico, o poeta está condenado ao "exilio do presente" 42 . O tema do suicídio torna-se mais obsessivo à medida que o tempo passa, pois adquire-se a consciência do esmagamento inexorável promovido pelo byt.

A função do poeta para Maiakóvski estaria, então, ligada à crença da superação do tempo, outro tema contumaz na poesia maiakovskiana, talvez o mais fundamental deles $^{43}$. Sua obsessão pelo futuro atravessa toda a obra, pois o poeta deveria adiantar-se, projetar-se no futuro.

No artigo "Mayakovsky and His Time Imagery"44 ("Maiakóvski e seu Imaginário do Tempo"), Thomson afirma:

Maiakóvski raramente fala sobre o tempo de modo abstrato; ele quase sempre distingue precisamente entre o tempo passado e o tempo futuro. Pode-se até dizer que ele faz uma distinção moral entre os dois: o tempo passado é invariavelmente ruim, enquanto o tempo futuro é quase sempre bom.

Assim, ele proclama e apressa o porvir e anseia se projetar num futuro utópico. A necessidade particular de participar, mudar os contornos de algo aparentemente imutável, leva-o à outra imagem: o poeta como salvador ou redentor. ${ }^{45}$ Nessa jornada do passado ao futuro é frequente que ele se coloque como uma espécie de Noé ou Cristo, conduzindo o mundo, exatamente como se vê em Sobre Isto.

\footnotetext{
${ }^{40}$ Idem, p. 20.

${ }^{41}$ Idem, p. 30.

${ }^{42}$ Idem, p. 37.

${ }^{43}$ Idem, p. 35.

${ }^{44}$ Thomson R.D.B., "Mayakovsky and His Time Imagery”. In: op. cit., p. 182.

${ }^{45}$ Idem, p. 186.
} 
A quebra desse paradigma "passado - ruim versus futuro - bom”, virá justamente com a NEP, em 1921. Thomson ${ }^{46}$ observa que, até então, ele pudera coadunar sua mitologia temporal com o marxismo, mas a política implementada por Lênin defendia um recuo tático e conflitava com a sua visão teleológica. Em Sobre Isto a angústia da restauração do passado assumirá proporções agônicas. De fato, Jakobson diz que "o poema é o lamento contínuo mais desesperado em muitos séculos."47

Para Thomson, Sobre Isto é uma das grandes obras do período e talvez uma das mais complexas de Maiakósvki em que a linha de pensamento salta para frente e para trás, no espaço e no tempo ${ }^{48}$. Esse foi um dos desafios da tradução: os tempos e aspectos verbais alternam-se e confundem-se. Em certos momentos não obedecemos ao original ${ }^{49}$, mas procuramos sempre manter a fluidez e o dinamismo temporais do poema, em que passado, presente e futuro perdem a precisão das fronteiras, como ilustram os excertos a seguir:

Lenta, a cozinheira levantou,

vai,

escarrando.

É como uma maçã enrugada.

Os pensamentos encrespam sua fronte.

- Quem?

Vladímir Vladímitch?!

Ah tá!-

Foi, arrastando o chinelo.

Chega.

(vv. 220-229)

Na passagem selecionada há uma sequência de ações da cozinheira no presente e no gerúndio, respectivamente: idiot / идёт, "vai" е kharkaia / харкая, “escarrando". А série é desencadeada por um verbo perfectivo no passado, podnialas' / поднялась,

\footnotetext{
${ }^{46}$ Idem, p. 192.

47 Jakobson, R. op. cit., p. 41.

${ }^{48}$ Thomson, op. cit., p. 194.

${ }^{49}$ Ver nota à tradução de número 9.
} 
"levantou-se"; e quebrada pelo verbo perfectivo no passado pochla / пошла, "foi". Finalmente é retomada pelo presente idiot / идёт, "vai".

E no meio,

assim,

como nunca sonhado,

um tanto orgulhosa de sua roupa branca nova,

pelo universo

estendeu-se a Miasnítskaia,

miniatura de marfim.

Clareza.

Tortura da transparente clareza.

Na Miasnítskaia,

detalhe do traçado hábil,

o cabo

fininho -

mas é apenas um filete!

E tudo

está por um fio.

(vv. 270-285)

Nestes versos, percebemos uma interpolação dos tempos verbais na narrativa. Por um lado, o cenário da Miasnítskaia é descrito com o verbo no aspecto perfectivo liétch' / лечь, conjugado no passado; na tradução, pretérito perfeito do indicativo. Por outro, o fio do telefone, que percorre a avenida e dentro do qual está a sorte do eu-lírico, está associado a verbos no presente: byt' / быть, "ser", que não é empregado no presente em russo e derjat'sia / держаться, "manter-se, segurar-se", traduzido como "está" na expressão "estar por um fio" que recupera o caráter de uma expressão popular.

Ora entrelaça as mãos,

como se orasse.

Ora as agita,

como num comício a discursar.

A neve é algodão.

O rapazinho caminhava pelo algodão. 
Os verbos destacados acima também apresentam uma quebra na lógica temporal. As ações do jovem Komsomol são inicialmente expressas no presente slojit / сложит, "entrelaça", machet / машет, "agita", para, em seguida, serem substituídas por um verbo imperfectivo no passado, chiol / шёл, aqui traduzido por "caminhava".

O tempo é trabalhado de forma complexa em Sobre Isto, em que a amargura da situação presente estimula a fuga para o passado. Mas a solidariedade o traz novamente para o presente em busca de ajuda e, quando sua empreitada falha, a esperança o impele para um futuro longínquo. Sobre Isto é uma viagem pelos meandros do tempo, como a “Teoria da Relatividade" de Einstein que tanto fascinava Maiakóvski.

Vimos nessa seção o contexto da criação do poema, sua macroestrutura e comentamos brevemente a riqueza de imagens e referências. Percebe-se assim a sua importância no conjunto da obra de Maiakóvski no tocante aos temas que trabalha. Na próxima seção, discorreremos mais detidamente acerca dos elementos formais que compõem Sobre Isto.

\section{2. Sobre Isto: a poética da expressão}

O poema Sobre Isto é considerado por muitos especialistas e pelo próprio poeta como um de seus trabalhos mais importantes: "É para mim, eu penso, e para todos os outros, minha obra mais importante e a mais cuidadosamente trabalhada" ${ }^{" 50}$. Assim, pretendemos demonstrar por que ele constitui uma síntese da poética de Maiakóvski. Com tal intuito, nesta seção demonstraremos que todos os elementos formais de composição característicos do poeta estão nele presentes, à luz de exemplos extraídos de nossa tradução e com o embasamento teórico de Brik, Jakobson, Khardjiev, Trenin, Pomorska, do próprio Maiakóvski e outros.

\footnotetext{
${ }^{50}$ Khardjiev, N., Trenine, V., op. cit., p. 234.
} 
Conforme exposto anteriormente, não há como dissociar Maiakóvski do movimento a que pertenceu, mas também seria muito redutor não considerar seu estilo pessoal. Com os cubofuturistas ele compartilhou:

a criatividade programática da palavra poética, a fixação na renovação da linguagem, mas para ele tudo isso deveria ter um objetivo além da palavra em si mesma. [...] Maiakóvski aplicou suas experiências linguísticas ao contexto social. Deste modo a temática revolucionária encontrou a forte expressão em sua poesia e mesmo os seus motivos mais pessoais são elevados a uma escala social e às vezes universal. ${ }^{51}$

A linguagem poética de Maiakóvski é extremamente rica e solidamente apoiada na sonoridade dos versos, sobretudo na rima. Assim, propusemos na "Parte I" uma tradução poética que se esforçou para recriar em língua portuguesa a riqueza e a complexidade sonoras do original russo, ultrapassando a mera exposição do conteúdo narrativo do poema.

Maiakóvski ampliou a função da poesia e do poeta. Para ele era função do poeta criar as regras da nova poética que se impõem pela vida e pelas exigências sociais. Seu principal interesse era, então, a "oficina poética": o poeta-operário tinha na poesia seu ofício, especializado, complexo, mas passível de sistematização. Conforme afirmado na anteriormente, Jakobson aponta a relação entre a "construção técnica e a poesia" e o "lugar do poeta num regime operário" como questões fundamentais em sua poética. ${ }^{52}$

Em poesia o aspecto sonoro é particularmente importante na produção do sentido, isto é ainda mais evidente em Maiakóvski. Os cubofuturistas aproximavam-se dos formalistas na medida em que tentavam associar forma e conteúdo, e mesmo as transgressões de poetas que realizaram experiências ousadas com a língua, como Khlébnikov, respeitavam essa relação. Segundo Pomorska, “o ponto principal da estética futurista foi a teoria da palavra em seu aspecto sonoro, como o único material da poesia. A base desta teoria foi o conceito cubista de artes visuais"53. Ao contrário dos simbolistas, mais preocupados em renovar a linguagem visando à criação de novos símbolos, os cubofuturistas buscavam a "palavra pura". Livchits, outro cubofuturista, revela em seu

\footnotetext{
${ }^{51}$ Pomorska, op. cit., pp. 148-9.

52 Jakobson, R., op. cit., p. 21.

${ }^{53}$ Pomorska, op. cit., p. 102.
} 
livro L'archer à un oeil et demi, que ele mesmo partira de uma posição teórica diametralmente oposta para a "afirmação da unidade da forma e do conteúdo, como a suprema realidade que se revela na arte" 54 e que aprendeu a dar um "novo valor à palavra reforçada pelo som"55.

Falar em som e sentido remete-nos a outro contemporâneo de Maiakóvski, Jakobson, formalista que dedicou especial atenção ao assunto. Ele afirmou que o aspecto fônico da palavra dissolve-se em unidades distintivas ou fonemas. O fonema em si, que por sua vez também se decompõe em propriedades distintivas, é um elemento desprovido de significado próprio ${ }^{56}$. Com efeito, não há um sentido em si, “o sentido sempre faz parte de qualquer coisa que serve de signo; por exemplo, nós interpretamos o sentido de um signo linguístico, o sentido de uma palavra."

Ora, o liame entre a série de fonemas e o sentido é necessário, mas a única ligação essencial entre os dois aspectos é a associação que repousa em uma relação de contiguidade, ou seja, externa, enquanto a associação baseada na semelhança, isto é, numa relação interna, é apenas facultativa. Segundo ele, esse vazio tende a ser completado: "a intimidade entre som e sentido da palavra enseja os falantes a completarem a relação externa por uma interna, a contiguidade por uma semelhança, pelo rudimento de um caráter imagético"58. Holquist ${ }^{59}$, no ensaio "Roman Jakobson and philology" ("Roman Jakobson e filologia"), esclarece que os sons selecionados por uma língua particular, como determinadas vogais e consoantes não são selecionados arbitrariamente, mas de forma sistemática. Jakobson crê ainda que as “oposições fônicas são até capazes de evocar relações com sensações musicais, cromáticas, olfativas, táteis, etc" ${ }^{\circ 0}$.

Para Jakobson, é na linguagem poética, na qual o signo assume valor autônomo, que o simbolismo fonético alcança sua atualização e cria uma espécie de acompanhamento do significado. ${ }^{61}$ Ora, nesse poema percebemos claramente que os recursos sonoros e rítmicos pretendem reforçar a temática tratada. Todo o poema é

\footnotetext{
${ }^{54}$ Livchits, B., op. cit., p. 62.

${ }^{55}$ Idem, ibidem.

56 Jakobson, R. Six leçons sur le son et le sens. Paris : Les Éditions de Nuit, 1976, p. 115.

${ }^{57}$ Idem, p. 117.

${ }^{58}$ Idem, ibidem.

${ }^{59}$ Holquist, M. "Roman Jakobson and philology". In: Renfrew, A., Tihanov, G. (org.). Critical Theory in Russia and the West. London, New York: Routledge, 2010, p. 87.

${ }^{60}$ Jakobson, R., op. cit., p. 117.

${ }^{61}$ Idem, p. 119.
} 
"costurado" de modo a reiterar a luta do eu-lírico contra o pensamento individualista e por um amor universal.

Em Maiakóvski tal associação é potencializada pela rima, recurso que ele preconiza, não pelo simples efeito estético, mas pela relação íntima que logra estabelecer com o sentido e em prol do ritmo, aspecto que abordaremos em seguida. Seu ensaio “Como fazer versos" elucida muitos aspectos da sua poética. No tocante à rima, diz que ela obriga "a voltar à linha anterior e lembrá-la, obriga todas as linhas, que materializam o mesmo pensamento a se manterem unidas." 62

Para se ter uma ideia do quão importante era o trabalho de Maiakóvski com as rimas, Khardjiev e Trenin ${ }^{63}$ notaram nos manuscritos ${ }^{64}$ de Sobre Isto as reservas poéticas, mencionadas pelo poeta em "Como fazer versos". Tais reservas consistem em pares de rimas que antecederam a composição do poema, tais como kak te - kagtei / как те кагтей ${ }^{65}$, “como aqueles - unhas", stepi - tustepe $e^{66} /$ степи - тустепе, “estepes - twostep", rimas possíveis somente "porque o verso dele se conforma à realidade fonética"67. Detentora de enorme força semântica, a rima é a "alavanca semântica original do verso"68. E, como vimos, "é fundamental a correlação e interdependência dialéticas dos elementos semânticos e dos elementos fonéticos na construção dos versos." 69

Acerca da rima em Maiakóvski, Khardjiev comenta que, a exemplo de todos os outros elementos do verso, ela faz parte de uma "construção literária complexa, na qual os aspectos semânticos e fonéticos da palavra encontram-se em uma correlação e uma interação mútuas indissolúveis". ${ }^{70}$ Peterson afirma que os longos jogos rítmicos de Maiakóvski criam ressonâncias irônicas e funcionam como uma "materialização" do "enredo" do poema. ${ }^{71}$

\footnotetext{
${ }^{62}$ Maiakóvski, V. “Como fazer versos”. In: Schnaiderman, B. A poética de Maiakóvski. São Paulo: Perspectiva, 1971, p. 191.

${ }^{63}$ Khardjiev, N., Trenine, V., op. cit., p. 235.

${ }^{64} \mathrm{Um}$ dos raros que se conservaram, visto que o poeta costumava destruir seus rascunhos quando a obra estava pronta.

${ }^{65} \mathrm{Na}$ tradução recuperamos a relação entre os termos com "ursamente" ("como aqueles ursos") e com a expressão "unhas e dentes" (vv. 375 e 379).

${ }^{66}$ Graças à semelhança fonética entre os termos nas duas línguas de trabalho, a tradução foi simples. (ver vv. 1265-1266).

${ }^{67}$ Idem, p. 236.

${ }^{68}$ Idem, ibidem.

${ }^{69}$ Idem , p. 243.

${ }^{70}$ Khardjev, N. "L'évolution de la rime de Maïakovski. In : Khardjiev, N., Trenine, V., op. cit., p. 268.

${ }^{71}$ Peterson, D. E. "Mayakovsky and Whitman: The Icon and the Mosaic" "Maiakóvski e Whitman: o Ícone e o Mosaico"). In: Slavic Review, Vol. 28, № 3 (Sep., 1969), pp. 416-425 Published by: Association for Slavic, East European, and Eurasian Studies Stable URL: http://www.jstor.org/stable/2494019, p. 422.
} 
Eis um dos maiores desafios que enfrentamos na tradução de Sobre Isto. Não se pode exagerar na distribuição de rimas para garantir o ritmo e a sonoridade como meros ornamentos, é preciso fazer o máximo esforço para recuperar as mesmas associações de sentido estabelecidas no original. Em alguns casos conseguimos, em outros, a rima foi recuperada somente em outros versos do poema, entre outros termos, por compensação.

Tal dificuldade leva o tradutor a um trabalho quase obsessivo em que processa mentalmente rimas em tempo integral em busca da solução mais satisfatória para determinados versos. O que nos faz lembrar de uma declaração de Maiakóvski: "uma rima que se está caçando, mas ainda não se conseguiu agarrar pelo rabo nos envenena a existência: você conversa sem compreender, come sem distinguir, e perde o som, quase vendo a rima que voa diante dos seus olhos"72. Entendemos na prática o que o poeta quis dizer.

É necessário tecer um comentário acerca das diferentes categorias de rima em Maiakóvski, pois não se trata forçosamente da consonância final, mas em qualquer ponto do verso, com várias possibilidades de combinação. De todo modo, as rimas não deveriam ser transparentes, mas sim espantar e deter a atenção, "costurando" as linhas. Muitas vezes nem constituem uma consonância absoluta, mas uma semelhança. Aliada à mobilidade tônica, ela constituía o principal procedimento do poeta. Ora ele rimava uma palavra acentuada com parte de outra não acentuada, ora a própria declamação permitia tal deslocamento. Brik afirma que "cada sílaba pode ser acentuada ou não, tudo depende do impulso rítmico". ${ }^{73}$ De acordo com Pomorska: "Sendo sensível a todos os fatores do ritmo, Maiakóvski utilizou os valores fonológicos da acentuação russa mais intensamente do que qualquer outro poeta." 74

Khardjev traça o percurso do desenvolvimento da rima na obra de Maiakóvski e comenta que, nos seus primeiros versos, as rimas são muito simples do ponto de vista formal $^{75}$ (rima entre termos de mesma classe gramatical e mesmo caso, por exemplo). No entanto, mesmo assim, tais rimas são muitos eficazes, pois evidenciam as palavras mais importantes para o tema do poema e funcionam como "palavras-chaves" de toda a sua organização semântica.

\footnotetext{
${ }^{72}$ Maiakóvski, V., op. cit., p. 178.

${ }^{73}$ Brik, O. "Ritmo e Sintaxe". In: Teoria da literatura. Formalistas russos. Porto Alegre, Globo, 1973, p. 133.

${ }^{74}$ Pomorska, K., op. cit.., p. 153.

${ }^{75}$ Khardjiev, N., op. cit., p. 269.
} 
Posteriormente, com o desenvolvimento da técnica de Maiakóvski, sua poética voltou-se para a "pesquisa de formas rítmicas mais livres, suscetíveis de dar um campo mais vasto ao novo tom do poeta, o poeta da rua"76. Khardjiev comenta que nessa categoria de rimas, "uma palavra provida de significado rima com um grupo formado de duas palavras independentes, sendo que a última corresponde a uma ou mais sílabas

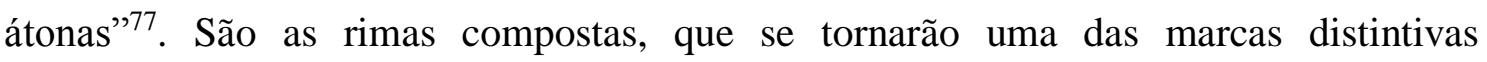
fundamentais do sistema de rimas nas obras mais maduras de Maiakóvski. O efeito sonoro é de rimas que reverberam no interior das próprias palavras.

Para ilustrar um pouco o nosso método de tradução e a importância da rima na construção do sentido, tomemos alguns exemplos do prólogo, cujo título é a interrogação “Sobre o quê - sobre isto?". Ele encerra-se com reticências, deixando em suspenso o tema do poema, tantas vezes cantado: o amor. É interessante notar que tal termo não aparece nenhuma vez nessa seção, mas, pelo artifício da rima, Maiakóvski o sugere ao leitor:

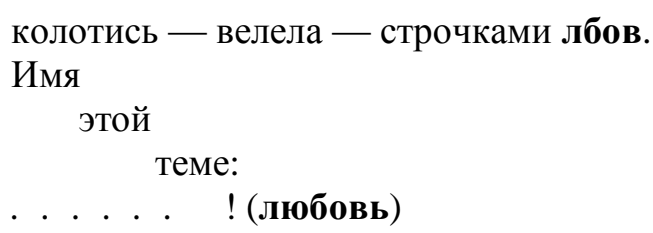

O termo liubov' / любов , “amor", é substituído por reticências, mas o termo lbov' / лбов, "testa", alguns versos antes antecipa e invoca a palavra calada. A solução que encontramos foi empregar um termo que também rimasse com amor e que se encaixasse no verso original. Cada linha do poema é como um bater de cabeça pelo desespero, então escolhemos "dor":

crava - ordenou - as frontes com os versos da dor

O nome

deste

tema

(amor)

\footnotetext{
${ }^{76}$ Khardjiev, N., op. cit., p. 270.

${ }^{77}$ Khardjiev, N., op. cit., p. 270-1.
} 
Retornando à primeira estrofe, que introduz a longa apresentação do tema, temos:

В этой теме,

личной

и мелкой,

перепетой не раз

и не пять,

я кружил поэтической белкой

и хочу кружиться опять.

Inicialmente recuperamos as rimas em "oi / ой” por meio do emprego de palavras terminadas em "-al", associando os mesmos termos e versos do original, com exceção de uma, explicitada adiante. O desafio maior, entretanto, é a recuperação de um recurso típico do poeta: Maiakóvski desdobra as palavras e as retoma versos depois com novo sentido: piát' / пять, “сіnco", está contida em opiát'/ опять, "novamente”. Este jogo de "eco" é mais profundo e complexo do que a rima "simples" e se trata de um recurso extremamente eficaz na obtenção do ritmo.

Como solução parcial, substituímos o advérbio "novamente" pela expressão "com mais afinco" que expressa a vontade do eu-lírico de manter o movimento e garante a rima, embora não contenha totalmente a palavra "cinco" no seu interior.

Neste tema,

pessoal

e banal,

cantado não uma vez

mas cinco,

como um poeta esquilo girei em espiral

e vou girar com mais afinco. 
Introduzimos a expressão "em espiral” para garantir a rima do verso como no original e por entendermos que não feria seu sentido já que integra o campo semântico do verbo "girar".

O quadro abaixo aponta outros exemplos, não exaustivos, das soluções encontradas na tradução das rimas ao longo do poema, com os respectivos comentários:

\begin{tabular}{|c|c|c|c|}
\hline Verso & $\begin{array}{c}\text { Original em russo e } \\
\text { transliteração }\end{array}$ & Solução tradutória & Comentários \\
\hline vv. 389 / 392 & Барахло одеяло / Вяло & Velho cobertor. / Estupor. & $\begin{array}{l}\text { Nesses versos, a rima foi mantida tal e } \\
\text { qual a original: mesmo lugar e termos. A } \\
\text { manutenção do som pela rima expressa a } \\
\text { inércia da cena. }\end{array}$ \\
\hline vv. $511 / 512$ & $\begin{array}{l}\text { Семь лет я стою / Я смотрю в } \\
\text { эти воды } \\
\text { Sem' let ia stoiu / Ia smotriu v } \\
\text { eti vody }\end{array}$ & $\begin{array}{l}\text { Há sete ano aqui me conservo } \\
\text { / Observo essas águas }\end{array}$ & $\begin{array}{l}\text { Exemplo de consonância não final } \\
\text { recuperada na tradução. Além da } \\
\text { terminação idêntica, o som inicial } \\
\text { também ecoa, traço que se perdeu na } \\
\text { tradução. A permanência do homem na } \\
\text { ponte é expressa pelo som que se mantém } \\
\text { no verso seguinte. }\end{array}$ \\
\hline vv. 646 / 648 & $\begin{array}{l}\text { прохожим / только вышел } \\
\text { похожим } \\
\text { prokhojim / tol'ko vychel } \\
\text { pokhojim }\end{array}$ & $\begin{array}{l}\text { passante / } \\
\text { sou apenas semelhante }\end{array}$ & $\begin{array}{l}\text { O segundo termo está todo contido no } \\
\text { primeiro. A solução foi rimar apenas as } \\
\text { terminações, associando os mesmos } \\
\text { termos. A rima, neste caso, reforçando a } \\
\text { ideia da semelhança física. }\end{array}$ \\
\hline vv. 886 / 887 & $\begin{array}{l}\text { зал заливался минуты две / } \\
\text { Медведь } \\
\text { zal zalivalsia minuty dve / } \\
\text { Medved' }\end{array}$ & $\begin{array}{l}\text { o lamento de um discurso: / } \\
\text { - Urso }\end{array}$ & $\begin{array}{l}\text { As modificações foram grandes para } \\
\text { alcançar um resultado semelhante: um } \\
\text { termo que integra o outro. }\end{array}$ \\
\hline vv. 955 / 956 & $\begin{array}{l}\text { впряженный в алую рамку / } \\
\text { и то тащил обывательства } \\
\text { лямку }\end{array}$ & $\begin{array}{l}\text { atrelado à rubra moldura / } \\
\text { arrastava os grilhões da usura }\end{array}$ & $\begin{array}{l}\text { Na verdade, a rima associava "moldura" a } \\
\text { "grilhões": ambos aprisionam Marx na }\end{array}$ \\
\hline
\end{tabular}




\begin{tabular}{|c|c|c|c|}
\hline & $\begin{array}{l}\text { vpriajennyi v aluiu ramku / i to } \\
\text { tachtchil obevatel'stva liamku }\end{array}$ & & $\begin{array}{l}\text { sala dos homens NEP. A solução foi rimar } \\
\text { com o termo anterior. }\end{array}$ \\
\hline vv. 1092 / 1094 & $\begin{array}{l}\text { атакую и вкривь и вкось / } \\
\text { слова проходят насквозь } \\
\text { atakuiu i vkriv' i vkos' / slova } \\
\text { prokhodiat naskvoz' }\end{array}$ & $\begin{array}{l}\text { ataco a torto e a direito / } \\
\text { as palavras penetram sem } \\
\text { efeito }\end{array}$ & $\begin{array}{l}\text { Não é uma rima perfeita, mas um jogo } \\
\text { com os mesmos sons nos dois termos. Os } \\
\text { sons ricocheteiam como as palavras do } \\
\text { poeta. Na verdade, no orginal, a expressão } \\
\text { "vkriv' i vkos' / вкривь и вкось" poderia } \\
\text { ser traduzida literalmente como "a torto e } \\
\text { de través", enquanto "naskvoz' / } \\
\text { насквозь" seria "através, direto" Há, } \\
\text { portanto, uma associação entre o ataque } \\
\text { desordenado e seu efeito contrário. } \\
\text { Preferirmos empregar a expressão } \\
\text { corriqueira em português "a torto e a } \\
\text { direito", pois ela significa justamente "de } \\
\text { modo aleatório". }\end{array}$ \\
\hline vv. 1593 / 1597 & $\begin{array}{l}\text { гусар! / Не празднуй труса! } \\
\text { gusar! / Ne prazdnui trusa! }\end{array}$ & $\begin{array}{l}\text { um hussardo !/ } \\
\text { Não banque o covarde !- }\end{array}$ & $\begin{array}{l}\text { A rima no original não é perfeita, } \\
\text { mantivemos assim na tradução. Os } \\
\text { inimigos insultam o herói e associam } \\
\text { "hussardo" a "covarde". }\end{array}$ \\
\hline vv. $1686 / 1688$ & $\begin{array}{l}\text { лаву раскатил, горящ и } \\
\text { каменист / медведь- } \\
\text { коммунист } \\
\text { lavu raskatil, goriachtch i } \\
\text { kamenist / medved'- } \\
\text { kommunist }\end{array}$ & $\begin{array}{l}\text { role a lava pétrea e foguista / } \\
\text { urso-comunista }\end{array}$ & $\begin{array}{l}\text { Mais uma vez, há um complexo jogo } \\
\text { sonoro em que apenas duas vogais fazem } \\
\text { a diferença na semelhança. Não } \\
\text { conseguimos manter a associação original } \\
\text { pétrea / comunista, mudamos a sintaxe e } \\
\text { recriamos foguista / comunista. Apesar de } \\
\text { o termo não ser tão corrente em } \\
\text { português, decidimos empregá-lo, pois a } \\
\text { rima, neste caso, era essencial, na medida } \\
\text { em que expressa a visão de Maiakóvski } \\
\text { acerca do comunismo: sua força é } \\
\text { associada a elementos da natureza. Além } \\
\text { disso, como o poeta defendia rimas } \\
\text { surpreendentes e aproveitava todo o } \\
\text { material poético, acreditamos que o }\end{array}$ \\
\hline
\end{tabular}




\begin{tabular}{|c|c|c|c|}
\hline & & & $\begin{array}{l}\text { emprego não fere seus princípios de } \\
\text { composição. }\end{array}$ \\
\hline vv. 1691 / 1694 & $\begin{array}{l}\text { кожа на моих руках тонка / и } \\
\text { не увидав токарного станка } \\
\text { koja na moikh rukakh tonka / i } \\
\text { ne uvidav tokarnogo stanka }\end{array}$ & $\begin{array}{l}\text { a pele das minhas mãos é terna } \\
\text { / e sem nunca ter visto um } \\
\text { torno }\end{array}$ & $\begin{array}{l}\text { Apenas um som difere entre os termos no } \\
\text { original, a solução apresenta um } \\
\text { procedimento parecido. A rima realça a } \\
\text { oposição entre as mãos delicadas e do } \\
\text { trabalho braçal. }\end{array}$ \\
\hline vv. 1833 / 1836 & $\begin{array}{l}\text { А на что мне сажень? / Для } \\
\text { таких работ годна и тля. / } \\
\text { Перышком скрипел я, в } \\
\text { комнатенку всажен, / } \\
\text { вплющился очками } \\
\text { комнатный футляр. } \\
\text { A na chto mne sajen'? / Dlia } \\
\text { takikh rabot godna i tlia. / } \\
\text { Perychkom skripel ia, v } \\
\text { komnatenku vsajen, } \\
\text { vpliuchtchilsia otchkami v } \\
\text { komnatnyi futliar. }\end{array}$ & $\begin{array}{l}\text { De que me serviu essa altura? } \\
\text { / Uma pulga teria mais arrojo. / } \\
\text { Rangendo a pena no quarto em } \\
\text { clausura, / dobrado feito } \\
\text { óculos no quarto estojo. }\end{array}$ & $\begin{array}{l}\text { A passagem é bastante rica em elementos } \\
\text { sonoros, mas grafamos somente o que } \\
\text { conseguimos recuperar, de certa forma, } \\
\text { na tradução. Duas alternativas seriam: } \\
\text { Para esses trabalhos uma pulga basta. / } \\
\text { dobrado feito óculos no quarto caixa., ou } \\
\text { Para esses trabalhos uma pulga basta. / } \\
\text { achatado feito papel no quarto pasta. } \\
\text { embora recuperem a sonoridade, elas } \\
\text { perdem a alusão imediata ao conto de } \\
\text { Tchékhov (ver nota à tradução 182). } \\
\text { Substituímos "trabalhos" por "arrojo" } \\
\text { para garantir a rima e a referência. A } \\
\text { grande estatura do poeta contrapõe-se ao } \\
\text { quarto apertado, sua grande poesia ligada } \\
\text { à vida não é aquela do intelectual alienado } \\
\text { da realidade. }\end{array}$ \\
\hline vv. 1896 / 1898 & $\begin{array}{l}\text { Она красивая - / } \\
\text { ее, наверно, воскресят. }\end{array}$ & $\begin{array}{l}\text { como está lá na foto sobre a } \\
\text { mesa / Ela é bonita - / na certa } \\
\text { eles vão ressuscitá-la }\end{array}$ & $\begin{array}{l}\text { O jogo do original foi apenas } \\
\text { parcialmente reproduzido, mas manteve o } \\
\text { elo entre os termos originais. }\end{array}$ \\
\hline vv. 1909 / 1913 & $\begin{array}{l}\text { откинул будничную чушь! / } \\
\text { свое дожить хочу! }\end{array}$ & $\begin{array}{l}\text { recusando o absurdo usual / } \\
\text { quero viver a vida até o final }\end{array}$ & $\begin{array}{l}\text { Recuperação parcial do original: a rima } \\
\text { garantiu a sonoridade dos mesmos versos, } \\
\text { mas não manteve a mesma associação de } \\
\text { termos. }\end{array}$ \\
\hline
\end{tabular}




\begin{tabular}{|c|c|c|c|}
\hline & $\begin{array}{l}\text { Otknul budnitchnuiu tchuch'! } \\
\text { / svoio dojit' khotchu! }\end{array}$ & & \\
\hline vv. 1917 / 1919 & $\begin{array}{l}\text { Чтоб не было любви - } \\
\text { сужанки / хлебов. / встав с } \\
\text { лежанки, } \\
\text { чтоб всей вселенной шла } \\
\text { любовь. } \\
\text { Tchtob ne bylo liubvi - } \\
\text { slujanki / khlebov. / vstav s } \\
\text { lejanki, tchtob vcei vcelennoi } \\
\text { chla liubov, }\end{array}$ & $\begin{array}{l}\text { Para que o amor não seja } \\
\text { escravo de casamento, / de } \\
\text { luxúria, / de pão, / Maldizendo } \\
\text { as camas, / } \\
\text { afastando-se do fogão, / para } \\
\text { que o universo revista-se de } \\
\text { amor. / Para que no dia, / em } \\
\text { que envelhecer de dor, }\end{array}$ & $\begin{array}{l}\text { Trecho de difícil recuperação. A } \\
\text { associação inicial era entre escravidão / } \\
\text { cama disposta sobre forno típico russo e } \\
\text { entre pão / amor. Associamos termos } \\
\text { diferentes. }\end{array}$ \\
\hline vv. 1933 / 1936 & $\begin{array}{l}\text { отныне / стать / } \\
\text { землей по крайней мере - } \\
\text { мать. } \\
\text { otnyne / stat' / zemlei po } \\
\text { krainei mere-mat' }\end{array}$ & $\begin{array}{l}\text { após essa era que se encerra / } \\
\text { a mãe, - no mínimo a terra }\end{array}$ & $\begin{array}{l}\text { A melhor solução que encontramos } \\
\text { envolveu alteração da sintaxe e quebra do } \\
\text { princípio da economia, com acréscimo de } \\
\text { elementos no verso. }\end{array}$ \\
\hline
\end{tabular}

Outro recurso que se combina à rima para o reforço do sentido são as aliterações. Maiakóvski compartilhava o princípio da "estrutura pesada e difícil", quebrando os paradigmas da beleza e suavidade da linguagem. As construções consonantais ásperas representavam a violência e velocidade do movimento. Khardjiev afirma que Maiakóvski “criou uma nova forma de aliteração expressiva na qual as chiantes sublinham a entonação furiosa e acusadora"78. Segundo ele, "nenhum poeta russo havia empregado

\footnotetext{
${ }^{78}$ Khardjiev, N. "Sur les répétitions de sons et les allitérations". In : Khardjiev, N., Trenine, V., op. cit., p.
} 289. 
com tamanha perseverança e continuidade sucessões obstinadas de consoantes chiantes, sobretudo as fricativas [j] [ch] [kh] e as africadas [tch]"79.

Entretanto, mais uma vez prevalece o preceito de economia na arte. O próprio poeta afirma que

o excesso de consonâncias, aliterações, etc. cria após os primeiros instantes de leitura, uma impressão de enfaramento [...] é preciso dosar a aliteração com um máximo de cautela e, sempre que possível, evitar as repetições gritantes. [...] Recorro à aliteração como um meio de emoldurar uma palavra importante para mim e de sublinhá-la ainda mais ${ }^{80}$.

Novamente, a título de exemplo, marcamos, os sons que se destacam neste trecho do prólogo. Há uma profusão de palatais, sibilantes e do som [i] que tentamos recuperar através do emprego de termos igualmente ricos em palatais, plosivas e [i] como figura abaixo:

Эта тема придет,

калеку за локти

подтолкнет к бумаге,

прикажет:

$$
\text { - Скреби! - }
$$

И калека

с бумаги

срывается в клёкоте,

только строчками в солнце песня рябит.

Este tema chega

às cotoveladas instiga

o mutilado pr'o papel,

ordena:

${ }^{79}$ Idem, ibidem.

${ }^{80}$ Idem, ibidem. 
-Fira!

E o mutilado,

do papel

desprende-se num grito de rapina,

só com as linhas a canção rebate o sol.

O quadro abaixo reúne mais alguns exemplos de tradução de versos marcados por aliterações e assonâncias. Certamente, nem sempre recuperamos os mesmos sons na tradução, mas buscamos soluções que reproduzissem a mesma concepção do original:

\begin{tabular}{|c|c|c|}
\hline Verso & Original russo e transliteração & Tradução \\
\hline v. 126 & $\begin{array}{l}\text { звонок от ожочов уже визжит } \\
\text { zvonok ot ojotchov uje vizjit }\end{array}$ & a campainha já geme pelas chamas \\
\hline v. 133 & $\begin{array}{l}\text { мясом дынясь, сжимаю жжение } \\
\text { miasom dynias', sjimaiu jjenie }\end{array}$ & $\begin{array}{l}\text { com a carne em chamas, pressiono as } \\
\text { chagas }\end{array}$ \\
\hline v. 190 & $\begin{array}{l}\text { раструба трубки разинув оправу } \\
\text { rastruba trubki razinuv opravu }\end{array}$ & $\begin{array}{l}\text { aberto o aro da boca do tubo } \\
\text { * como a sua poesia é essencialmente } \\
\text { oral e voltada para a declamação, levou- } \\
\text { se em conta a pronúncia do português } \\
\text { brasileiro dos sons grafados, que } \\
\text { apresentam um alçamento da vogal final } \\
\text { "o", pronunciado como "u". }\end{array}$ \\
\hline v. 383 & $\begin{array}{l}\text { винтовки-шишки } \\
\text { vintovki-chichki }\end{array}$ & espingardas-pinhas \\
\hline v. 395 & $\begin{array}{l}\text { простынь постельная треплется } \\
\text { плеском } \\
\text { prostyn' postel'naia trepletsa } \\
\text { pleskom }\end{array}$ & o lençol do leito balança e balbucia \\
\hline
\end{tabular}




\begin{tabular}{|c|c|c|}
\hline v. 429 & $\begin{array}{llll}\text { как ветер воет вдогонку с } \\
\text { ладоги } & & \\
\text { kak véter vóet vdogonku } & \text { s } \\
\text { Ladogui } & & & \end{array}$ & $\begin{array}{l}\text { como uiva o vento vindo do Ládoga no } \\
\text { teu vestígio }\end{array}$ \\
\hline v. 484 & $\begin{array}{l}\text { опершись о перила моста } \\
\text { operchis' o perila mosta }\end{array}$ & aparado no parapeito da ponte \\
\hline v. 591 & $\begin{array}{l}\text { спасите! - сигналю ракетой слов } \\
\text { spasite! - signaliu raketoi slov }\end{array}$ & $\begin{array}{l}\text { Socorro ! - a saraivada de palavras } \\
\text { ressalta o sinal. }\end{array}$ \\
\hline vv. 687-692 & $\begin{array}{l}\text { шел / вдруг/ встал / в шелк / рук } \\
\text { / сталь } \\
\text { chiol / vdrug / vstal / v chiolk / ruk } \\
\text { / stal' }\end{array}$ & $\begin{array}{l}\text { Seguia / subitamente / cessou. / na seda } \\
\text { /das mãos /o aço. }\end{array}$ \\
\hline v. 1090 & вбиваюсь слов напором & bato com a bomba das letras \\
\hline v. 1118 & $\begin{array}{l}\text { скутан саваном } \\
\text { skutan savanom }\end{array}$ & cerrado em um sudário \\
\hline v. 1122 & $\begin{array}{l}\text { их шорох тишью стерт весь } \\
\text { ikh chorokh tich'iu stert ves' }\end{array}$ & seu sussurro esvai-se no silêncio \\
\hline v. 1643 & $\begin{array}{l}\text { векам-Араратом } \\
\text { vekam-Araratom } \\
\text { * о "o" átono pronuncia-se como } \\
\text { "a" }\end{array}$ & eras -Ararates \\
\hline v. 1645 & $\begin{array}{l}\text { кобчегом-кобшом } \\
\text { kobtchegom-kobchom }\end{array}$ & arca-concha \\
\hline v. 1910 & $\begin{array}{l}\text { и откинул будничную чушь } \\
\text { i otkinul budnitchnuiu tchuch' }\end{array}$ & recusando o absurdo usual \\
\hline
\end{tabular}

Como vimos, os versos de Maiakóvski se destinam à voz, à recitação diante do público, constroem-se não sobre acentos métricos mas sobre os das palavras, sobre os 
acentos da língua falada. ${ }^{81}$ Um ponto importantíssimo da sua concepção sobre os versos é a questão do ritmo. Para ele há a repetição de um som, um ruído primordial, e o poeta deve esforçar-se para organizá-los, como postulava seu amigo, o formalista Óssip Brik em Ritmo e Sintaxe. Para o teórico, "o movimento rítmico é anterior ao verso" 82 e "no poeta, aparece antes a imagem indefinida de um complexo lírico dotado de estrutura fônica e rítmica e só depois essa estrutura transracional articula-se em palavras significantes." $" 83$

No ensaio "Como fazer versos", Maiakóvski revela que antes de pensar nas inúmeras possibilidades sonoras e rítmicas do poema concretizado, sente continuamente um ritmo primordial:

A medida se produz em mim em consequência da cobertura desta zoada rítmica, com palavras propostas pelo encargo social (o tempo todo, você se interroga: é esta a palavra certa? A quem vou lê-la? E será compreendida corretamente? Etc. $)^{84}$.

A sonoridade é, pois, a expressão material de um ritmo vital que antecede a composição do poema: “O ritmo é a força básica, a energia básica do verso. Não se pode explicá-lo, disto só se pode falar como se fala do magnetismo ou da eletricidade, o magnetismo e a eletricidade são formas de energia." 85

Em sua poesia o ritmo é garantido pelo emprego de muitos recursos sonoros, especialmente, como vimos, as rimas inesperadas e ousadas, as rimas compostas e as rimas com número desigual de sílabas ${ }^{86}$, as aliterações apoiadas nas estruturas pesadas e o jogo acentual. O pesquisador soviético Chtokmar defendeu a rima como a "genuína força motora do verso livre de Maiakóvski". ${ }^{87}$

\footnotetext{
${ }^{81}$ Khardjiev, N, Trenine, V., op. cit., p. 232.

${ }^{82}$ Brik, O., op. cit., p. 132.

${ }^{83}$ Idem, p. 137.

${ }^{84}$ Maiakóvski, V. op. cit., p. 188.

${ }^{85}$ Maiakóvski, V. op. cit., p. 187.

${ }^{86}$ Khardjiev, N, Trenine, V., op. cit., p. 231.

${ }^{87}$ Chtokmar, M. P. "O stikhoi sisteme Maiakovskogo”. (Sobre o sistema de versos de Maiakóvski), p. 303. In: Chtokmar, M. P. Tvortchestvo Maiakovskogo (A Obra de Maiakóvski). Moscou: 1952, p. 303 apud Peterson, op. cit., p. 419.
} 
Para criar 'a palavra objetual', 'a palavra rude', isto é, fisicamente tangível [...]”88, imprimia o ritmo das marchas e tambores. Tal ritmo era obtido com o emprego da "sequência sonora pesada" 89 e de aliterações de sons consonantais. À forma pesada ele aliava o encargo social.

Não se importava com os metros consagrados. Afirmou:

Não conheço nem iambos nem troqueus, nunca os diferenciei, nem vou diferenciá-los. Não porque seja trabalho difícil, mas porque nunca precisei lidar com essas coisas em meu trabalho poético. E se os fragmentos desses metros se encontram no que escrevi, trata-se apenas de algo anotado de oitiva, pois essas melodias cacetes se encontram com demasiada frequência. ${ }^{90}$

Schnaiderman", em nota ao ensaio "Como fazer versos", resume a pesquisa de Kondratov acerca do ritmo e da métrica do poeta. Há diversos tipos fundamentais de organização rítmica do verso maiakovskiano. Dentre eles, o dólnik - verso tônico, mas em que "o número de sílabas não acentuadas, embora não tenha regularidade absoluta, segue certa norma" - serve de verso fundamental para escrever ora poemas inteiros, ora longos trechos e ele tem função importante no poema Sobre Isto. O dólnik geralmente marca a narração.

Com efeito, o que se observa é a polimetria, a alternância de grupos de versos curtos e longos, cuja estrutura tentamos, geralmente, reproduzir com tetrassílabos, redondilhas ou octossílabos - típicos da oralidade e das formas populares, como a balada -, ou com decassílabos, dodecassílabos e versos ainda mais longos. O importante foi manter, no conjunto, o tom oral e coloquial. Roman Jakobson vê no âmago do verso declamatório de Maiakóvski um retorno às narrativas populares russas que não levam em conta as escansões acadêmicas e privilegiam a oralidade. ${ }^{92}$

\footnotetext{
${ }^{88}$ Pomorska, op. cit., p. 149.

${ }^{89}$ Não por acaso, quando montou a peça O Percevejo (1928) com Meyerhold, pediu a Chostakóvitch que compusesse a música inspirado nas marchas dos bombeiros. Cf. Katanian, V. Maiakóvski: litieratúrnaia khrónika (3 ${ }^{\text {a }}$ edição), Moscou, 1956, p. 369 apud Ripellino, A. M., op. cit., p. 186.

${ }^{90}$ Maiakóvski, V. op. cit., p. 173.

${ }^{91}$ Maiakóvski, V. op. cit., nota 23, p. 212.

${ }^{92}$ Perterson, op. cit., p. 419.
} 
Selecionamos alguns excertos para ilustrar a variedade métrica do poema. No trecho abaixo, optamos por versos mais breves, numa alternância de trissílabo/redondilha maior/trissílabo/redondilha menor/tetrassílabo.

Como um urso

mortalmente enfurecido,

puxo o peito

contra o telefone,

meu inimigo.

(vv. 350-354)

Nestes versos a redondilha maior garantiu o ritmo popular e oral:

No travesseiro - polar

naveguei pelo Nevá -

(vv. 999-1000)

Outro trecho irregular, que alterna redondilha maior/hexassílabo/endecassílabo/ decassílabo:

Velha lábia da balada,

mas se as palavras lanham

e as palavras falam sobre isto, que lanham,

rejuvenesce a lábia da balada.

(vv. 88-91)

A seguir dois trechos diversos que apresentam versos mais longos, no padrão decassílabo/dodecassílabo:

desprende-se num grito de rapina,

só com as linhas a canção rebate o sol.

(vv. 31-32)

Com a carne em chamas, pressiono as chagas.

Num átimo o relâmpago atravessa o corpo.

(vv. 133-134) 
Maiakóvski era a favor da economia na arte, ou seja, suprimia o que parecia supérfluo, mantendo o essencial. O essencial para o seu encargo social. Embora os poemas narrativos como Sobre Isto não sejam concisos em sua extensão, pode-se falar, sim, em economia, na medida em que Maiakóvski faz largo uso das construções elípticas que dinamizam o verso, surpreendem e, às vezes, turvam a compreensão. No campo das imagens, Vizioli" ${ }^{93}$ defende que "é necessário transpor o termo em sua estranheza" e que "o apagamento dessa estranheza pela introdução de elementos da língua-cultura de chegada significa que se saiu do domínio da tradução para entrar no da adaptação literária”. Para Antoine Berman uma má tradução desconsidera o elemento estrangeiro e tende à naturalização. ${ }^{94}$ Acreditamos que a mesma postura deve se verificar na tradução da sintaxe típica do original, evitando romper a obliquidade da significância ${ }^{95}$ do poema, por meio de explicações excessivas.

Novamente recorremos aos estudos dos manuscritos empreendidos por Khardjiev e Trenin, que perceberam uma tendência essencial à expressividade lacônica ${ }^{96}$. Aí reside uma certa contradição: se por um lado sua poesia é oral, por outro a sintaxe de Maiakóvski é rica em locuções que não se encontram na língua falada. Daí, por exemplo, a supressão frequente das preposições. Não raro, Maiakóvski "remaneja as partes de um poema, rompe a unidade das construções sintáticas e acentua, assim, seu dinamismo"97.

Na tradução tentamos manter as mesmas construções e não desenvolver as elipses, como demonstram os exemplos a seguir:

Antessala trevas.

Cômodo eletricidade.

(vv. 749-750)

Por que prisão?

Natal.

Confusão.

(vv. 108-110)

\footnotetext{
${ }^{93}$ Vizioli, P.“ A Tradução de Poesia em Língua Inglesa”. Tradução \& Comunicação, 2, 1985 apud Faleiros, A. Traduzir o poema. São Paulo: Ateliê, 2012, p. 31.

${ }^{94}$ Berman, A. A prova do estrangeiro. Trad. Maria Emília Pereira Chanut, Bauru, Edusc, 2002 (1984. apud Faleiros, A., 17

${ }^{95}$ Noção desenvolvida por Mário Lanajeira, op. cit., p. 24.

${ }^{96}$ Khardjiev, N, Trenine, V., op. cit., p. 246.

${ }^{97}$ Idem, p. 247.
} 
Parque Petróvski.

Corro.

Khodynka

em minha jugular.

(vv. 623-626)

Noite sem luz,

não vejo um palmo diante do nariz.

Lua.

Sob mim

o Machuk de gelo.

(vv. 1536-1540)

O princípio da economia também comanda os recursos sonoros, que empregamse atrelados ao sentido e não somente como acessórios estéticos. Dizia: "não é obrigatório ornar o poema com aliterações rebuscadas e rimá-lo do início ao fim de maneira inusitada. Lembrem-se constantemente de que o regime de economia na arte é sempre uma regra importantíssima para toda produção de valores estéticos" $" 98$. Mais uma característica a ser observada na tradução: os recursos sonoros devem ser recuperados com bom senso. Norteamo-nos por essa visão para não exagerar e não ornar mais do que o próprio poeta o fizera. Como bem observaram Khardjiev e Trenin, “os elementos sonoros não constituem para Maiakóvski um fim em si mesmo, mas serviam para reforçar e enriquecer o sentido do verso." 99

A velocidade imprime-se também no verso, não apenas foneticamente, mas também grafica e sintaticamente. As semi-linhas asseguram o ritmo, o sentido, facilitam a reprodução oral ${ }^{100}$ e conferem ao poema o status de objeto gráfico. Dizia que com

\footnotetext{
${ }^{98}$ Maiakóvski, V., op. cit., p. 198

${ }^{99}$ Khardjiev, N., Trenine, V., op. cit., p. 249.

${ }^{100}$ Concebido para ser declamado, o verso de Maiakóvski apoia-se totalmente na voz. Cf. Trénine, V., op. cit., p. 248.
} 
a divisão em semi-linhas, não haverá nenhuma confusão, quer de ritmo, quer de sentido. A divisão das linhas é ditada às vezes também pela necessidade de estabelecer o ritmo sem possibilidade de erro, pois a nossa construção do verso, condensada e econômica, obriga frequentemente a eliminar palavras e sílabas intermediárias, e se depois dessas sílabas não se fizer uma pausa, com frequência maior que aquela que se faz entre os versos, o ritmo ficará rompido ${ }^{101}$

As peculiaridades tipográficas de Maiakóvski, como as semi-linhas, têm como efeito mais imediato o estímulo a uma determinada declamação, pois forçam o leitor a uma "enunciação retórica precisa"102 de determinadas passagens do poema. Elas destacam palavras e expressões isolando-as e evitando que se percam em meio ao verso. Peterson $^{103}$ diz que o outro lado do procedimento é a origem de uma sintaxe violenta que reforça o impacto do grotesco, do burlesco, do hiperbólico e do nonsense.

Outra característica verificada e que se tentou recuperar na tradução foi a pontuação. Maiakóvski afirmou que "a nossa pontuação habitual, com pontos, vírgulas, sinais de interrogação e de exclamação, é demasiado pobre e pouco expressiva" ${ }^{104}$ a medida e o ritmo da obra são mais significativos que a pontuação. Tentamos não acrescentar a pontuação quando ela não existia no original, ainda que tal decisão engendre, às vezes, um estranhamento em português.

Filhotinhos da campainha

ricocheteando

aos milhares

das paredes

sob as cadeiras e as camas

cambaleavam.

(vv. 197-202)

puxo o peito

\footnotetext{
${ }^{101}$ Maiakóvski, V., op. cit., p. 199.

${ }^{102}$ Perterson, op. cit., p. 421.

${ }^{103}$ Idem, ibidem.

${ }^{104}$ Maiakóvski, V., op. cit., p. 199.
} 
contra o telefone

meu inimigo.

(vv. 350-354)

Aos amados,

amigos

pessoas em listras

a todo o universo guiou com o sinal.

(vv. 1550-1553)

A velocidade do verso, a oralidade da linguagem, a recuperação de jargões, gírias, palavrões e a criação de neologismos, a aproximação dos opostos, a exploração do dissonante, a linguagem das ruas, o cotidiano das manchetes, a escolha das imagens guiada pela expressividade e, não raro, a paródia e a estilização com o intuito de caricaturar: tudo era poesia em potencial. Não havia tema ou palavra inadequada à poesia, tudo se transformava em material poético. A poesia permeava inclusive os slogans publicitários que desenvolvia para a loja estatal de departamentos Masselprom e as janelas Rosta, enormes cartazes informativos que confeccionava durante os anos pósrevolucionários.

Pomorska afirma que "Maiakóvski foi conhecido antes de tudo como um poeta que 'rebaixou' a linguagem poética, dando-lhe uma forte infusão de coloquialismos e jargões citadinos" 105 . A este respeito, o próprio poeta afirmou que a maior parte dos seus trabalhos "está construída segundo uma entonação coloquial"106. Segundo Khardjiev, Maiakóvski louvava o nascimento de novas palavras criadas pela revolução, em virtude do desenvolvimento de novas relações sociais. Ele empregava neologismos soviéticos que muitas vezes "serviam de material para a construção de imagens grandiosas e líricas carregadas de emoção" ${ }^{107}$.

Tchukóvski notou que Maiakóvski foi ampalmente inspirado por seu "rival" Severiánin, baluarte do egofuturismo russo. Citado em La culture poétique de Mä̈akovski, o teórico aponta alguns exemplos de neologismos criados a partir de bases

\footnotetext{
105 Pomorska, op. cit., p. 149.

${ }^{106}$ Maiakóvski, V., op. cit., p. 198.

${ }^{107}$ Khardjiev, N., Trenine, V. "Maïakovski et la lange” In : Khardjiev, N., Trenine, V., op. cit., p. 318.
} 
verbais e adjetivas ${ }^{108}$, como ogromnit' / огромить, cuja raiz remete à grom / гром, "raio", е ovazit'sia / овазиться, oriundo de vaza / ваза, “соро", literalmente "adquirir a forma de um copo". Outros exemplos levantados por Tchukóvski são: olunit'/ олунить, de luna / луна, “lua”, algo como “enluar”, okalochit' / окалошить, de kalochi / калоши, "galochas" ou "engalochar". Demos atenção especial aos neologismos na tradução e o processo das soluções encontra-se detalhado nas notas à tradução.

Em "Nosso trabalho vocabular" Maiakóvski afirma que "A poesia e a prosa dos antigos estavam igualmente afastadas da fala prática, do jargão das ruas, da linguagem exata da ciência. Seu objetivo era, portanto, dissipar "a velha poeira vocabular, aproveitando apenas a tralha de ferro das velharias." Também era sua a busca da fidedignidade: "Todo este trabalho não é para nós um fim em si estético, mas um laboratório para a melhor expressão dos fatos da atualidade." ${ }^{109} \mathrm{Um}$ exemplo contundente no poema é o emprego da expressão "filho de uma nep" (v. 639), na qual Maiakóvski reúne a coloquialidade do insulto e a atualidade histórica.

Muitos outros aspectos e exemplos poderiam ser extraídos do poema, seja em termos rítmicos e sonoros, seja do ponto de vista do conteúdo que expressa a visão revolucionária de Maiakóvski no que se refere às relações humanas. Nossa seleção tentou depreender os principais elementos da sua poética e dos seus ideais. Buscamos, assim, explicitar os princípios poéticos norteadores da nossa tradução, que consideramos como um processo contínuo. Certamente, leituras futuras ensejarão outras soluções, mas os preceitos poéticos serão sempre aqueles valorizados pelo poeta russo.

Maiakóvski vaticina o homem do futuro com sua poesia do futuro. Jakobson tinha razão: “a poesia de Maiakóvski é qualitativamente diferente de tudo o que foi o verso russo antes dele, [..] a estrutura da sua poesia é profundamente original e revolucionária" ${ }^{110}$ Poeta visionário, indiscutível voz da modernidade, é sempre um prazer e uma grande descoberta ressuscitá-lo a cada leitura.

\footnotetext{
108 Tchukóvski sustenta que a base adjetiva era o meio de maior fertilização de Severiánin na obra de Maiakóvski. Cf. Khardjiev, N. "Gorki sur Maïakovski”. In: Khardjiev, N, Trenine, V., op cit., p. 295.

${ }^{109}$ Maiakóvski, V. "Nosso trabalho vocabular”. In: Schnaiderman, B. A poética de Maikóvski. São Paulo: Perspectiva, 1971, p. 222.

${ }^{110}$ Jakobson, R. A geração que esbanjou seus poetas. São Paulo: Cosac Naify, 2006, p. 9
} 


\section{REFERÊNCIAS BIBLIOGRÁFICAS}

\section{Obras de Maiakóvski}

Di questo. A lei e a me. Tradução e prefácio de Anna Omodei Zorini. Florença: Passigli, 2009.

De ça. [1923]. Tradução de Henri Deluy. Paris: Inventaire/Invention, 2008.

That's what. Tradução de Larisa Gureyeva e George Hyde. Introdução de John Wakeman. Nahholme Mill: Arc, 2009.

About this. In: Mayakovsky. Tradução de Herbert Marshall. London: Dennis Dobson, 1965, pp. 157-229.

Maiakóvski - Poemas. Tradução de Augusto e Haroldo de Campos e Boris Schnaiderman. São Paulo: Perspectiva, 2003.

Mistério-Bufo. Tradução de Arlete Cavaliere. São Paulo: Editora 34, 2012.

O Percevejo. Tradução de Luís Antonio Martinez Corrêa. São Paulo: Editora 34, 2009.

Poesie. Guido Carpi (org.). Introdução de Stefano Garzonio. Milano: Bur, 2010.

Pólnoie sobranie sotchinénii v trinádtsati tómakh. (Obra completa reunida em treze volumes). Moscou: Khudojestvennaia Literatura, 1955.

\section{Obras sobre Maiakóvski citadas na dissertação}

Cavaliere, A. O. “O Teatro de Maiakóvski: mistério ou bufo?”. In: Teatro Russo. Percurso para um estudo da paródia e do grotesco. São Paulo: Humanitas, 2009. 
Cavaliere, A., VÁssina, E., Andrade, H. F., Silva, N. (dir.). Caderno de Literatura e Cultura Russa, n. 1, março 2004. São Paulo: Ateliê, 2004.

ChKLóvski, V. “O Maiakovskom” (“Sobre Maiakóvski”). Moscou: 1940.

Chtokmar, M. P. “O stikhoi sisteme Maiakovskogo”. (Sobre o sistema de versos de Maiakóvski), p. 303. In: Chtokmar, M. P. Tvortchestvo Maiakovskogo (A Obra de Maiakóvski). Moscou: 1952.

Jangfeldt, B. La vie en jeu. Une biographie de Vladimir Maïakovski. Paris: Albin Michel, 2010. (org.) L'amore è il cuore di tutte le cose. Vladimir Majakovskij - Lili Brik. Vicenza: Neri Pozza, 2005.

KATANIAN, V. Maiakóvski: litieratúrnaia khrónika (3ª edição). Moscou: 1956.

Khardjiev, N. e Tretine, V. La culture poétique de Maïakovski. Tradução e prefácio de Gérard Conio. Lausanne : L'Age d'Homme, 1982.

Peterson, D. E.. "Mayakovsky and Whitman: The Icon and the Mosaic". In: Slavic Review, Vol. 28, № 3, setembro de1969, pp. 416-425. Association for Slavic, East European, and Eurasian Studies Stable. URL: http://www.jstor.org/stable/2494019 . Acesso em 22/09/2011.

RIPEllino, A. M. Maiakóvski e o Teatro Russo de Vanguarda. São Paulo: Perspectiva, 1971.

Schnaiderman, Boris. A Poética de Maiakóvski. São Paulo: Perspectiva, 1971.

TCHUKOvski, K. "Vladimir Maiakóvski”. In: Les Futuristes. Lausanne: L’Âge d'Homme, 1976.

Thomson, R. D. B.“Mayakovsky and his time imagery”. In: The Slavonic and East European Review, Vol. 48, №. 111, abril de 1970, pp. 181-200. Modern Humanities 
Research Association and University College London, School of Slavonic and East European Studies Stable. URL: http://www.jstor.org/stable/4206198, acesso em 22/09/2011.

\section{Obras sobre tradução citadas}

AZENHA, J. “Transferência cultural em tradução: contextualização, desdobramentos, desafios". TradTerm, 16, São Paulo, 2010, p. 37-66.

"Linguística textual e tradução: redefinindo o conceito de marca cultural”. TradTerm, 12, São Paulo, 2006, p. 13-32.

Berman, A. A prova do estrangeiro. Trad. de Maria Emília Pereira Chanut. Bauru, Edusc, 2002 [1984].

BEZERRA, P. “Tradução e criação. Linha d’Água, 25 (2), São Paulo, 2012, p. 15-23, 2012. Disponível em http://www.revistas.usp.br/linhadagua/article/view/47712/51447, acesso em julho de 2014.

BRITO, P. H. "Para uma avaliação mais objetiva das traduções de poesia". In: Krause, Gustavo Bernardo. As margens da tradução. Rio de Janeiro: FAPERJ/Caetés/UERJ, 2002.

"Tradução e criação". Maria Lúcia Vasconcellos (org.). Cadernos de Tradução n. IV. Florianópolis: UFSC, 1999. pp. 239-262.

"Uma forma humilde". Jornal de Resenhas n. 60. São Paulo: Folha de São Paulo, 11 de março de 2000.

CAMPOS, H. de. "Da tradução como criação e como crítica". In: Metalinguagem e outras metas. São Paulo: Perspectiva, 2010.

FALEIRos, A. Traduzir o poema. São Paulo, Ateliê, 2012. 
JAKOBSON, Roman. Aspectos linguísticos da tradução". In: Lingüística e Comunicação. São Paulo, Cultrix, s/d.

Lacoue- Labarthe, P. La poésie comme expérience. Paris: Christian Bourgois Ed., 1986.

Laranjeira, Mário. Poética da Tradução. Col. Criação \& Crítica no 12. São Paulo: Edusp, 2003.

Meschonnic, H. Poética do Traduzir. São Paulo: Perspectiva, 2010.

RoBel, L. “Transformer. Traduire.” Revista Change n. ${ }^{\circ}$ 14, fevereiro de 1973.

SChNAIDERman, B. Tradução, ato desmedido. São Paulo: Perspectiva, 2011.

Vizioli, P. “A Tradução de Poesia em Língua Inglesa: Problemas e Sugestões”, Tradução \& Comunicação, n. ${ }^{\circ}$ 2, 109-128, mar. 1983.

\section{Obras gerais citadas}

BRIK, O. "Ritmo e Sintaxe". In: Teoria da Literatura. Formalistas Russos. São Paulo: Globo, 1978.

Brunel, Pierre (org.). Dicionário de Mitos Literários. Rio de Janeiro: José Olympio, 1997.

CÂMARA JR., Joaquim Mattoso. Dicionário de linguagem e gramática. Petrópolis: Vozes, 1978.

Campos, Augusto e Haroldo e Schnaiderman, Bóris (org. e trad.). Poesia Russa Moderna. São Paulo: Perspectiva, 2001. 
DostoiÉvski, F. Crime e Castigo. Trad. de Paulo Bezerra. São Paulo: Ed. 34, 2001.

O Duplo. Trad. de Paulo Bezerra. São Paulo, Ed. 34, 2011.

Le Double. Tradução de Gustave Aucouturier, prefácio de André Green). Paris: Gallimard, 2006.

Goethe, J. W. Tutte le poesie. Trad. de Roberto Fertonani. Milão, Mondadori, 2001.

GóGOL, N. "Noite de Natal”. In: O Capote e outras histórias. Trad. de Paulo Bezerra. São Paulo: Ed. 34, 2011, pp. 105-159.

JAKOBSON, RomAN. A geração que esbanjou seus poetas. São Paulo: Cosac\&Naify, 2006.

Six leçons sur le son et le sens. Paris : Les Éditions de Nuit, 1976.

Russie, folie, poésie. Paris : Éditions du Seuil, 1986.

LIVCHITS, B. L'archer à un oeil et demi. Lausanne : L'Âge d'Homme, 1971.

Lermontov, M. “The Demon". In: Wiggins, G. The Ardis Anthology of Russian Futurism. Michigan: Ardis, 1980.

PASternak, B. Doutor Jivago. Trad. de Zoia Prestes. Rio de Janeiro, São Paulo: Record, 2002.

Pomorska, K. Formalismo e Futurismo. A Teoria Formalista Russa e seu Ambiente Poético. São Paulo: Perspectiva, 2010.

PúchKIn, A. A dama de espadas . Prosa e Poemas. Trad. de Boris Schnaiderman e Nelson Ascher. São Paulo: Ed. 34, 1999.

Renfrew, A., Tihanov, G. (org.) Critical Theory in Russia and the West. London, New York: Routledge, 2011. 
PASTERnAK, B. Seleta em 2 tomos. t. 2. Moscou: Ed. Khudójestvennaya Literatura, 1985.

SChNaIDERman, B. Os escombros e o mito. São Paulo: Companhia das Letras, 1997.

TCHÉKHOV, A. P. "Homem num estojo”. In: A dama do cachorrinho e outros contos. Trad. de B. Schnaiderman. São Paulo: Ed. 34, 2005, pp. 283-298.

Troubetzkoy, Wladimir (org.). La Figure du Double. Coleção "Questions Comparatistes”. Langres: Didier Erudition, 1995.

WILDE, O. The Ballad of Reading Gaol and other poems. Londres: Penguin Classics, 2010.

\section{Obras de referência}

Benedetti, C. (ORG.). Avec Maïakovski. Par Lili Brik. Paris: Editions du Sorbier, 1976.

Bernardini, A. F. "Materiais para o Estudo do Futurismo Russo e do Futurismo Italiano". 1970. 160 f. Dissertação (Mestrado) - FFLCH - Universidade de São Paulo, São Paulo, 1970.

BEYER JR., T. R. 501 Russian Verbs. NY: Barron's, 2008.

CÂNDIDO, A. O estudo analítico do poema. São Paulo: Humanitas, 1996.

CHARTERS, Ann e Samuel. I love. The story of Vladimir Mayakovsky and Lili Brik. Toronto: Mc Graw-Hill Ryerson, 1979.

Chernychevsky, N. What is to be done? Tradução de Michael R. Katz. New York: Cornell University Press, 1989. 
Chociay, R. Teoria do Verso. São Paulo: McGraw-Hill do Brasil, 1974.

Conio, G. L'art contre les masses. Esthétiques et idéologies de la modernité : essais. Lausanne : L'Âge d'Homme, 2003

EIKHENBAUM B. M. ; CONIO, G. Le formalisme et le futurisme russes devant le marxisme : problèmes de la révolution culturelle. Lausanne : L'Âge d'Homme, 1975.

Fernandes, J. A. Dicionário de Rimas da Língua Portuguesa. Rio de Janeiro, São Paulo: Record, 1991.

FRANCISCO JÚNIOR, M. R. “Zanguézi, de Velímir Khlébnikov: a utopia da obra de arte como síntese perfeita do universo". 2007. 307 f. Tese (Doutorado) - FFLCH Universidade de São Paulo, São Paulo, 2007.

FrIOUX, C. Le Chantier Russe. Littérature, société et politique. Tome 1. Écrits 19571968. Paris: L’Harmattan, 2010.

GASPAROV, M. L. Russkie stikhi. 1890-1925 godov v kommentariiakh. Moscou: Vyschaia Chkola, 1993.

KEEFER, L. "The musical imagery of Vladimir Mayakovski". In: American Slavic and East European Review, vol. 5, nº 314 (nov., 1946), pp. 109-120.

MessinA, R. Majakovskij Artista. 1893-1993. Rieti: Biblioteca Paroniana, 1993.

MikHailov, A. Maiakóvski. O poeta da revolução. Rio de Janeiro, São Paulo: Record, 2008.

Polonskaja, V. Il mio Majaikovskij. Firenzi: Passagli editori, 2007.

TCHUKÓVsKI, K. "Vladimir Maiakóvski”. In: Les Futuristes. Lausanne: L’Âge d'Homme, 1976. 
Teles, G. M. Vanguarda Europeia e Modernismo Brasileiro. Petrópolis: Vozes, 1983.

TiniAnOv, I. O problema da linguagem poética. Rio de Janeiro: Tempo Brasileiro, 1975.

TOledo, D. de O. e Filipouski, A. M. R. (ORG.) Teoria da Literatura. Formalistas Russos. São Paulo: Globo, 1978.

Travi, ChiAra (ORG.). Ti bacio uma due tre volte. Elsa Triolet - Vladimir Majakovskij. Lettere 1915 - 1917. Milano: Archinto, 2000.

Trotski, L. Literatura e Revolução. Rio de Janeiro: Jorge Zahar Ed., 2007.

VOINOVA, N.; STARETS, S.; VERKHUCHA, V.; ZDITOVETSKI A. Russko-Portugalskii slovar (Dicionário Russo-Português). Lisboa: Ulmeiro, 1989.

ZolkovskJi, A. K. “Dell'amplificazione”. In: Faccani, R., Eco, U. I sistemi di segni e lo strutturalismo soviético. Milano: Valentino Bompiani, 1969. 
AneXos 
I. Poema integral em russo

ПРО ЭТО

ПРО ЧТО — ПРО ЭТО?

В этой теме,

и личной

и мелкой,

перепетой не раз

и не пять,

я кружил поэтической белкой

и хочу кружиться опять.

Эта тема

сейчас

10

и молитвой у Будды

и у негра вострит на хозяев нож.

Если Марс,

и на нем хоть один сердцелюдый,

то и он

сейчас

скрипит

про то ж.

Эта тема придет,

калеку за локти

20

подтолкнет к бумаге,

прикажет:

- Скреби! -

И калека

с бумаги

срывается в клёкоте, 
только строчками в солнце песня рябит.

Эта тема придет,

позвонйтся с кухни,

повернется,

сгинет шапчонкой гриба,

и гигант

постоит секунду

и рухнет,

под записочной рябью себя погребя.

Эта тема придет,

прикажет:

— Истина! -

Эта тема придет,

велит:

40

$$
\text { — Красота! - }
$$

И пускай

перекладиной кисти раскистены —

только вальс под нос мурлычешь с креста.

Эта тема азбуку тронет разбегом -

уж на что б, казалось, книга ясна! -

и становится

$$
-A-
$$

недоступней Казбека.

Замутит,

оттянет от хлеба и сна.

Эта тема придет,

вовек не износится,

только скажет:

— Отныне гляди на меня! —

И глядишь на нее,

и идешь знаменосцем,

красношелкий огонь над землей знаменя.

Это хитрая тема!

Нырнет под события, 
в тайниках инстинктов готовясь к прыжку,

и как будто ярясь

— посмели забыть eе! -

затрясет;

посыпятся души из шкур.

Эта тема ко мне заявилась гневная,

приказала:

— Подать

дней удила! —

Посмотрела, скривясь, в мое ежедневное

70

и грозой раскидала людей и дела.

Эта тема пришла,

остальные оттерла

и одна

безраздельно стала близка.

Эта тема ножом подступила к горлу.

Молотобоец!

От сердца к вискам.

Эта тема день истемнила, в темень

колотись - велела - строчками лбов.

80

Имя

этой

теме: 


\section{БАЛЛАДА РЕДИНГСКОЙ ТЮРЬМЫ}

Стоял - вспоминаю.

Былл этот блеск.

И это

могда

называлось Невою.

Маяковский, «Человек».

О балладе и о балладахНемолод очень лад баллад, но если слова болят

и слова говорят про то, что болят, молодеет и лад баллад.

Лубянский проезд.

Водопьяный.

90 Вид

вот.

Bот

фон.

В постели она.

Она лежит.

Он.

На столе телефон.

«Он» и «она» баллада моя.

Не страшно нов я.

100 Страшно то,

ч то «он» — это я

и то, что «она»-

моя.

При чем тюрьма?

Рождество.

Кутерьма.

Без решеток окошки домика!

Это вас не касается. 


$$
\text { Говорю - тюрьма. }
$$

Стол.

На столе соломинка.

Тронул еле - волдырь на теле.

Трубку из рук вон.

Из фабричной марки -

две стрелки яркие

омолниили телефон.

Соседняя комната.

Из соседней

сонно:

120

— Когда это?

Откуда это живой поросенок? -

Звонок от ожогов уже визжит, добела раскален аппарат.

Больна она!

Она лежит!

Беги!

Скорей!

Пора!

Мясом дымясь, сжимаю жжение.

Моментально молния телом забегала.

Стиснул миллион вольт напряжения.

Ткнулся губой в телефонное пекло.

Дыры

сверля

в доме,

взмыв

Мясницкую 
пашней,

рвя

140

кабель,

номер

пулей

летел

барышне.

Смотрел осовело барышнин глаз -

под праздник работай за двух.

Красная лампа опять зажглась.

Позвонила!

Огонь потух.

150

И вдруг

как по лампам пошло́ куролесить,

вся сеть телефонная рвется на нити.

$-67-10$ !

Соедините! -

В проулок!

Скорей!

Водопьяному в тишь!

$\mathrm{Yx}$ !

А то с электричеством станется -

160

под Рождество

на воздух взлетишь

со всей

со своей

телефонной

станцией.

Жил на Мясницкой один старожил.

Сто лет после этого жил -

про это лишь -

сто лет! -

170

говаривал детям дед.

— Было - суббота... 
под воскресенье...

Окорочок...

Хочу, чтоб дешево..

Как вдарит кто-то!..

Землетрясенье...

Ноге горячо...

Ходун - подошва!.. -

Не верилось детям,

чтоб так-то

да там-то.

Землетрясенье?

Зимой?

У почтамта?!

По кабелю пущчен номер

Протиснувшись чудом сквозь тоненький шнур,

раструба трубки разинув оправу,

погромом звонков громя тишину,

разверг телефон дребезжащую лаву.

Это визжащее,

190

звенящее это

пальнуло в стены,

старалось взорвать их.

Звоночинки

тыщей

от стен

рикошетом

под стулья закатывались

и под кровати.

Об пол с потолка звоно́чище хлопал.

И снова, 
звенящий мячище точно,

взлетал к потолку, ударившись о́б пол,

и сыпало вниз дребезгою звоночной.

Стекло за стеклом,

вьюшку за вьюшкой

тянуло

звенеть телефонному в тон.

Тряся

ручоночкой

210

дом-погремушку,

тонул в разливе звонков телефон.

Секундантша

От сна

чуть видно -

точка глаз

иголит щеки жаркие.

Ленясь, кухарка поднялась,

идет,

кряхтя и харкая.

Моченым яблоком она.

220

Морщинят мысли лоб ее.

- Кого?

Владим Владимыч?!

$\mathrm{A} !$

Пошла, туфлёю шлепая.

Идет.

Отмеряет шаги секундантом.

Шаги отдаляются...

Слышатся еле...

Весь мир остальной отодвинут куда-то, 
лишь трубкой в меня неизвестное целит.

Застыли докладчики всех заседаний, не могут закончить начатый жест.

Как были,

$$
\begin{aligned}
& \text { рот разинув, } \\
& \text { сюда они }
\end{aligned}
$$

смотрят на Рождество из Рождеств.

Им видима жизнь

от дрязг и до дрязг.

Дом их -

$$
\text { единая будняя тина. }
$$

Будто в себя,

$$
\text { в меня смотрясь, }
$$

ждали

смертельной любви поединок.

Окаменели сиренные рокоты.

Колес и шагов суматоха не вертит.

Лишь поле дуэли

да время-доктор

с бескрайним бинтом исцеляющей смерти.

Москва -

за Москвой поля примолкли.

Моря -

за морями горы стройны.

Вселенная

Вся

как будто в бинокле,

в огромном бинокле (с другой стороны).

Горизонт распрямился 
ровно-ровно.

Тесьма.

Натянут бичевкой тугой.

Край один -

я в моей комнате,

ты в своей комнате - край другой.

А между -

такая,

какая не снится,

какая-то гордая белой обновой,

через вселенную

легла Мясницкая

миниатюрой кости слоновой.

Ясность.

Прозрачнейшей ясностью пытка.

В Мясницкой

деталью искуснейшей выточки

кабель

тонюсенький —

ну, просто нитка!

И всё

вот на этой вот держится ниточке.

Рa3!

Трубку наводят.

Надежду

брось.

Два!

Как раз

остановилась, 
не дрогнув,

между

290

моих

мольбой обволокнутых глаз.

Хочется крикнуть медлительной бабе:

— Чего задаетесь?

Стоите Дантесом.

Скорей,

скорей просверлите сквозь кабель

пулей

любого яда и веса. -

Страшнее пуль -

300

оттуда

сюда вот,

кухаркой оброненное между зевот,

проглоченным кроликом в брюхе удава

по кабелю,

вижу,

слово ползет.

Страшнее слов -

из древнейшей древности,

где самку клыком добывали люди еще,

310

ползло

из шнура -

скребущейся ревности

времен троглодитских тогдашнее чудище.

А может быть...

Наверное, может!

Никто в телефон не лез и не лезет,

нет никакой троглодичьей рожи.

Сам в телефоне.

Зеркалюсь в железе.

320

Возьми и пиши ему ВЦИК циркуляры!

Пойди - эту правильность с Эрфуртской сверь! 
Сквозь первое горе

бессмысленный,

ярый,

мозг поборов,

проскребается зверь.

Что может сделаться с человеком!

Красивый вид.

Товарищи!

Взвесьте!

330

В Париж гастролировать едущий летом,

поэт,

почтенный сотрудник «Известий»,

царапает стул когтём из штиблета.

Вчера человек -

единым махом

клыками свой размедведил вид я!

Косматый.

Шерстью свисает рубаха.

Тоже туда ж!?

340

В телефоны бабахать!?

К своим пошел!

В моря ледовитые!

Размедвеженье

Медведем,

когда он смертельно сердится,

на телефон 
грудь

на врага тяну.

А сердце

глубже уходит в рогатину!

350

Течет.

Ручьища красной меди.

Рычанье и кровь.

Лакай, темнота!

Не знаю,

плачут ли,

нет медведи,

но если плачут,

то именно так.

То именно так:

360

без сочувственной фальши

скулят,

заливаясь ущельной длиной.

И именно так их медвежий Бальшин,

скуленьем разбужен, ворчит за стеной.

Вот так медведи именно могут:

недвижно,

задравши морду,

как те,

повыть,

извыться

и лечь в берлогу,

царапая логово в двадцать когтей.

Сорвался лист.

Обвал.

Беспокоит.

Винтовки-шишки

не грохнули б враз.

Ему лишь взмедведиться может такое

сквозь слезы и шерсть, бахромящую глаз. 
Кровать.

Железки.

Барахло одеяло.

Лежит в железках.

Тихо.

Вяло.

Трепет пришел.

Пошел по железкам.

Простынь постельная треплется плеском.

Вода лизнула холодом ногу.

Откуда вода?

Почему много?

Сам наплакал.

Плакса.

Слякоть.

Неправда -

столько нельзя наплакать.

Чёртова ванна!

Вода за диваном.

Под столом,

за шкафом вода.

С дивана,

сдвинут воды задеваньем,

в окно проплыл чемодан.

Камин...

Окурок...

Сам кинул.

Пойти потушить.

Петушится.

Страх. 
Куда?

К какому такому камину?

Верста.

За верстою берег в кострах.

Размыло всё, даже запах капустный

с кухни

всегдашний,

приторно сладкий.

Река.

Вдали берега.

Как пусто!

Как ветер воет вдогонку с Ладоги!

Река.

Большая река.

Холодина.

Рябит река.

Я в середине.

Белым медведем

взлез на льдину,

плыву на своей подушке-льдине.

Бегут берега,

за видом вид.

Подо мной подушки лед.

С Ладоги дует.

Вода бежит.

Летит подушка-плот.

Плыву.

Лихорадюсь на льдине-подушке.

Одно ощущенье водой не вымыто:

440

я должен

не то под кроватные дужки,

не то

под мостом проплыть под каким-то. 
Были вот так же:

ветер да я.

Эта река!..

Не эта.

Иная.

Нет, не иная!

Было -

стоял.

Было - блестело.

Теперь вспоминаю.

Мысль растет.

Не справлюсь я с нею.

Назад!

Вода не выпустит плот.

Видней и видней...

Ясней и яснее...

460

Теперь неизбежно...

Он будет!

Он вот!!!

Человек из-за 7-ми лет

Волны устои стальные моют.

Недвижный,

страшный,

упершись в бока

столицы,

в отчаяньи созданной мною,

стоит

на своих стоэтажных быках.

Небо воздушными скрепами вышил.

Из вод феерией стали восстал. 
Глаза подымаю выше,

выше...

Вон!

$\mathrm{BoH}-$

опершись о перила моста̀...

Прости, Нева!

Не прощает,

480

гонит.

Сжалься!

Не сжалился бешеный бег.

Он!

$\mathrm{OH}-$

у небес в воспаленном фоне,

прикрученный мною, стоит человек.

Стоит.

Разметал изросшие волосы.

Я уши лаплю.

490

Напрасные мнешь!

Я слышу

мой,

мой собственный голос.

Мне лапы дырявит голоса нож.

Мой собственный голос -

он молит,

он просится:

— Владимир!

Остановись!

Не покинь!

Зачем ты тогда не позволил мне

броситься!

С размаху сердце разбить о быки?

Семь лет я стою.

Я смотрю в эти воды, к перилам прикручен канатами строк. 
Семь лет с меня глаз эти воды не сводят.

Когда ж, когда ж избавления срок?

Ты, может, к ихней примазался касте?

Целуешь?

$$
\text { Ешь? }
$$

Отпускаешь брюшко?

CaM

в ихний быт,

в их семейное счастье

наме́реваешься пролезть петушком?!

Не думай! -

Рука наклоняется вниз его.

Грозится

сухой

в подмостную кручу.

— Не думай бежать!

Это я

вызвал.

Найду.

Загоню.

Доконаю.

Замучу!

530

Taм,

в городе,

праздник.

Я слышу гром его.

Так что ж!

Скажи, чтоб явились они.

Постановленье неси исполкомово.

Му̀ку мою конфискуй,

отмени.

Пока

по этой 
по Невской

по глуби

спаситель-любовь

не придет ко мне,

скитайся ж и ты,

и тебя не полюбят.

Греби!

Тони меж домовьих камней! -

Cnacume!

Стой, подушка!

Напрасное тщенье.

Лапой гребу —

плохое весло.

Мост сжимается.

Невским течением

меня несло,

несло и несло.

Уже я далёко.

Я, может быть, за́ день.

За де́нь

от тени моей с моста.

Но гром его голоса гонится сзади.

В погоне угроз паруса распластал.

- Забыть задумал невский блеск?!

Ее заменишь?!

Некем!

По гроб запомни переплеск,

плескавший в «Человеке». -

Начал кричать.

Разве это осилите?! 
не осилить вовек.

Спасите! Спасите! Спасите! Спасите!

Taм

на мосту

на Неве

человек! 
II

НОЧЬ ПОД РОЖДЕСТВО

Фантастическая реальность

Бегут берега -

за видом вид.

580

Подо мной —

подушка-лед.

Ветром ладожским гребень завит.

Летит

льдышка-плот.

Спасите! - сигналю ракетой слов.

Падаю, качкой добитый.

Речка кончилась -

море росло.

Океан -

590

большой до обиды.

Спасите!

Спасите!..

Сто раз подряд

реву батареей пушечной.

Внизу

подо мной

растет квадрат,

остров растет подушечный.

Замирает, замирает,

600

замирает гул.

Глуше, глуше, глуше...

Никаких морей.

$$
\text { Я - }
$$

на снегу. 


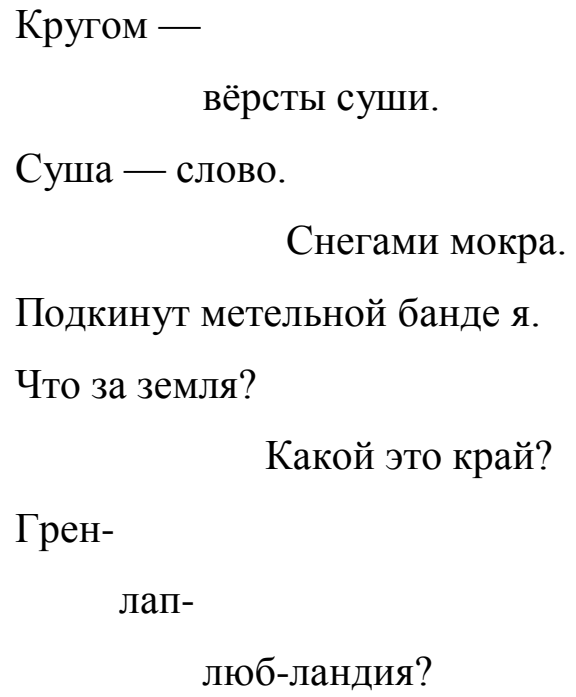

Из облака вызрела лунная дынка, стену постепенно в тени оттеня. Парк Петровский.

Бегу.

\section{Ходынка}

за мной.

Впереди Тверской простыня.

A-y-y-y!

К Садовой аж выкинул «у»!

Оглоблей

или машиной,

но только

мордой

аршин в снегу.

Пулей слова матершины.

630

«От нэпа ослеп?!

Для чего глаза впря́жены?!

Эй, ты!

Мать твою разнэп! 
Ряженый!»

Ax!

Да ведь

я медведь.

Недоразуменье!

$$
\text { Надо - }
$$

640

прохожим,

что я не медведь,

только вышел похожим.

Спаситель

$\mathrm{BoH}$

от заставы

идет человечек.

За шагом шаг вырастает короткий.

Луна

голову вправила в венчик.

Я уговорю,

650

чтоб сейчас же,

чтоб в лодке.

Это - спаситель!

Вид Иисуса.

Спокойный и добрый, венчанный в луне.

Он ближе.

Лицо молодое безусо.

Совсем не Исус.

Нежней.

660

Юней.

Он ближе стал,

он стал комсомольцем. 
Без шапки и шубы.

Обмотки и френч.

То сложит руки,

будто молится.

То машет,

будто на митинге речь.

Вата снег.

Мальчишка шел по вате.

Вата в золоте -

чего уж пошловатей?!

Но такая грусть,

что стой

и грустью ранься!

Расплывайся в процыганенном романсе.

Романс

Мальчик шел, в закат глаза уставя.

Был закат непревзойдимо желт.

Даже снег желтел к Тверской заставе.

680

Ничего не видя, мальчик шел.

Шел,

вдруг

встал.

В шелк

рук

сталь.

С час закат смотрел, глаза уставя,

за мальчишкой легшую кайму.

Снег хрустя разламывал суставы.

690

Для чего?

Зачем? 


\section{Кому?}

Был вором-ветром мальчишка обыскан.

Попала ветру мальчишки записка.

Стал ветер Петровскому парку звонить:

- Прощайте...

Кончаю...

Прошу не винить...

Ничего не поделаешь

До чего ж

на меня похож!

Ужас.

Но надо ж!

Дернулся к луже.

Залитую курточку стягивать стал.

Ну что ж, товарищ!

Тому еще хуже -

семь лет он вот в это же смотрит с моста.

Напялил еле -

другого калибра.

Никак не намылишься -

зубы стучат.

Шерстищу с лапищ и с мордищи выбрил.

Гляделся в льдину...

бритвой луча...

Почти,

почти такой же самый.

Бегу.

Мозги шевелят адресами.

Во-первых,

на Пресню, 
туда,

по задворкам.

Тянет инстинктом семейная норка.

За мной

всероссийские,

теряясь точкой,

сын за сыном,

дочка за дочкой.

Всехные родители

— Володя!

На Рождество!

Вот радость!

Радость-то во!.. -

Прихожая тьма.

Электричество комната.

Сразу -

наискось лица родни.

— Володя!

Господи!

Что это?

В чем это?

Ты в красном весь.

Покажи воротник!

— Не важно, мама,

дома вымою.

Теперь у меня раздолье -

вода.

Не в этом дело.

Родные!

Любимые! 
Ведь вы меня любите?

Любите?

Да?

Так слушайте ж!

Тетя!

Сестры!

Мама!

Тушите елку!

Заприте дом!

Я вас поведу...

вы пойдете...

Мы прямо...

сейчас же...

Bce

возьмем и пойдем.

Не бойтесь -

это совсем недалёко -

600 с небольшим этих крохотных верст.

Мы будем там во мгновение ока.

Он ждет.

Мы вылезем прямо на мост.

— Володя,

родной,

успокойся! -

Но я им

на этот семейственный писк голосков:

— Так что ж?!

Любовь заменяете чаем?

Любовь заменяете штопкой носков? 
Не вы не мама Альсандра Альсеевна.

Вселенная вся семьею засеяна.

Смотрите, мачт корабельных щетина в Германию врезался Одера клин.

Слезайте, мама, уже мы в Штеттине.

Сейчас,

мама, несемся в Берлин.

Сейчас летите, мотором урча, вы: Париж,

Америка,

Бруклинский мост,

Caxapa,

и здесь

с негритоской курчавой лакает семейкой чай негритос.

Сомнете периной

$$
\text { и волю }
$$

800 и камень.

Коммуна -

$$
\text { и то завернется комом. }
$$

Столетия

жили своими домками

и нынче зажили своим домкомом!

Октябрь прогремел,

карающий, судный.

Вы под его огнепёрым крылом расставились, разложили посудины. 
Паучьих волос не расчешешь колом.

Исчезни, дом,

родимое место!

Прощайте! -

Отбросил ступѐней последок.

— Какое тому поможет семейство?!

Любовь цыплячья!

Любвишка наседок!

Бегу и вижу -

всем в виду

кудринскими вышками

себе навстречу

cam

иду

с подарками подмышками.

Мачт крестами на буре распластан,

корабль кидает балласт за балластом.

830

Будь проклята,

опустошенная легкость!

Домами оскалила ска̀лы далекость.

Ни люда, ни заставы нет.

Горят снега,

и го̀ло.

И только из-за ставенек

в огне иголки елок.

Ногам вперекор,

тормозами на быстрые

вставали стены, окнами выстроясь.

По стеклам 
тени

$$
\text { фигурками тира }
$$

вертелись в окне,

зазывали в квартиры.

С Невы не сводит глаз,

$$
\text { продрог, }
$$

стоит и ждет -

$$
\text { помогут. }
$$

За первый встречный за порог закидываю ногу.

В передней пьяный проветривал бредни.

Стрезвел и дернул стремглав из передней.

Зал заливался минуты две:

- Медведь, медведь,

медведь,

медв-е-е-е-е... -

Муж Фекль Давидовны со мной и со всеми знакомыми

Потом,

извертясь вопросительным знаком, хозяин полглаза просунул:

$$
\text { - Однако! }
$$

Маяковский!

$$
\text { Хорош медведь! - }
$$

Пошел хозяин любезностями медоветь:

- Пожалуйста!

Прошу-с.

$$
\text { Ничего - }
$$

Нечаянная радость-с, как сказано у Блока. 
Жена - Фекла Двидна.

Дочка,

точь-в-Точь

в меня, видно -

семнадцать с половиной годочков.

А это...

Вы, кажется, знакомы?! -

Со страха к мышам ушедшие в норы,

из-под кровати полезли партнеры.

880

Усища -

к стеклам ламповым пыльники -

из-под столов пошли собутыльники.

Ползут с-под шкафа чтецы, почитатели.

Весь безлицый парад подсчитать ли?

Идут и идут процессией мирной.

Блестят из бород паутиной квартирной.

Все так и стоит столетья,

как было.

Не бьют -

890

и не тронулась быта кобыла.

Лишь вместо хранителей ду́хов и фей

ангел-хранитель -

жилец в галифе.

Но самое страшное:

по росту,

по коже

одеждой,

сама походка моя! -

в одном

900

узнал -

близнецами похожи -

себя самого -

cam

я. 
С матрацев,

вздымая постельные тряпки,

клопы, приветствуя, подняли лапки.

Весь самовар рассиялся в лучики -

хочет обнять в самоварные ручки.

910 В точках от мух

веночки

с обоев

венчают голову сами собою.

Взыграли туш ангелочки-горнисты, пророзовев из иконного глянца.

Исус,

приподняв

венок тернистый,

любезно кланяется.

920 Маркс,

впряженный в алую рамку,

и то тащил обывательства лямку.

Запели птицы на каждой на жердочке,

герани в ноздри лезут из кадочек.

Как были

сидя сняты

на корточках,

радушно бабушки лезут из карточек.

Раскланялись все,

930

осклабились враз;

кто басом фразу,

кто в дискант

дьячком.

- C праздничком!

С праздничком!

С праздничком!

С праздничком!

С праз- 
нич-

Хозяин

то тронет стул,

то дунет,

сам со скатерти крошки вымел.

- Да я не знал!..

Да я б накануне...

Да, я думаю, занят...

Дом...

Со своими...

Бессмысленные просьбы

950

Мои свои?!

$$
\begin{array}{r}
\text { Д-а-a-a - } \\
\text { это особы. }
\end{array}
$$

Их ведьма разве сыщет на венике!

Мои свои

с Енисея

да с Оби

идут сейчас,

следят четвереньки.

Какой мой дом?!

960

Сейчас с него.

Подушкой-льдом

плыл Невой -

мой дом

меж дамб

стал льдом,

и там..

Я брал слова 
то самые вкрадчивые,

то страшно рыча,

970

то вызвоня лирово.

От выгод -

на вечную славу сворачивал,

молил,

грозил,

просил,

агитировал.

— Ведь это для всех...

для самих...

для вас же...

980

Ну, скажем, «Мистерия»-

ведь не для себя ж?!

Поэт там и прочее...

Ведь каждому важен...

Не только себе ж -

ведь не личная блажь...

Я, скажем, медведь, выражаясь грубо...

Но можно стихи...

Ведь сдирают шкуру?!

Подкладку из рифм поставишь -

990 и шуба!..

Потом у камина...

там кофе...

курят...

Дело пустяшно:

ну, минут на десять...

Но нужно сейчас,

пока не поздно...

Похлопать может...

Сказать -

1000

надейся!..

Но чтоб теперь же... 
чтоб это серьезно... -

Слушали, улыбаясь, именитого скомороха.

Катали по̀ столу хлебные мякиши.

Слова об лоб

$$
\text { и в тарелку - }
$$

горохом.

Один расчувствовался,

вином размягший:

1010

- Поооостой...

поооостой...

Очень даже и просто.

Я пойду!..

Говорят, он ждет...

на мосту...

Я знаю...

Это на углу Кузнецкого мо́ста.

Пустите!

$$
\text { Нукося! - }
$$

1020

По углам -

зуд:

— Наззз-ю-зззюкался!

Будет ныть !

Поесть, попить,

попить, поесть -

и $3 а 66$ !

Теорию к лешему!

Нэп -

практика.

1030

Налей,

нарежь ему.

Футурист,

$$
\text { налягте-ка! - }
$$

Ничуть не смущаясь челюстей целостью, пошли греметь о челюсть челюстью. 
Шли

из артезианских прорв

меж рюмкой

слова поэтических споров.

1040

В матрац,

поздоровавшись,

влезли клопы.

На вещи насела столетняя пыль.

А тот стоит -

в перила вбит.

Он ждет,

он верит:

скоро!

Я снова лбом,

$$
\text { я снова в быт }
$$

вбиваюсь слов напором.

Опять

атакую и вкривь и вкось.

Но странно:

слова проходят насквозь.

Необычайное

Стихает бас в комариные трельки.

Подбитые воздухом, стихли тарелки.

Обои,

стены

1060

блёкли...

блёкли...

Тонули в серых тонах офортовых.

Со стенки

на город разросшийся 
Бёклин

Москвой расставил «Остров мертвых».

Давным-давно.

$$
\text { Подавно - }
$$

теперь.

1070

И нету проще!

BoH

в лодке,

скутан саваном,

недвижный перевозчик.

Не то моря,

$$
\text { не то поля - }
$$

их шорох тишью стерт весь.

А за морями -

тополя

1080

возносят в небо мертвость.

Что ж-

ступлю!

И сразу

тополи

сорвались с мест,

пошли,

затопали.

Тополи стали спокойствия мерами, ночей сторожами, милиционерами.

Расчетверившись,

белый Харон

стал колоннадой почтамтских колонн. 
Так с топором влезают в сон,

обметят спящелобых -

и сразу

исчезает всё,

и видишь только обух.

Так барабаны улиц

1100

B $\mathrm{COH}$

войдут,

и сразу вспомнится,

что вот тоска

и угол вон,

за ним

она -

виновница.

Прикрывши окна ладонью угла,

стекло за стеклом вытягивал с краю.

1110 Вся жизнь

на карты окон легла.

Очко стекла -

и я проиграю.

Арап -

миражей шулер —

по окнам

разметил нагло веселия крап.

Колода стекла

торжеством яркоогним

1120

сияет нагло у ночи из лап.

Как было раньше -

вырасти б,

стихом в окно влететь.

Нет,

никни к сте́нной сырости.

И стих

и дни не те. 
Морозят камни.

$$
\text { Дрожь могил. }
$$

1130

И редко ходят веники.

Плевками,

снявши башмаки,

вступаю на ступеньки.

Не молкнет в сердце боль никак,

кует к звену звено.

Вот так,

$$
\text { убив, }
$$

Раскольников

пришел звенеть в звонок.

1140

Гостьё идет по лестнице...

Ступеньки бросил -

стенкою.

Стараюсь в стенку вплесниться,

и слышу -

струны тенькают.

Быть может, села

вот так

невзначай она.

Лишь для гостей,

1150

для широких масс.

А пальцы

сами

в пределе отчаянья

ведут бесшабашье, над горем глумясь.

Друзья

А во́роны гости?!

Дверье крыло 
раз сто по бокам коридора исхлопано.

Горлань горланья,

\section{оранья орло́}

1160

ко мне доплеталось пьяное до́пьяна.

Полоса

щели.

Голоса́

еле:

«Аннушка -

ну и румянушка!»

Пироги...

Печка...

Шубу...

Помогает...

$$
\text { С плечика... }
$$

Сглушило слова уанстепным темпом, и снова слова сквозь темп уанстепа: «Что это вы так развеселились?

Разве?!»

$$
\text { Сли́лись... }
$$

Опять полоса осветила фразу.

Слова непонятны -

$$
\text { особенно сразу. }
$$

1180

Слова так

$$
\text { (не то чтоб со зла): }
$$

«Один тут сломал ногу,

так вот веселимся, чем бог послал,

танцуем себе понемногу».

Да,

их голоса́.

Знакомые выкрики.

Застыл в узнаваньи,

расплющился, нем,

фразы крою́ по выкриков выкройке. 


$$
\text { Да - }
$$

Шелест.

Листают, наверное, ноты.

«Ногу, говорите?

$$
\text { Вот смешно-то!» }
$$

И снова

в тостах стаканы исчоканы,

и сыплют стеклянные искры из щек они.

И снова

пьяное:

«Ну и интересно!

Так, говорите, пополам и треснул?»

«Должен огорчить вас, как ни грустно, не треснул, говорят,

а только хрустнул».

И снова

хлопанье двери и карканье,

и снова танцы, полами исшарканные.

И снова

стен раскаленные степи

под ухом звенят и вздыхают в тустепе.

Стою у стенки.

$$
\text { Я не я. }
$$

Пусть бредом жизнь смололась.

Но только б, только б не ея

невыносимый голос!

Я день, 
я сам задыхался от этого бреда.

$\mathrm{OH}$

жизнь дымком квартирошным выел.

Звал:

решись

с этажей

в мостовые!

Я бегал от зова разинутых окон,

любя убегал.

1230

Пускай однобоко,

пусть лишь стихом,

лишь шагами ночными -

строчишь,

и становятся души строчными,

и любишь стихом,

а в прозе немею.

Ну вот, не могу сказать,

не умею.

Но где, любимая,

где, моя милая,

где

— в песне! -

любви моей изменил я?

Здесь

каждый звук,

чтоб признаться,

чтоб кликнуть.

А только из песни - ни слова не выкинуть.

Вбегу на трель,

1250

на гаммы.

В упор глазами

в цель!

Гордясь двумя ногами, 
Ни с места! — крикну. -

$$
\text { Цел! - }
$$

Скажу:

- Смотри,

даже здесь, дорогая,

стихами громя обыденщины жуть,

имя любимое оберегая,

тебя

в проклятьях моих

обхожу.

Приди,

разотзовись на стих.

Я, всех оббегав, — тут.

Теперь лишь ты могла б спасти.

Вставай!

Бежим к мосту! -

1270

Быком на бойне

под удар

башку мою нагнул.

Сборю себя,

пойду туда.

Секунда -

и шагну.

Последняя самая эта секунда,

секунда эта

стала началом,

1280

началом

невероятного гуда.

Весь север гудел. 
Гудения мало.

По дрожи воздушной,

по колебанью

догадываюсь -

оно над Любанью.

По холоду,

по хлопанью дверью

догадываюсь -

оно над Тверью.

По шуму —

настежь окна раскинул -

догадываюсь -

кинулся к Клину.

Теперь грозой Разумовское за́лил.

На Николаевском теперь

на вокзале.

Всего дыхание одно,

а под ногой

ступени

пошли,

поплыли ходуном,

вздымаясь в невской пене.

Ужас дошел.

В мозгу уже весь.

Натягивая нервов строй,

разгуживаясь всё и разгуживаясь,

взорвался,

пригвоздил:

- Стой!

Я пришел из-за семи лет,

из-за верст шести ста,

пришел приказать:

Нет!

Пришел повелеть: 


\section{Оставь!}

Оставь!

Не надо

1320

ни слова,

ни просьбы.

Что толку —

тебе

одному

удалось бы?!

Жду,

чтоб землей обезлюбленной

вместе,

чтоб всей

1330

мировой

человечьей гущей.

Семь лет стою,

буду и двести

стоять пригвожденный,

этого ждущий.

У лет на мосту

на презренье,

на сме́х,

земной любви искупителем значась,

1340

должен стоять,

стою за всех,

за всех расплачу́сь,

за всех распла́чусь. -

Ротонда

Стены в тустепе ломались

на́ три, 
на четверть тона ломались,

на сто́...

Я, стариком,

на каком-то Монмартре

1350

лезу -

стотысячный случай -

на стол.

Давно посетителям осточертело.

Знают заранее

всё, как по нотам:

буду звать

(новое дело!)

куда-то идти,

спасать кого-то.

1360

В извинение пьяной нагрузки

хозяин гостям объясняет:

— Русский! —

Женщины -

мяса и тряпок вяза́нки -

смеются,

стащить стараются

за́ ноги:

«Не пойдем.

Дудки!

1370

Мы - проститутки».

Быть Сены полосе б Невой!

Грядущих лет брызго́й

хожу по мгле по Се́новой

всей нынчести изгой.

Саже́нный,

обсмеянный,

са́женный,

битый,

в бульварах 
— Под красное знамя!

Шагайте!

По быту!

Сквозь мозг мужчины!

Сквозь сердце женщины! -

Сегодня

гнали

в особенном раже.

Ну и жара же!

Надо

немного обветрить лоб.

Пойду,

пойду, куда ни вело б.

Внизу свистят сержанты-трельщики.

Тело

с панели

уносят метельщики.

Рассвет.

Подымаюсь сенскою сенью, синематографской серой тенью.

Bot -

гимназистом смотрел их

мелькают сбоку Франции карты.

Воспоминаний последним током тащился прощаться

к странам Востока. 
С разлету рванулся -

и стал,

и на́ мель.

Лохмотья мои зацепились штанами.

Ощупал -

скользко,

луковка точно.

Большое очень.

Испозолочено.

Под луковкой

колоколов завыванье.

Вечер зубцы стенные выкаймил.

1420

На Иване я

Великом.

Вышки кремлевские пиками.

Московские окна

видятся еле.

Весело.

Елками зарождествели.

В ущелья кремлёвы волна ударяла:

то песня,

то звона рождественский вал.

1430

С семи холмов,

низвергаясь Дарьялом,

бросала Тереком

праздник

Москва.

Вздымается волос.

Лягушкою тужусь.

Боюсь - 
оступлюсь на одну только пядь,

и ЭТот

1440

старый

рождественский ужас

меня

по Мясницкой закружит опять.

Повторение пройденного

Руки крестом,

крестом

на вершине,

ловлю равновесие,

страшно машу.

Густеет ночь,

не вижу в аршине.

Луна.

Подо мною

льдистый Машук.

Никак не справлюсь с моим равновесием, как будто с Вербы -

руками картонными.

Заметят.

Отсюда виден весь я.

Смотрите -

Кавказ кишит Пинкертонами.

Заметили.

Всем сообщили сигналом.

Любимых,

друзей

человечьи ленты

со всей вселенной сигналом согнало. 
Спешат рассчитаться,

идут дуэлянты.

Щетинясь,

1470

щерясь

еще и еще там...

Плюют на ладони.

Ладонями сочными,

руками,

ветром,

нещадно,

без счета

в мочалку щеку истрепали пощечинами.

Пассажи -

1480

перчаточных лавок початки,

дамы,

духи развевая паточные,

снимали,

в лицо швыряли перчатки,

швырялись в лицо магазины перчаточные.

Газеты,

журналы,

зря не глазейте!

На помощь летящим в морду вещам

1490 ругней

за газетиной взвейся газетина.

Слухом в ухо!

Хватай, клевеща!

И так я калека в любовном боленьи.

Для ваших оставьте помоев ушат.

Я вам не мешаю.

К чему оскорбленья!

Я только стих,

я только душа.

А снизу: 
- Нет!

Ты враг наш столетний.

Один уж такой попался -

$$
\text { гусар! }
$$

Понюхай порох,

свинец пистолетный.

Рубаху враспашку!

Не празднуй труса́! -

Последняя смерть

Хлеще ливня,

грома бодрей,

Бровь к брови,

ровненько,

со всех винтовок,

со всех батарей,

с каждого маузера и браунинга,

с сотни шагов,

с десяти,

с двух,

в упор -

1520

за зарядом заряд.

Станут, чтоб перевесть дух,

и снова свинцом сорят.

Конец ему!

В сердце свинец!

Чтоб не было даже дрожи!

В конце концов -

всему конец.

Дрожи конец тоже. 
Окончилась бойня.

Веселье клокочет.

Смакуя детали, разлезлись шажком.

Лишь на Кремле

поэтовы клочья

сияли по ветру красным флажком.

Да небо

попрежнему

лирикой зве́здится.

Глядит

в удивленьи небесная звездь -

1540 затрубадури́ла Большая Медведица.

Зачем?

В королевы поэтов пролезть?

Большая,

неси по векам-Араратам

сквозь небо потопа

ковчегом-ковшом!

С борта

звездолётом

медведьинским братом

горланю стихи мирозданию в шум.

Скоро!

Скоро!

Скоро!

В пространство!

Пристальней!

Солнце блестит горы.

Дни улыбаются с пристани. 
ПРОШЕНИЕ НА ИМЯ......

ПРОШУ ВАС, ТОВАРИЩ ХИМИК, ЗАПОЛНИТЕ САМИ!

Пристает ковчег.

1560

Сюда лучами!

Прйстань.

Эй!

Кидай канат ко мне!

И сейчас же

ощутил плечами

тяжесть подоконничьих камней.

Солнце

ночь потопа высушило жаром.

У окна

1570

в жару встречаю день я.

Только с глобуса — гора Килиманджаро.

Только с карты африканской - Кения.

Голой головою глобус.

Я над глобусом

от горя горблюсь.

Мир

хотел бы

$$
\text { в этой груде го́ря }
$$

настоящие облапить груди-горы.

Чтобы с полюсов

по всем жильям

лаву раскатил, горящ и каменист,

так хотел бы разрыдаться я,

медведь-коммунист.

Столбовой отец мой

дворянин,

кожа на моих руках тонка. 
Может,

я стихами выхлебаю дни,

1590

и не увидав токарного станка.

Но дыханием моим,

сердцебиеньем,

голосом,

каждым острием издыбленного в ужас

волоса

дырами ноздрей,

гвоздями глаз,

зубом, исскрежещенным в звериный лязг,

ёжью кожи,

гнева брови сборами,

триллионом пор,

дословно -

всеми порами

в осень,

в зиму,

в весну,

в лето,

в день,

B $\mathrm{COH}$

1610 не приемлю,

ненавижу это всё.

Bcë,

чTо в нас

ушедшим рабьим вбито,

вcё,

что мелочи́нным роем

оседало

и осело бытом

даже в нашем

краснофлагом строе.

Я не доставлю радости 
видеть,

что сам от заряда стих.

За мной не скоро потянете

об упокой его душу таланте.

Меня

из-за угла

ножом можно.

Дантесам в мой не целить лоб.

1630

Четырежды состарюсь - четырежды омоложенный, до гроба добраться чтоб.

Где б ни умер,

умру поя.

В какой трущобе ни лягу,

знаю -

достоин лежать я

с легшими под красным флагом.

Но за что ни лечь -

смерть есть смерть.

1640 Страшно - не любить,

ужас — не сметь.

За всех - пуля,

за всех - нож.

А мне когда?

А мне-то что ж?

В детстве, может,

на самом дне,

десять найду

сносных дней.

1650

А то, что другим?!

Для меня б этого!

Этого нет.

$$
\begin{array}{r}
\text { Видите - } \\
\text { нет его! }
\end{array}
$$

Верить бы в загробь! 
Легко прогулку пробную.

Стоит

только руку протянуть -

пуля

1660

мигом

в жизнь загробную

начерти́т гремящий путь.

Что мне делать,

если я

вовсю,

всей сердечной мерою,

в жизнь сию,

сей

мир

1670

верил,

верую.

Bepa

Пусть во что хотите жданья удлинятся -

вижу ясно,

ясно до галлюцинаций.

До того,

что кажется -

вот только с этой рифмой развяжись,

и вбежишь

по строчке

1680

в изумительную жизнь.

Мне ли спрашивать -

да эта ли?

Да та ли?!

Вижу, 
вижу ясно, до деталей.

Воздух в воздух,

будто камень в камень,

недоступная для тленов и крошений,

рассиявшись,

1690

высится веками

мастерская человечьих воскрешений.

Вот он,

большелобый

тихий химик,

перед опытом наморщил лоб.

Книга -

«Вся земля», -

выискивает имя.

Век двадцатый.

1700

Воскресить кого б?

— Маяковский вот...

Поищем ярче лица -

недостаточно поэт красив. -

Крикну я

вот с этой,

с нынешней страницы:

— Не листай страницы!

Воскреси!

Надежда

Сердце мне вложи!

1710

Крови́щу —

до последних жил

В череп мысль вдолби!

Я свое, земное, не дожѝл, 
на земле

свое не долюбил.

Был я сажень ростом.

А на что мне сажень?

Для таких работ годна и тля.

Перышком скрипел я, в комнатенку всажен,

вплющился очками в комнатный футляр.

Что хотите, буду делать даром -

чистить,

мыть,

стеречь,

мотаться,

месть.

Я могу служить у вас

хотя б швейцаром.

Швейцары у вас есть?

1730

Был я весел -

толк веселым есть ли,

если горе наше непролазно?

Нынче

обнажают зубы если,

только, чтоб хватить,

чтоб лязгнуть.

Мало ль что бывает -

тяжесть

или горе...

Позовите!

Пригодится шутка дурья.

Я шарадами гипербол,

аллегорий

буду развлекать,

стихами балагуря

Я любил...

Не стоит в старом рыться. 
Больно?

Пусть...

1750

Живешь и болью дорожась.

Я зверье еще люблю -

у вас

зверинцы

есть?

Пустите к зверю в сторожа.

Я люблю зверье.

Увидишь собачонку -

тут у булочной одна -

сплошная плешь, -

1760

из себя

и то готов достать печенку.

Мне не жалко, дорогая,

ешь!

Любовь

Может,

может быть,

когда-нибудь

дорожкой зоологических аллей

и она -

она зверей любила -

1770

тоже ступит в сад,

улыбаясь,

вот такая,

как на карточке в столе.

Она красивая -

ее, наверно, воскресят.

Ваш 
тридцатый век

обгонит стаи

сердце раздиравших мелочей.

1780

Нынче недолюбленное

наверстаем

звездностью бесчисленных ночей.

Воскреси

хотя б за то,

что Я

поэтом

ждал тебя,

откинул будничную чушь!

Воскреси меня

1790

хотя б за это!

Воскреси -

свое дожить хочу!

Чтоб не было любви - служанки

замужеств,

похоти,

хлебов.

Постели прокляв,

встав с лежанки,

чтоб всей вселенной шла любовь.

1800

Чтоб день,

который горем старящ,

не христарадничать, моля.

Чтоб вся

на первый крик:

— Товарищ! —

оборачивалась земля.

Чтоб жить

не в жертву дома дырам.

Чтоб мог

в родне 
отныне

стать

отец

по крайней мере миром,

землей по крайней мере - мать. 
II. Tabela de Transliteração do Russo para o Português.

\begin{tabular}{|c|c|c|}
\hline Alabeto Russo & $\begin{array}{c}\text { Transcrição para registro } \\
\text { Catalográfico ou Linguístico }\end{array}$ & $\begin{array}{c}\text { Adaptação Fonética para } \\
\text { Nomes Próprios }\end{array}$ \\
\hline A & A & A \\
\hline Б & B & B \\
\hline B & $\mathrm{V}$ & V \\
\hline$\Gamma$ & G & $\mathrm{G}, \mathrm{Gu}$ antes de $e, i$ \\
\hline Д & $\mathrm{D}$ & $\mathrm{D}$ \\
\hline $\mathrm{E}$ & $\mathrm{E}$ & E, Ié \\
\hline$\ddot{\mathrm{E}}$ & Io & Io \\
\hline Ж & $\mathrm{J}$ & $\mathrm{J}$ \\
\hline 3 & $\mathrm{Z}$ & $\mathrm{Z}$ \\
\hline И & $\mathrm{I}$ & $\mathrm{I}$ \\
\hline Й & I & I \\
\hline K & $\mathrm{K}$ & $\mathrm{K}$ \\
\hline Л & $\mathrm{L}$ & $\mathrm{L}$ \\
\hline $\mathrm{M}$ & $\mathrm{M}$ & M \\
\hline $\mathrm{H}$ & $\mathrm{N}$ & $\mathrm{N}$ \\
\hline $\mathrm{O}$ & $\mathrm{O}$ & $\mathrm{O}$ \\
\hline$\Pi$ & $\mathrm{P}$ & $\mathrm{P}$ \\
\hline $\mathrm{P}$ & $\mathrm{R}$ & $\mathrm{R}$ \\
\hline $\mathrm{C}$ & $S$ & S, SS (intervocálico) \\
\hline $\mathrm{T}$ & $\mathrm{T}$ & $\mathrm{T}$ \\
\hline $\mathrm{y}$ & $\mathrm{U}$ & $\mathrm{U}$ \\
\hline$\Phi$ & $\mathrm{F}$ & $\mathrm{F}$ \\
\hline $\mathrm{X}$ & $\mathrm{Kh}$ & $\mathrm{Kh}$ \\
\hline Ц & Ts & Ts \\
\hline Ч & Tch & Tch \\
\hline Ш & $\mathrm{Ch}$ & $\mathrm{Ch}$ \\
\hline Щ & Chtch & Chtch \\
\hline $\mathrm{b}$ & $"$ & \\
\hline Ы & $\mathrm{Y}$ & $\mathrm{Y}$ \\
\hline $\mathrm{b}$ & , & \\
\hline Э & É & É \\
\hline Ю & $\mathrm{Iu}$ & $\mathrm{Iu}$ \\
\hline Я & Ia & Ia \\
\hline
\end{tabular}

Fonte: Caderno de Cultura e Literatura Russa, n. 1, São Paulo, março de 2004. 
III. Capa e folha de rosto da primeira edição de Sobre Isto, publicada em junho de 1923. Fotomontagem de A. Ródtchenko.
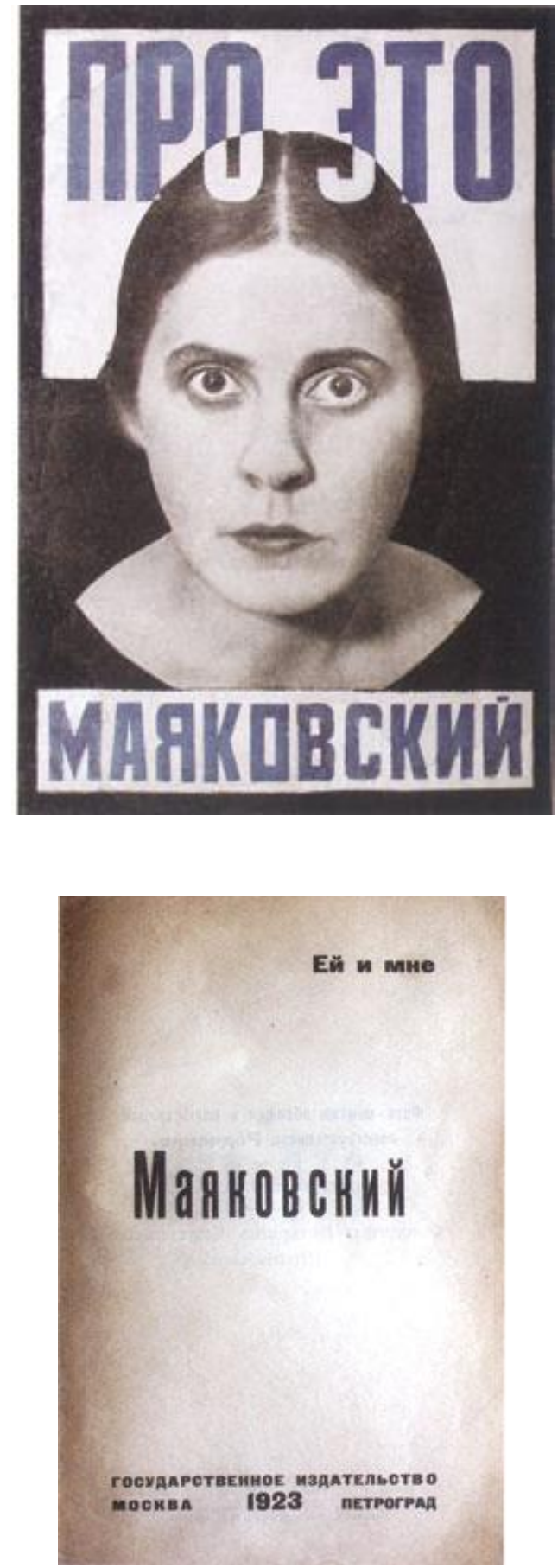

Fonte: http://compuart.ru/article.aspx?id=22162\&iid=1014, acesso em 28 de dezembro de 2014. 
IV. Lília Brik segurando um exemplar de Sobre Isto. Foto de A. Ródtchenko, 1924.

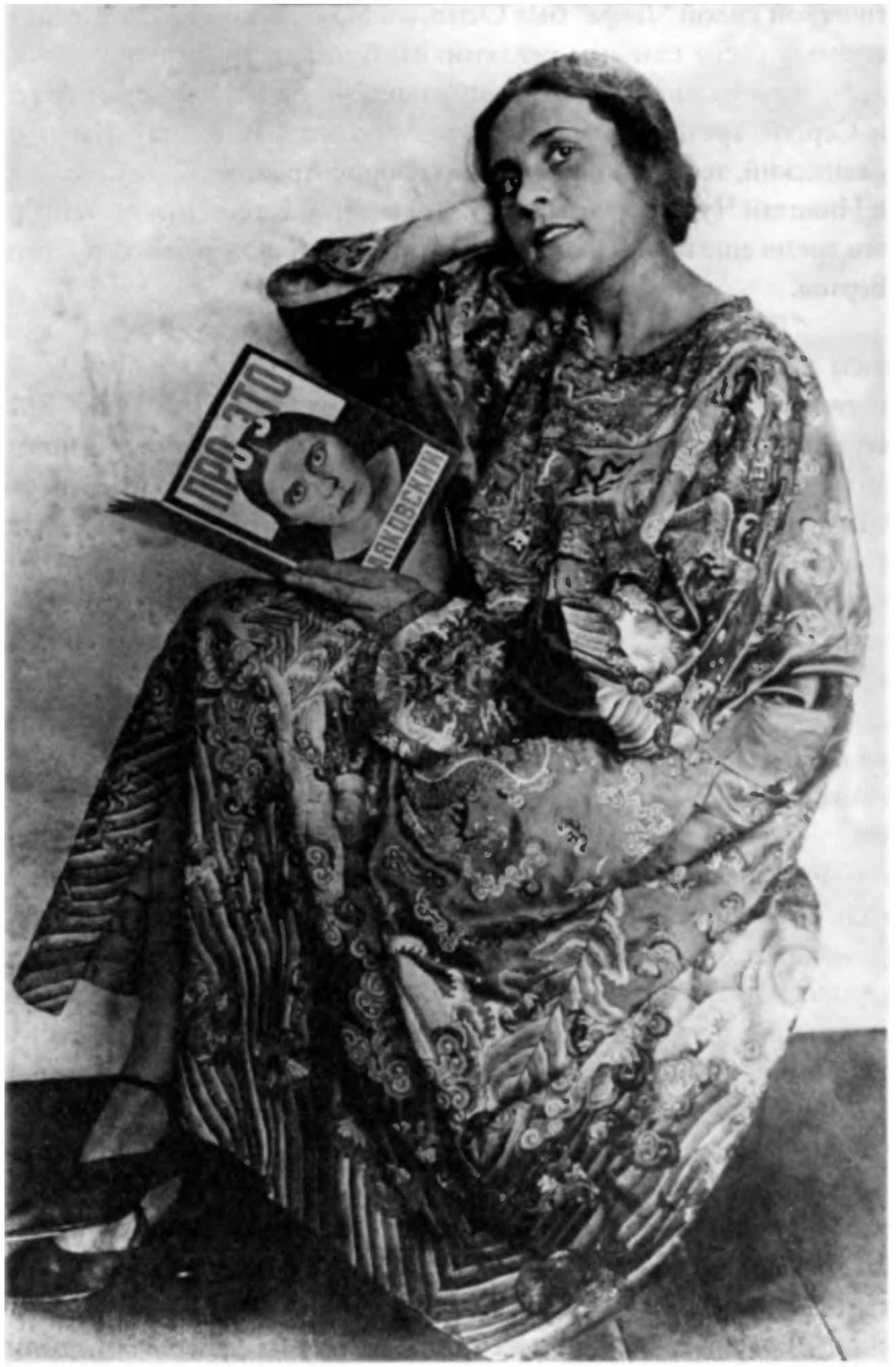

Fonte: http://coollib.com/b/166980/read, acesso em 28 de dezembro de 2014. 
V. Fotomontagens de A. Ródtchenko para a primeira edição de Sobre Isto. Fotos de Avraam Sterenberg.

\section{Fotomontagem 1:}

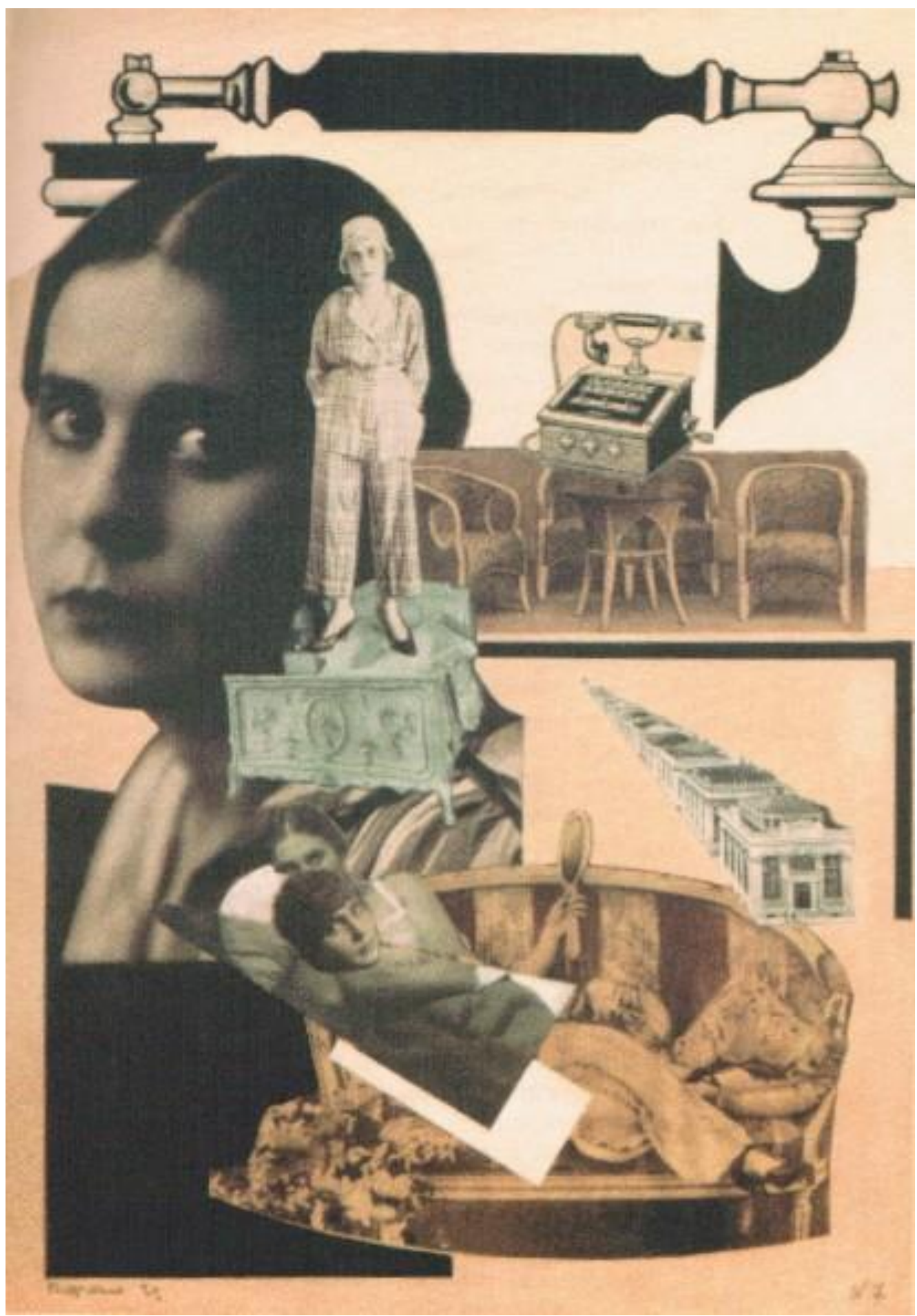

В постели она./ Она лежит./Он. / На столе телефон.

Na cama ela. / Ela está deitada. / Ele. / Na mesa o telefone. 


\section{Fotomontagem 2 :}

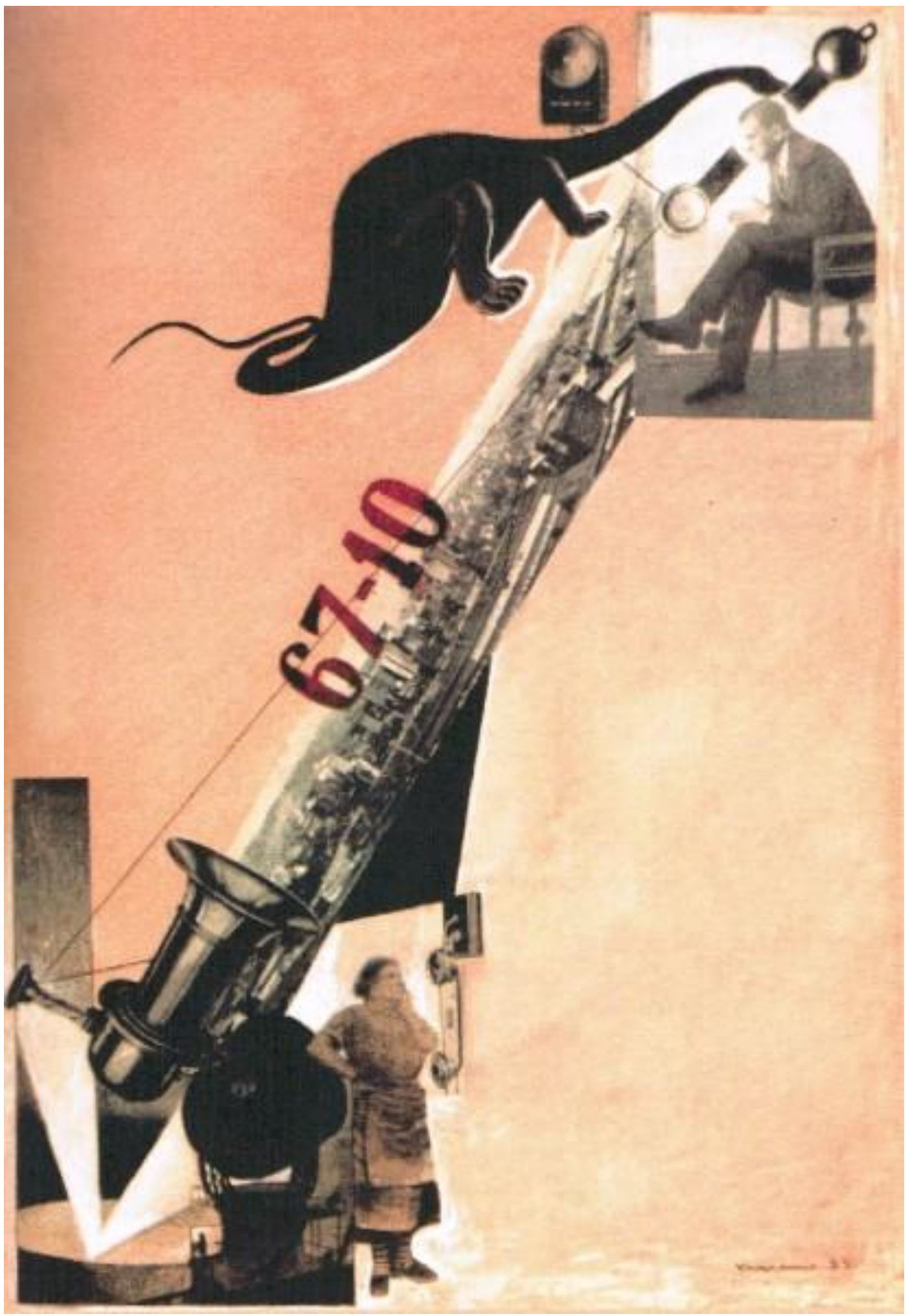

...ползло из шнура - скребущейся ревности / времен троглодитских тогдашнее чудище. ...arrasta-se do fio - o ciúme escorchador, / monstro do tempo troglodita de outrora. 


\section{Fotomontagem 3 :}

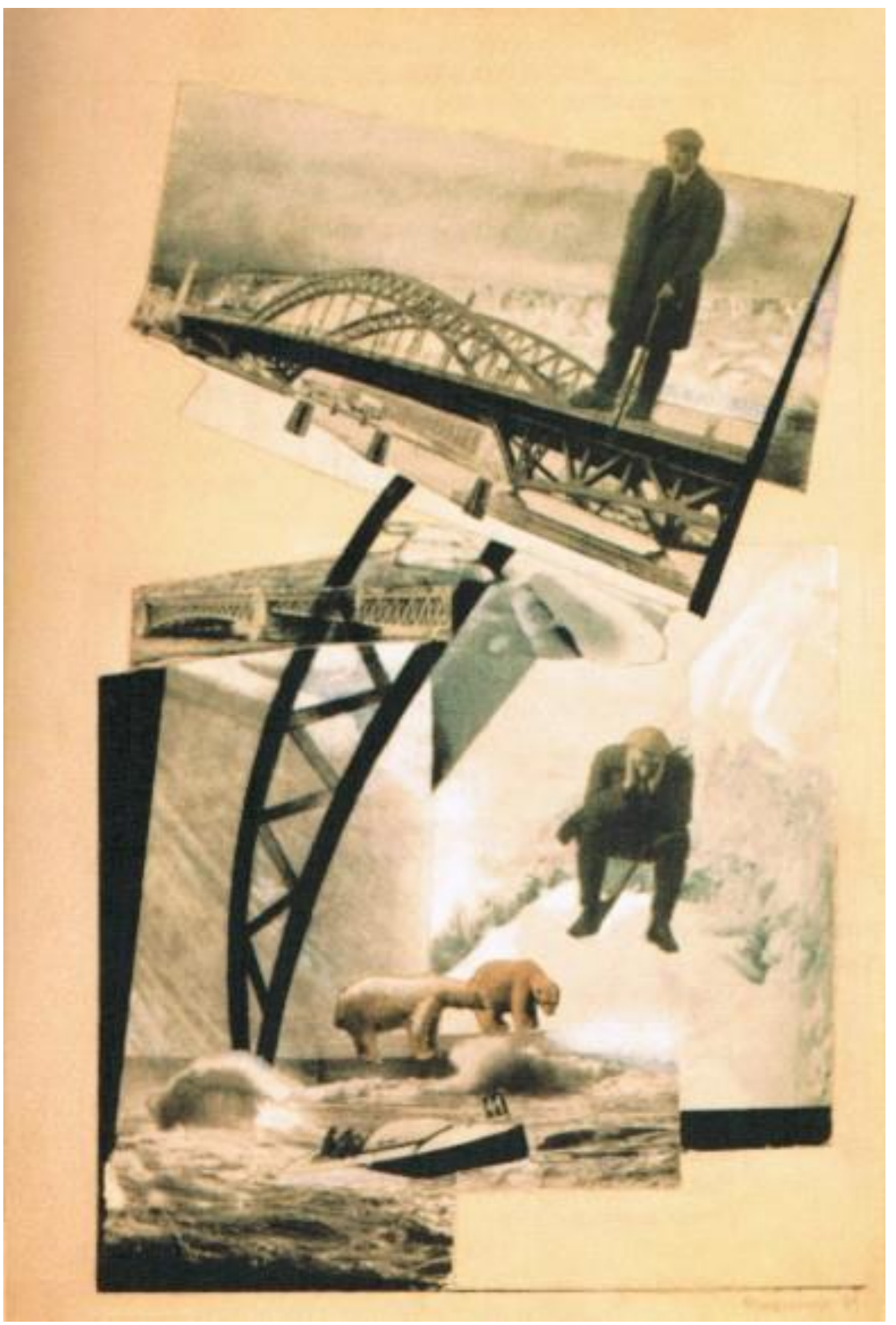

Я уши лаплю. Напрасные мнешь!/ Я слышу мой, мой собственный голос./ Мне лапы дырявит голоса нож.

Pateio as orelhas. Tão inúteis ! / Eu ouço a minha, a minha própria voz. / A lâmina da voz trespassa as minhas patas. 


\section{Fotomontagem 4 :}

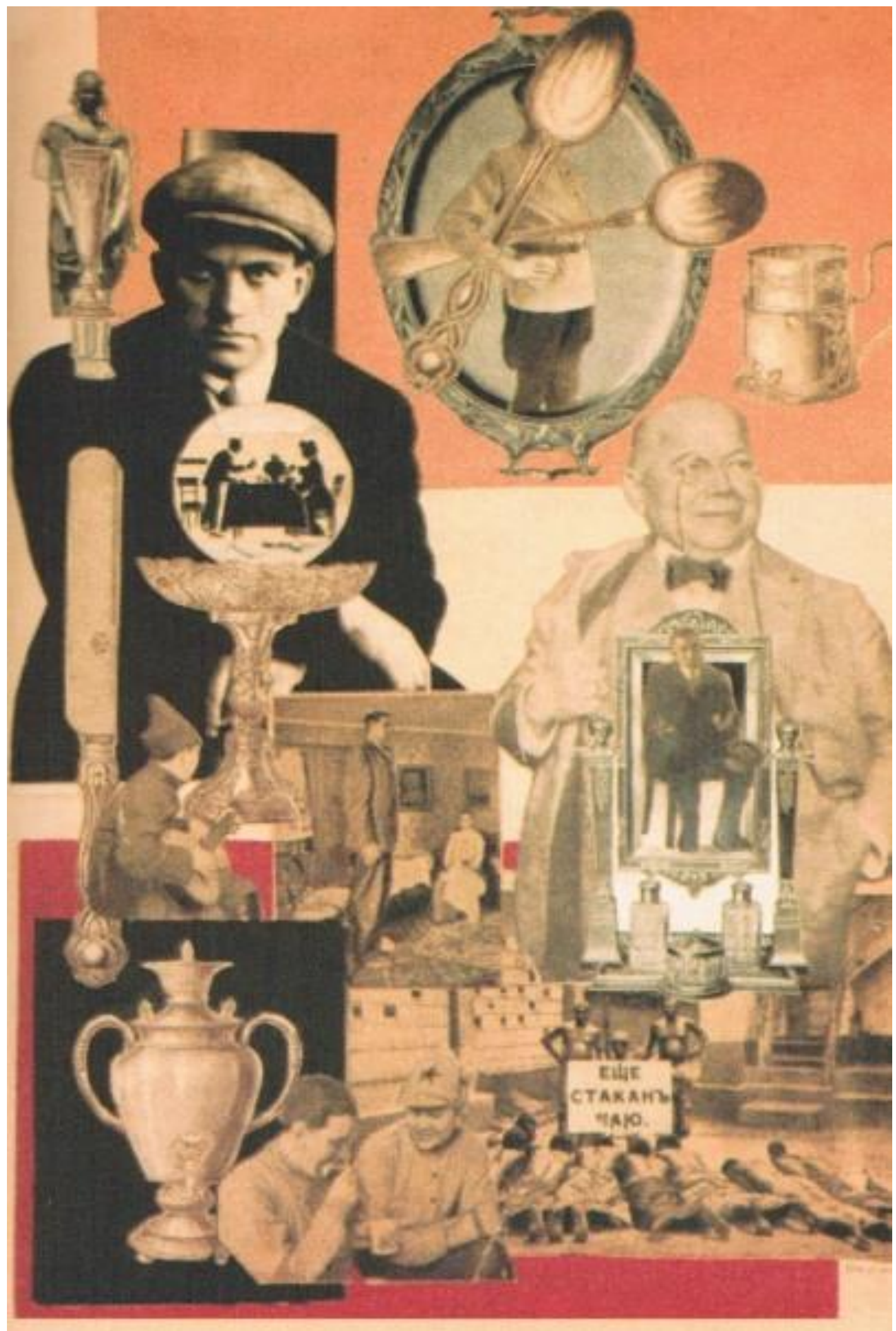

Все так и стоит столетья, как было./Не бьют - и не тронулась быта кобыла.

Tudo exatamente igual, secular. / Sem o chicote - a égua da vida não se move. 


\section{Fotomontagem 5 :}

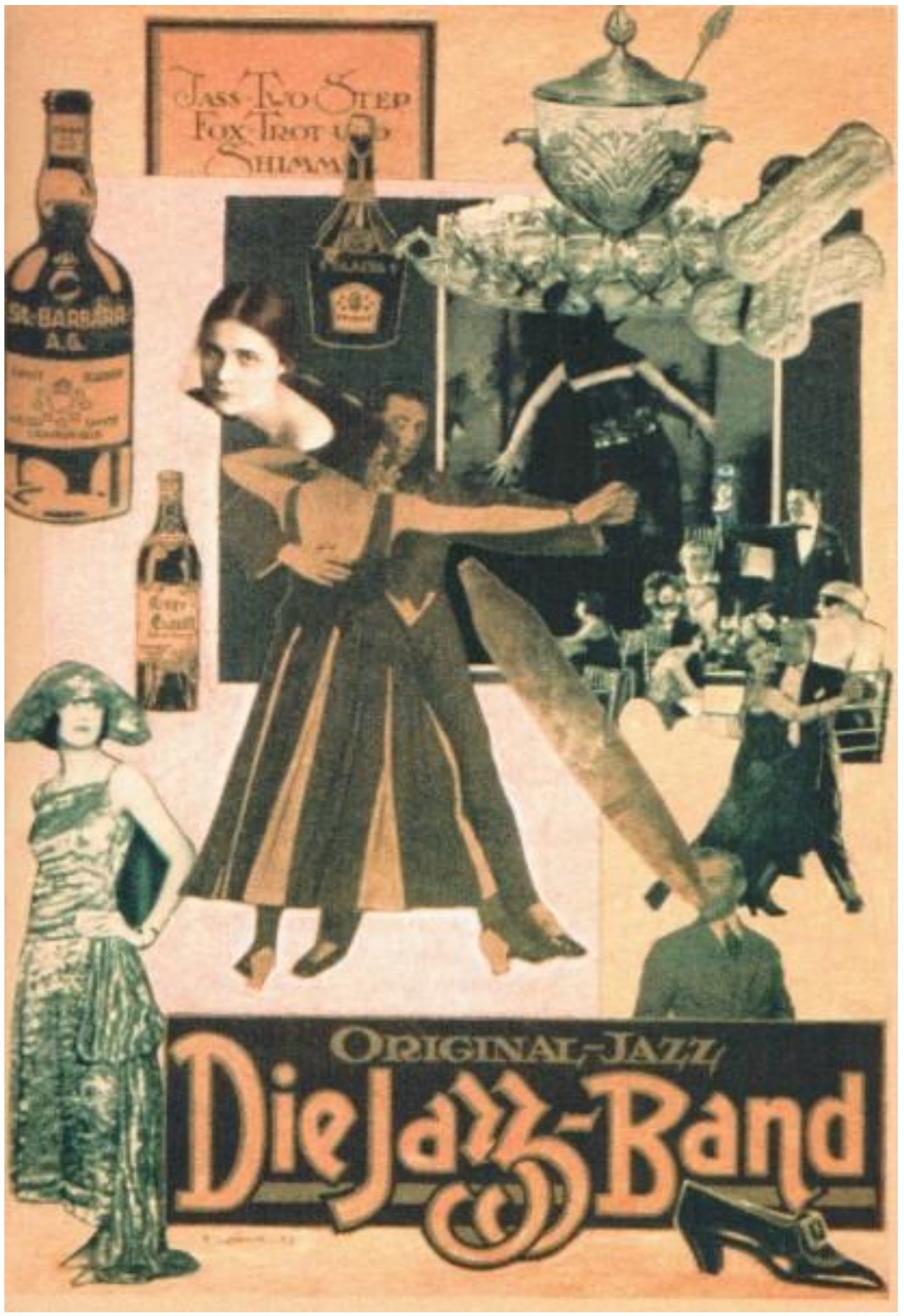

И снова стен раскаленные степи /под ухом звенят и вздыхают в тустепе.

E novamente ardendo em brasas nas paredes, as estepes / ressoam e suspiram no two-step. 


\section{Fotomontagem 6 :}

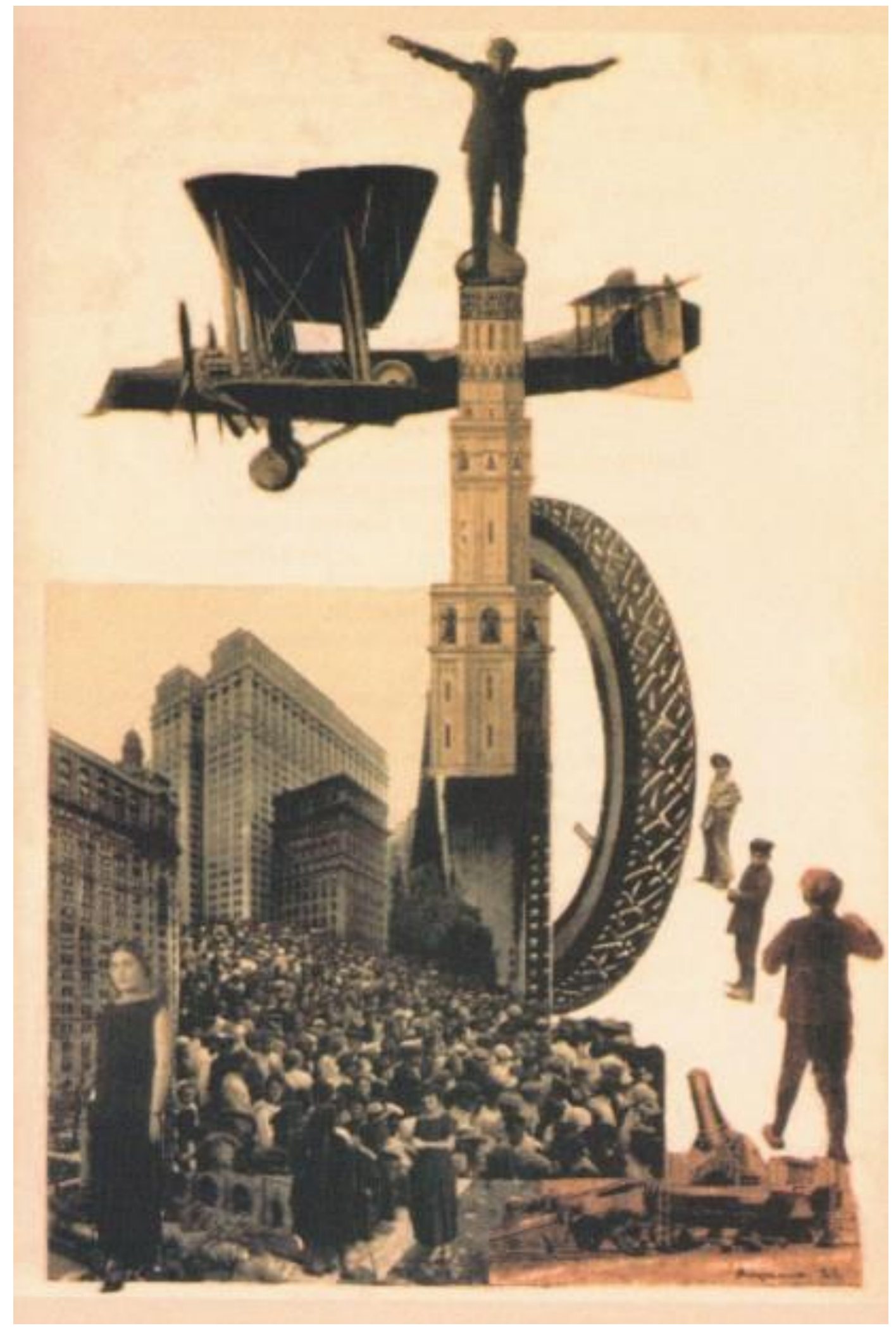

... ловлю равновесие, страшно машу.

... tento me equilibrar, terríveis gestos. 


\section{Fotomontagem 7 :}

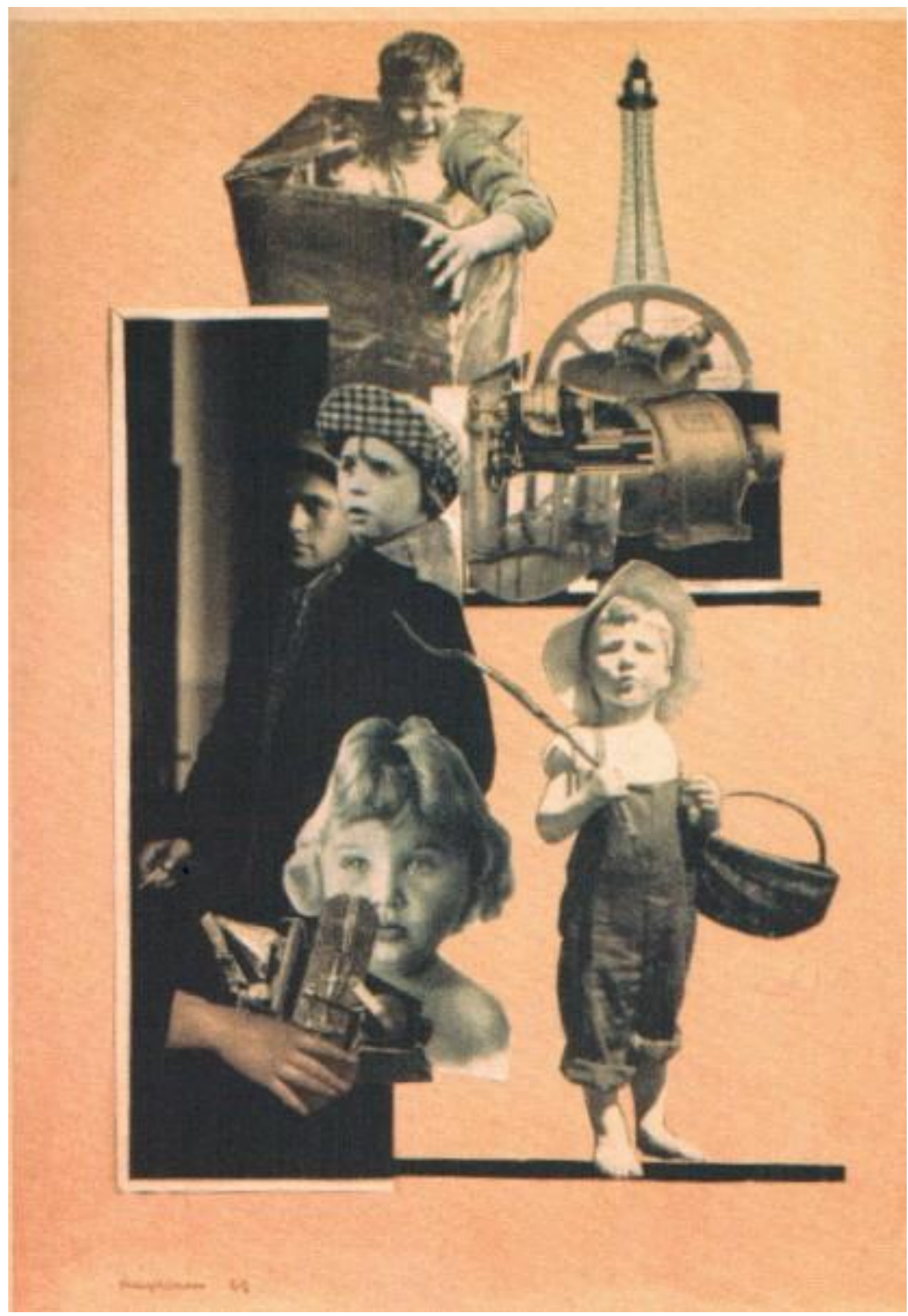

Четырежды состарюсь - четырежды омоложенный...

Quatro vezes envelheço - quatro vezes rejuveneço... 


\section{Fotomontagem 8 :}

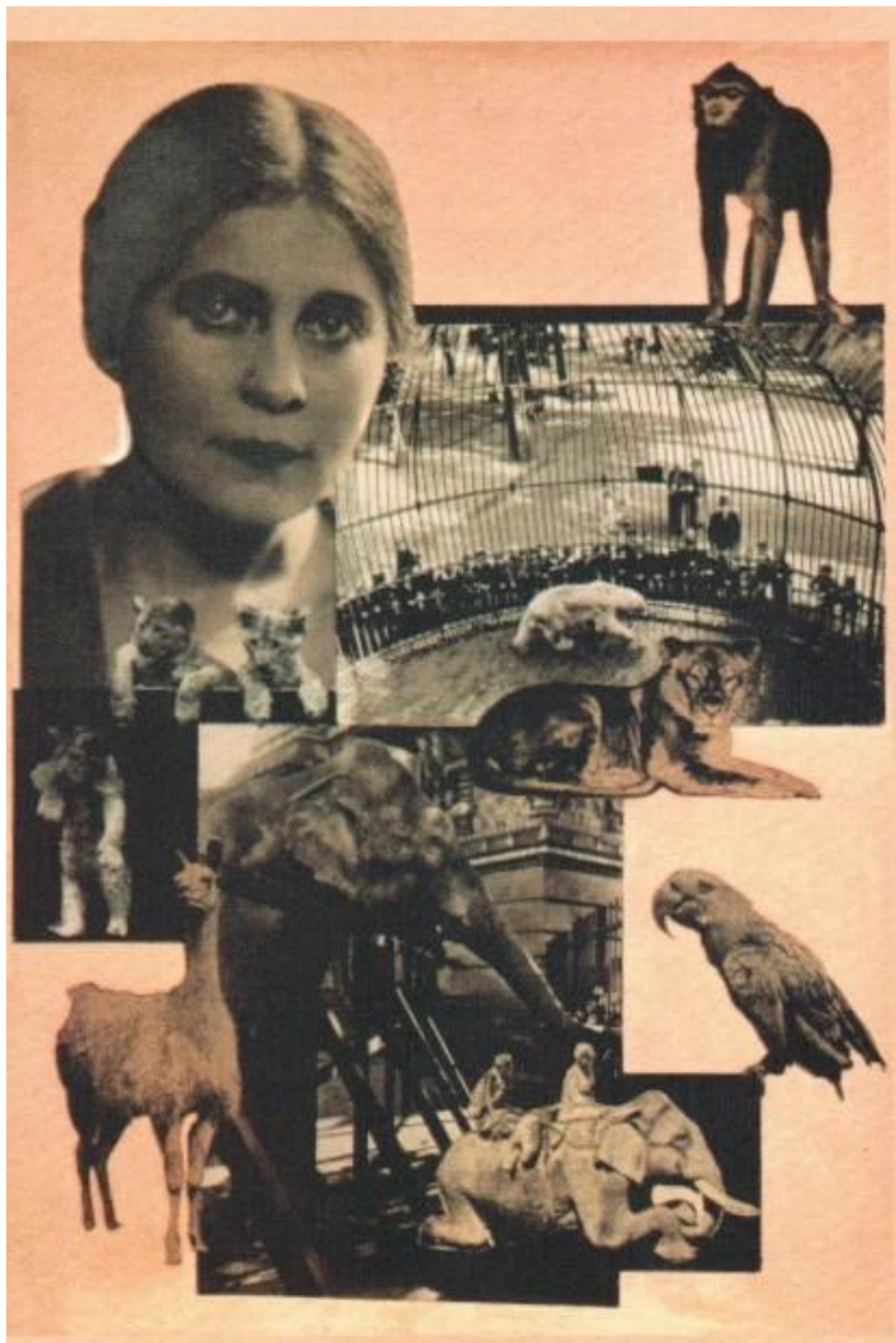

... и она - она зверей любила - тоже ступит в сад...

... ela - que amava os animais - também entrará no zoológico... 
Variantes não publicadas das fotomontagens (sem título):

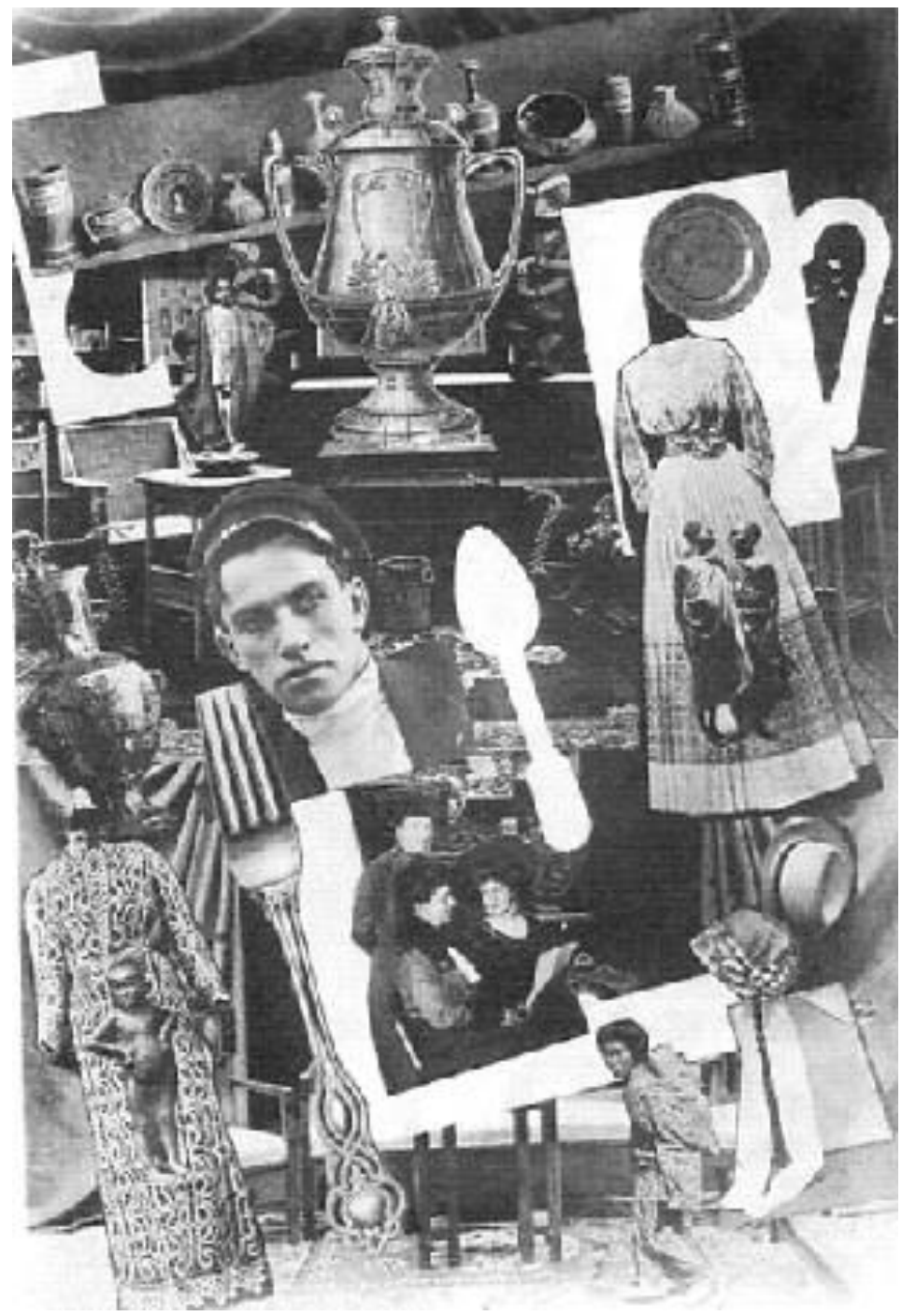




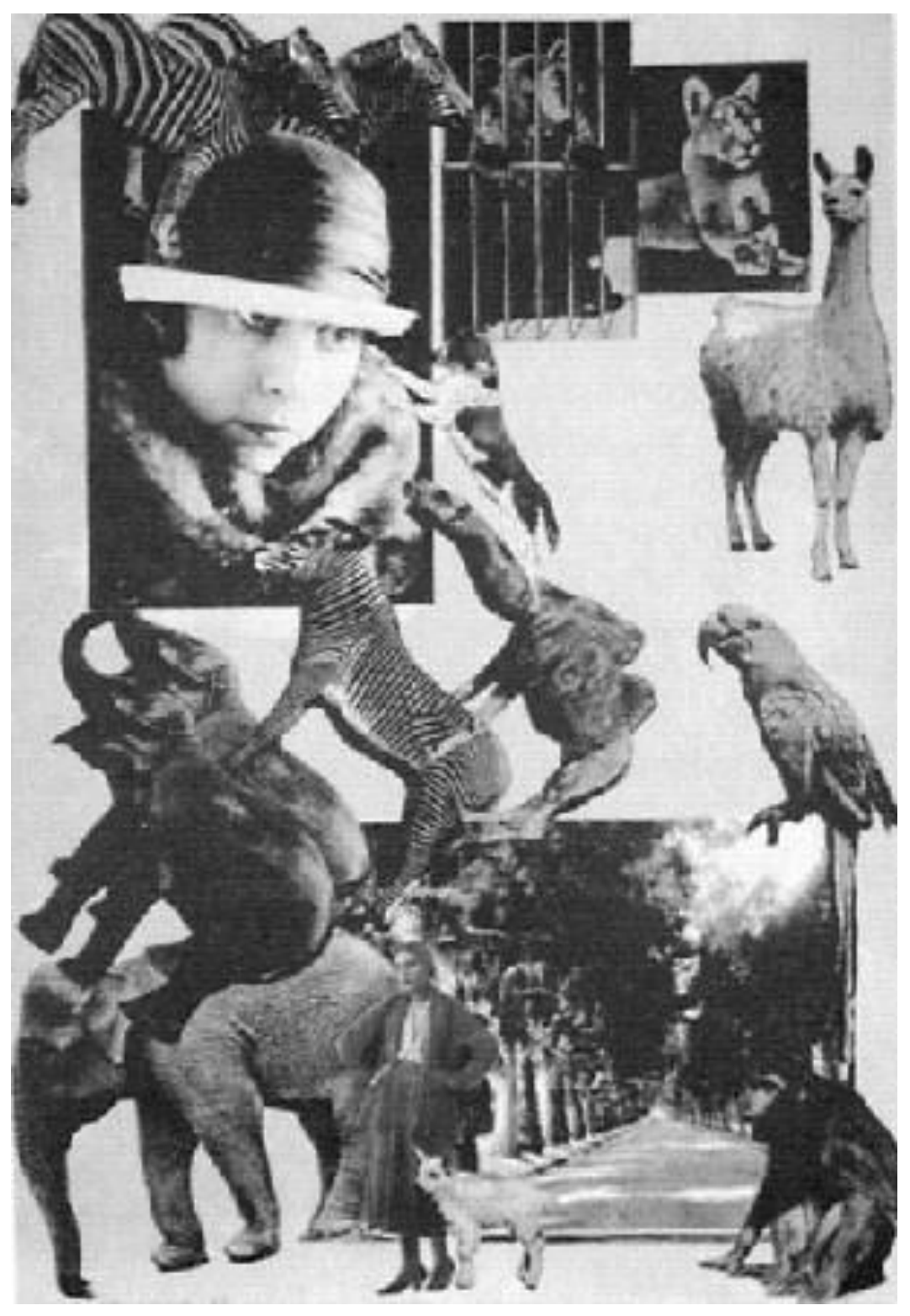




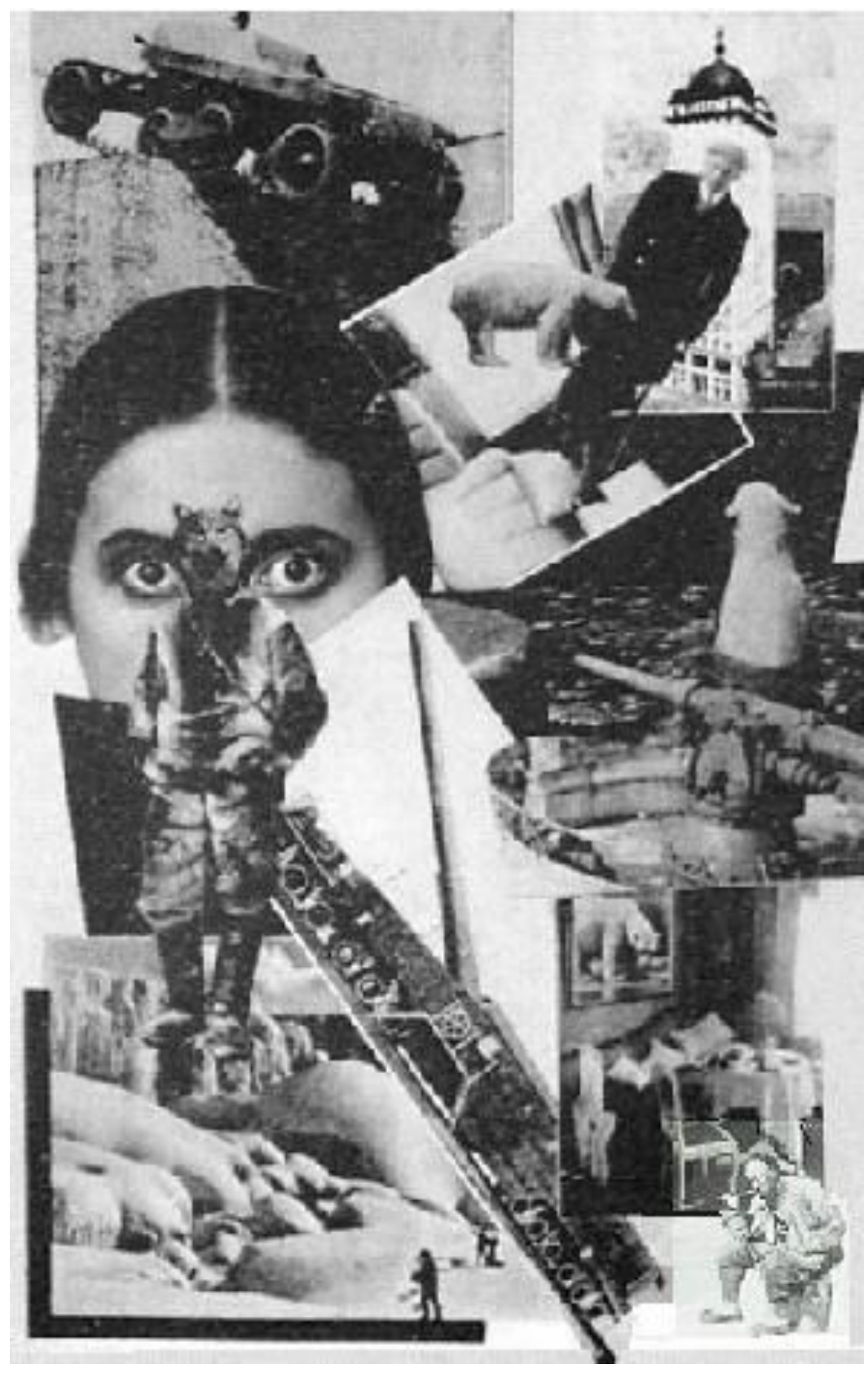

Fonte das fotomontagens: http://zorkadan.ru/razdel5/r5deviataia/r5deviattret.html, acesso em 28 de dezembro de 2014. 